LARISSA CARDILLO AFONSO

PRODUÇÃO DE CELULASES POR CULTIVO EM ESTADO SÓLIDO E APLICAÇÃO NA HIDRÓLISE DE BAGAÇO DE CANA-DE-AÇÚCAR 
LARISSA CARDILLO AFONSO

\title{
PRODUÇÃO DE CELULASES POR CULTIVO EM ESTADO SÓLIDO E APLICAÇÃO NA HIDRÓLISE DE BAGAÇO DE CANA-DE-AÇÚCAR
}

\author{
Dissertação apresentada à Escola \\ Politécnica da Universidade de São \\ Paulo para obtenção do título de \\ Mestre em Engenharia
}

São Paulo

2012 


\title{
PRODUÇÃO DE CELULASES POR CULTIVO EM ESTADO SÓLIDO E APLICAÇÃO NA HIDRÓLISE DE BAGAÇO DE CANA-DE-AÇÚCAR
}

\author{
Dissertação apresentada à Escola \\ Politécnica da Universidade de São \\ Paulo para obtenção do título de \\ Mestre em Engenharia \\ Área de Concentração: \\ Engenharia Química \\ Orientador: \\ Prof ${ }^{a}$. Livre-Docente Beatriz Vahan \\ Kilikian
}

São Paulo

2012 


\section{FICHA CATALOGRÁFICA}

\section{Afonso, Larissa Cardillo}

Produção de celulases por cultivo em estado sólido e aplicação na hidrólise de bagaço de cana-de-açúcar / L.C. Afonso. -São Paulo, 2012.

$119 \mathrm{p}$.

Dissertação (Mestrado) - Escola Politécnica da Universidade de São Paulo. Departamento de Engenharia Química.

1. Cana-de-açúcar 2. Bagaços 3. Soja 4. Celulase 5. Cultivo Em estado sólido 6. Myceliophthora I. Universidade de São PauIo. Escola Politécnica. Departamento de Engenharia Química II. t. 


\section{DEDICATÓRIA}

Aos meus pais e a minha avó. 


\section{AGRADECIMENTOS}

À Prof ${ }^{\mathrm{a}}$. Livre-Docente Beatriz Vahan Kilikian, pela orientação, incentivo, dedicação e amizade.

Aos meus pais, irmãos e a minha querida avó pelo carinho, amor, compreensão, paciência e apoio durante a realização desse trabalho.

À minha amiga Paula por estar sempre ao meu lado, trazendo alegria, boas risadas e força.

Ao meu amigo Bruno pela ajuda em todos os momentos e pela amizade.

Aos funcionários do GEnBio, Orlinda, Andréa e Válter pela colaboração e amizade.

À lara, Mariana, Felipe e todos os meus colegas do GEnBio.

À Coordenação de Aperfeiçoamento de Pessoal de Nível Superior (CAPES) pela concessão de bolsa.

A todas as pessoas e instituições que de alguma forma contribuíram para realização desse trabalho, os meus sinceros agradecimentos. 
The man who has ceased to learn ought not be allowed to wander around loose in these dangerous days.

- M.M. Coady 


\section{RESUMO}

São objetivos deste trabalho: (1) avaliar a produção de celulases pelo fungo termofílico Myceliophthora sp. M77, isolado no âmbito do programa BIOTA-FAPESP, cultivando-o em meios compostos por bagaço de cana-de-açúcar $(B)$ e farelo de trigo (T) ou farelo de soja (S), portanto, cultivos em estado sólido; (2) avaliar a eficácia das enzimas na hidrólise de bagaço de cana-de-açúcar e celulose cristalina. Nos cultivos em frascos Erlenmeyer, o maior valor de concentração de celulases foi obtido em meio SB (10:90) (porcentagem em massa) com 80\% de umidade inicial, 10,3 FPU.gms ${ }^{-1}$ após cinco dias de cultivo, valor este $120 \%$ superior ao valor de $4,8 \mathrm{U}_{\mathrm{gms}}{ }^{-1}$, que foi a maior concentração de celulases registrada no cultivo em meio TB $(20: 80)$ com $60 \%$ de umidade inicial. $\mathrm{O}$ uso de aeração forçada no cultivo de Myceliophthora sp. M77 em meio SB (10:90) com $80 \%$ de umidade inicial, em reator de leito fixo, resultou aumento de $30 \%$ na concentração de celulase e na máxima produtividade em relação aos cultivos em frasco Erlenmeyer. Ensaios de hidrólise nas temperaturas de $50^{\circ} \mathrm{C}, 60^{\circ} \mathrm{C} \mathrm{e}$ $70^{\circ} \mathrm{C}$ foram realizados para determinação da melhor temperatura de ação das celulases produzidas pelo fungo Myceliophthora sp. M77. Utilizou-se extrato obtido a partir do cultivo de Myceliophthora sp. M77 em meio SB (10:90) com umidade inicial de 60\% a $45^{\circ} \mathrm{C}$ por 3 dias. Após $48 \mathrm{~h}$ de hidrólise de bagaço de cana-de-açúcar pré-tratado por explosão a vapor, a conversão de celulose a glicose foi de $15 \%$ para $\mathrm{T}=50^{\circ} \mathrm{C}, 8 \%$ para $\mathrm{T}=60^{\circ} \mathrm{C}$ e $1,5 \%$ para $\mathrm{T}=70^{\circ} \mathrm{C}$. Os resultados indicam que pode ocorrer desnaturação térmica a $60^{\circ} \mathrm{C}$ e $70^{\circ} \mathrm{C}$ para períodos superiores a $6 \mathrm{~h}$ e $2 \mathrm{~h}$ de hidrólise, respectivamente. Ensaios de hidrólise de bagaço de cana-de-açúcar pré-tratado por explosão a vapor, a $50^{\circ} \mathrm{C}$, com adição de $10 \mathrm{FPU} \mathrm{gms}^{-1}$ de celulases produzidas por Myceliopthora sp. M77 em meio SB (10:90) resultaram conversão de celulose a glicose $50 \%$ maior do que para o ensaio de hidrólise nas mesmas condições com enzimas produzidas em meio TB (40:60), indicando que a composição dos extratos enzimáticos produzidos em meio TB e SB são diferentes. A concentração inicial de glicose de $1 \mathrm{~g} \cdot \mathrm{L}^{-1}$ no extrato produzido em meio TB pode ter inibido a ação da enzima $\beta$-glicosidade. Já os extratos produzidos em meio SB apresentaram concentrações de glicose inicial inferiores a $0,15 \mathrm{~g} \cdot \mathrm{L}^{-1}$. Ensaios de hidrólise com enzimas aderidas ao meio de cultura sólido foram realizados com a finalidade de avaliar essa metodologia em comparação à hidrólise usual com enzimas extraídas do meio. Após $48 \mathrm{~h}$, as conversões de celulose a glicose das hidrólises de celulose cristalina ou bagaço de cana-de-açúcar pré-tratado por explosão à vapor com enzimas aderidas ao meio de cultura foram ou superiores ou iguais àquelas obtidas nas hidrólises com enzimas extraídas do meio de cultura. Esse resultado mostra que existe a possibilidade de aplicação direta da enzima não extraída do meio de cultura sólido, com consequente redução do custo do processo de hidrólise do material celulósico para liberação de açúcares fermentescíveis.

Palavras-chave: Celulase. Cultivo em Estado Sólido. Myceliophthora sp.. Farelo de soja. Bagaço de cana-de-açúcar. 


\begin{abstract}
The objectives of this study are: (1) to evaluate the production of cellulases by a thermophilic fungus, Myceliophthora sp. M77, isolated by the BIOTA-FAPESP program. The microorganism was cultivated in media composed by sugarcane bagasse (B) and wheat bran (T) or soybean meal (S), thus, solid state cultivation; (2) to evaluate the effectiveness of these enzymes in the hydrolysis of sugarcane bagasse and crystalline cellulose. The highest cellulases concentration in Erlenmeyer flasks cultures was achieved in medium SB (10:90) (w/w) with initial moisture of $80 \%, 10.3 \mathrm{FPU}^{-g d m^{-1}}$ after five days of cultivation, a value $120 \%$ higher than $4.8 \mathrm{U} . \mathrm{gdm}^{-1}$, which was the highest recorded cellulases concentration in culture using TB $(20: 80)$ with $60 \%$ of initial moisture. Applying forced aeration in the cultivation of Myceliophthora sp. M77 in medium SB (10:90) with $80 \%$ initial moisture, in fixed bed reactor, cellulases concentration and maximum productivity raised $30 \%$ relative to cultivation in Erlenmeyer flask. Hydrolysis assays at temperatures of $50^{\circ} \mathrm{C}, 60^{\circ} \mathrm{C}$ and $70^{\circ} \mathrm{C}$ were performed to evaluate the optimal temperature for application of cellulases produced by the fungus Myceliophthora sp. M77, since it is a thermophilic fungus. It was used the enzymatic extract produced from cultures in medium SB (10:90) with $60 \%$ initial moisture, at $50^{\circ} \mathrm{C}$, for three days. After $48 \mathrm{~h}$ of hydrolysis of sugarcane bagasse pretreated by steam explosion, the conversion of cellulose to glucose was $15 \%$ for $\mathrm{T}=50{ }^{\circ} \mathrm{C}, 8 \%$ for $\mathrm{T}=60$ ${ }^{\circ} \mathrm{C}$ and $1.5 \% \mathrm{~T}=70{ }^{\circ} \mathrm{C}$. These results indicated that thermal denaturation may occur in hydrolysis at $60^{\circ} \mathrm{C}$ and $70^{\circ} \mathrm{C}$ for periods longer of $6 \mathrm{~h}$ and $2 \mathrm{~h}$, respectively. Hydrolysis of sugarcane bagasse pretreated by steam explosion at $50^{\circ} \mathrm{C}$ with addition of $10 \mathrm{FPU} . g \mathrm{dm}^{-}$ ${ }^{1}$ of cellulases produced by Myceliopthora sp. M77 in medium TB (40:60), resulted in conversion of cellulose to glucose $50 \%$ lower than hydrolysis with enzymes produced in medium SB (10:90), under the same conditions, indicating that the composition of enzyme extracts produced in TB and SB medium are different. The initial glucose concentration of $1 \mathrm{~g} . \mathrm{L}^{-1}$ in the enzyme extract produced in TB medium can inhibit the action of the enzyme $\beta$-glucosidade. On the other hand, initial glucose concentration in the extract produced in medium SB was lower than $0.15 \mathrm{~g} . \mathrm{L}^{-1}$. Hydrolysis using enzymes adhered to the solid culture medium were performed in order to compare this method to the usual hydrolysis with enzymes extracted from the medium. After $48 \mathrm{~h}$, the cellulose conversion to glucose in the hydrolysis of sugarcane bagasse pretreated by steam explosion or crystalline cellulose were either greater than or equal to those obtained by hydrolysis with enzymes extracted from the culture medium. This result shows that there is the possibility of direct application of the enzyme still adhered to the solid culture medium, with consequent reduction of the process cost of cellulosic materials hydrolysis to release fermentable sugars.
\end{abstract}

Keywords: Cellulase. Solid State Cultivation. Myceliophthora sp.. Soybean meal. Sugarcane bagasse. 


\section{LISTA DE ILUSTRAÇÕES}

Figura 1 - Sistema básico de coluna de Raimbault. ............................................26

Figura 2 - Estrutura de um fragmento da celulose (FENGEL e WEGENER, 1989) .......33

Figura 3 - Estrutura de uma fibrila elementar da celulose (CHAGAS, 2007) ..................34

Figura 4 - Complexo lignocelulósico da parede celular vegetal.....................................34

Figura 5 - Esquema do pré-tratamento do material lignocelulósico................................36

Figura 6 - Esquema dos ensaios em coluna de Raimbault .........................................45

Figura 7 - Esquema dos ensaios de hidrólise com e sem extração de enzimas

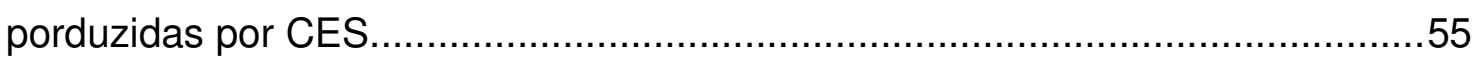

Figura 8 - Concentração de celulases ao longo do tempo para cultivos de

Myceliophthora sp. M77, em frascos Erlenmeyer, em meios de cultura

constituídos de TB (10:90) 60\%, TB (20:80) 60\%, SB (10:90) 60\%, SB (20:80)

$60 \%$ e SB $(10: 90) 80 \%$.

Figura 9 - Produtividade em celulase em relação à máxima concentração de celulases nos cultivos de Myceliophthora sp. M77 em meios de cultura constituídos de TB (20:80), TB (10:90), SB (20:80) e SB (10:90), todos com umidade inicial de $60 \%$, e meio SB (10:90), com umidade inicial de $80 \%$. 60

Figura 10 - Produtividade em celulase ao longo do tempo para cultivos de

Myceliophthora sp. M77, em frascos Erlenmeyer, em meios de cultura constituídos de TB (10:90) 60\%, TB (20:80) 60\%, SB (10:90) 60\%, SB (20:80) $60 \%$ e SB $(10: 90) 80 \%$.

Figura 11 - Concentração de endoglicanase e de xilanase ao longo do tempo de cultivo de Myceliopthora sp. M77 em meio SB (10:90) com umidade inicial de $80 \%$....66

Figura 12 - Velocidades de consumo de $\mathrm{O}_{2}\left(\mathrm{OUR}, \mathrm{mmol}_{2} \cdot \mathrm{h}^{-1}\right)$ e produção de $\mathrm{CO}_{2}$ (CER, mmol CO $\mathrm{CH}^{-1}$ ) em função do tempo de cultivo de Myceliophthora sp. M77 em reator de leito fixo, meio SB (10:90) com umidade inicial de $80 \%$ para (a) Ensaio 1 e (b) Ensaio 2. 
Figura 13 - Concentração de celulases $\left(\mathrm{C}_{\mathrm{FPA}}, \mathrm{FPU} \cdot \mathrm{gms}^{-1}\right)$ em função do tempo de cultivo de Myceliophthora sp. M77 em reator de leito fixo, meio SB (10:90) com umidade inicial de $80 \%$ para os ensaios 1 e 2

Figura 14 - Umidade média (base úmida) do meio de cultura em função do tempo de cultivo em reator de leito fixo de Myceliophthora sp. M77 em meio SB (10:90) com umidade inicial de $80 \%$, para os ensaios 1 e 2 .

Figura 15 - Amostras dos cultivos de coluna para $t=0$ e $t=120 \mathrm{~h}$ 69

Figura 16 - Conversão de celulose a glicose (\%) na hidrólise de bagaço pré-tratado por explosão a vapor, com enzimas produzidas por CES, sem suplementação de xilanase e $\beta$-glicosidase (concentração de sólidos 1\% e adição de $10 \mathrm{FPU} / \mathrm{gms}$ bagaço).

Figura 17 - Atividade em 'Filter Paper' durante os ensaios a $50^{\circ} \mathrm{C}$ e $60^{\circ} \mathrm{C}$ de hidrólise de bagaço de cana-de-açúcar pré tratado por explosão a vapor com extrato enzimático produzido por CES de Myceliophthora sp. M77 em meio SB (10:90) com $60 \%$ de umidade inicial.

Figura 18 - Conversão de celulose a glicose em função do tempo reacional para reação de HEx e HAd de celulose cristalina, com e sem suplementação de $\beta$-glicosidase

Figura 19 - Conversão de celulose a glicose em função do tempo reacional para reação de HEx e HAd do substrato bagaço de cana-de-açúcar pré-tratado por explosão à vapor, com e sem suplementação de $\beta$-glicosidase. .78 


\section{LISTA DE TABELAS}

Tabela 1 - Composição química de diferentes materiais lignocelulósicos (\% de massa seca) (LEE, 1997). 20

Tabela 2 - Produção de celulases por fungos cultivados em substratos lignocelulósicos (adaptado de CAMASSOLA e DILLON, 2007). 32

Tabela 3 - Processos de pré-tratamento de biomassa lignocelulósica (TAHERZADEH e KARIMI, 2008). 37

Tabela 4 - Atividade específica das enzimas adicionadas nos ensaios de hidrólise de bagaço de cana-de-açúcar pré-tratado. 53

Tabela 5 - Conversão de celulose em glicose em 48h de hidrólise de bagaço de cana: não tratado $(A)$, pré-tratados por radiação ionizante em 30kGy (B), 70 kGy (C) e 150kGy (D) e pré-tratado por explosão a vapor (E). 71

Tabela 6 - Atividade de Filter Paper após 48h de reação de hidrólise de celulose cristalina 80 


\section{LISTA DE ABREVIATURAS E SIGLAS}

\begin{tabular}{|c|c|}
\hline$a_{w}$ & Atividade de água \\
\hline B & Bagaço de cana-de-açúcar \\
\hline CER & Velocidade de produção de $\mathrm{CO}_{2}$ \\
\hline CES & Cultivo em estado sólido \\
\hline $\mathrm{C}_{\mathrm{FPA}}$ & Concentração de celulases \\
\hline CS & Cultivo Submerso \\
\hline DNS & Ácido dinitrossalicílico \\
\hline FP & Filter Paper; \\
\hline FPA & Atividade de Filter Paper (Atividade de papel de filtro) \\
\hline GEnBio & $\begin{array}{l}\text { Grupo de Engenharia de Bioprocessos do Departamento de Engenharia } \\
\text { Química da Escola Politécnica da USP }\end{array}$ \\
\hline HAd & Hidrólise com enzimas aderidas ao meio de cultura sólido \\
\hline HEX & Hidrólise com enzimas extraídas do meio de cultura sólido \\
\hline $\mathbf{m}_{\circ}$ & Coeficiente de respiração para manutenção das células \\
\hline OUR & Velocidade de consumo de $\mathrm{O}_{2}$ \\
\hline $\mathbf{P}_{\mathbf{R}}$ & Produtividade em celulases \\
\hline $\mathbf{S}$ & Farelo de soja \\
\hline SSF & $\begin{array}{l}\text { Sacarificação e Fermentação Simultâneas (Simultaneous Saccharification } \\
\text { and Fermentation) }\end{array}$ \\
\hline $\mathbf{T}$ & Farelo de trigo \\
\hline $\mathbf{U}$ & $\begin{array}{l}\text { Unidade de atividade enzimática ( } 1 U \text { é a quantidade de enzima que } \\
\text { catalisa } 1 \mu \mathrm{mol} \text { de produto por minuto) }\end{array}$ \\
\hline UNICA & União das Indústrias de Cana-de-Açúcar do Brasil \\
\hline $\mathbf{X}_{\mathbf{c}}$ & Massa celular \\
\hline $\mathbf{Y}_{\mathbf{X} / \mathrm{CO} 2}$ & Fator de conversão de $\mathrm{CO}_{2}$ à células \\
\hline $\mathbf{Y}_{\mathbf{X} / 0}$ & Fator de conversão de $\mathrm{O}_{2}$ à células \\
\hline
\end{tabular}




\section{SUMÁRIO}

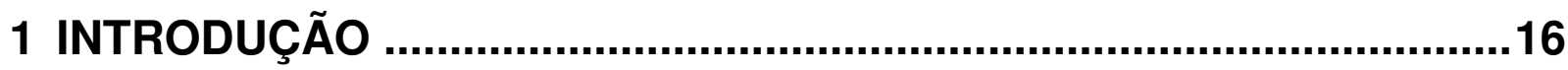

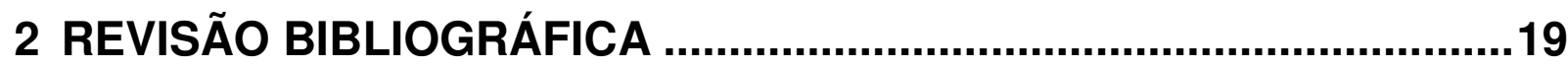

2.1 CULTIVO EM ESTADO SÓLIDO ………........................................................19

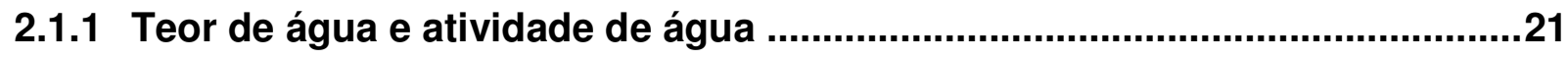

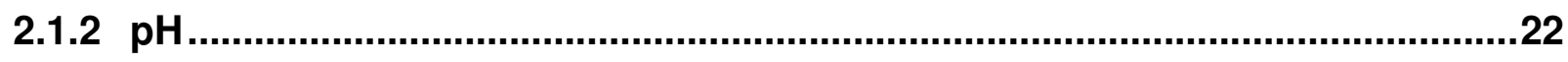

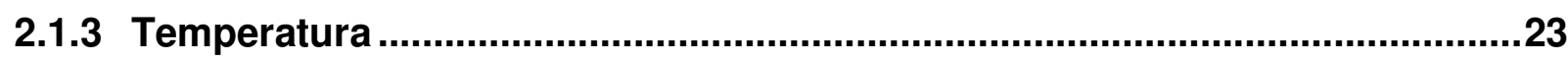

2.2 REATORES PARA CES E AMPLIAÇÃO DE ESCALA …...................................24

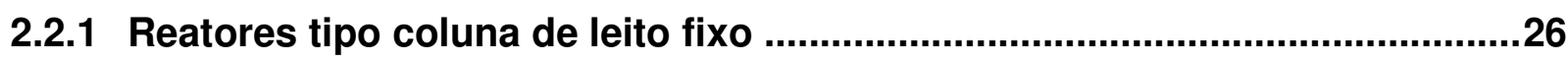

2.3 ESTIMATIVA DE BIOMASSA EM CES .......................................................27

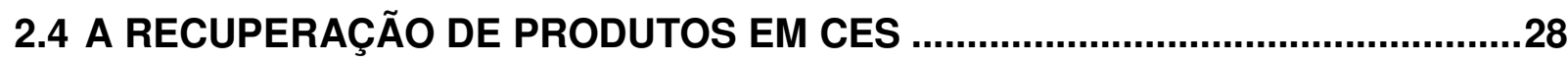

2.5 PRODUÇÃO DE CELULASES POR CES …….................................................

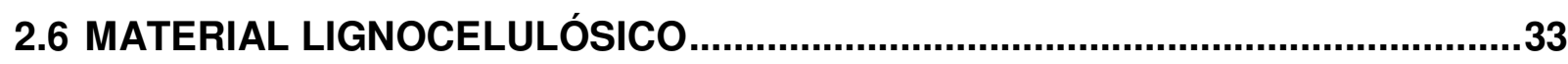

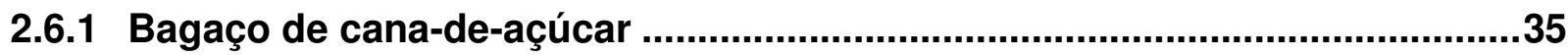

2.7 PRÉ-TRATAMENTO DO MATERIAL LIGNOCELULÓSICO...................................36

2.7.1 Pré-tratamento por radiação ionizante ……...................................................38

2.7.2 Pré-tratamento por explosão à vapor .........................................................38

2.8 HIDRÓLISE ENZIMÁTICA DA BIOMASSA LIGNOCELULÓSICA ......................39

2.8.1 Concentração de sólidos .............................................................................

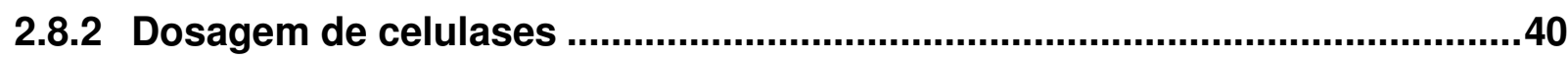

2.8.3 Inibição pelos produtos finais da reação de hidrólise ..................................41

3 MATERIAIS E MÉTODOS ...............................................................42

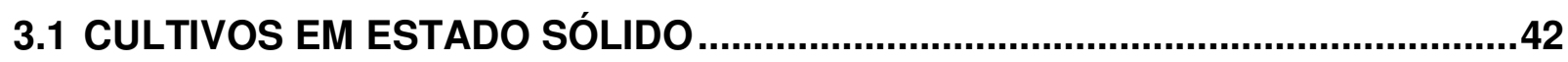

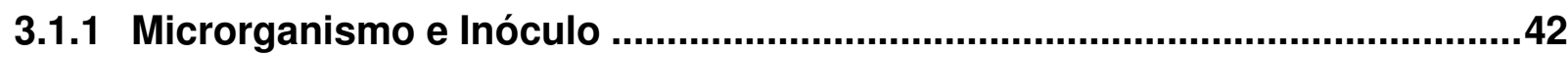

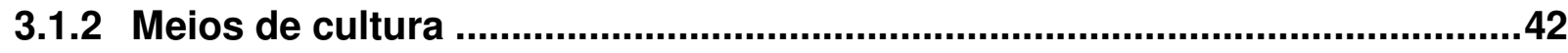

3.1.3 Soluções Utilizadas ..........................................................................................43

3.1.4 Cultivo em estado sólido em Frasco Erlenmeyer ..........................................43

3.1.5 Cultivo em estado sólido em reator tipo coluna de Raimbault.......................44 


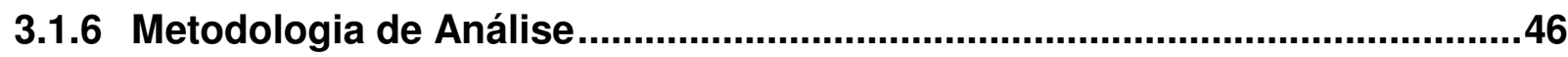

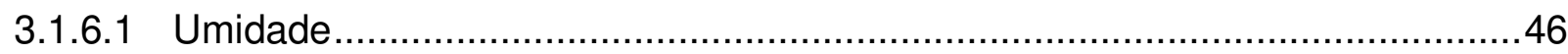

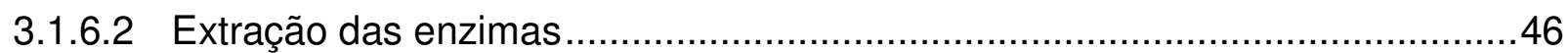

3.1.6.3 Atividades enzimáticas e Produtividade da enzima ........................................46

3.1.6.4 Curva padrão de absorbância ................................................................

3.1.6.5 Atividade de Filter Paper .................................................................... 48

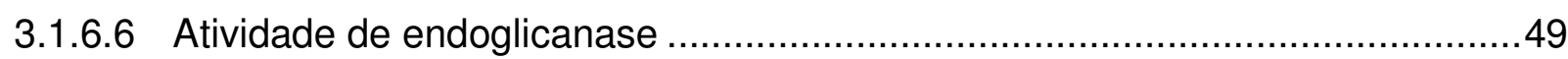

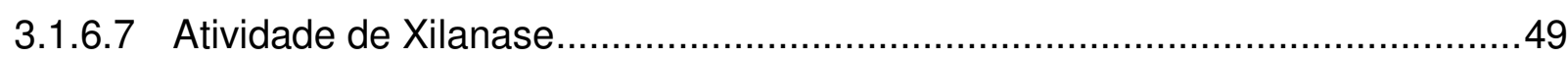

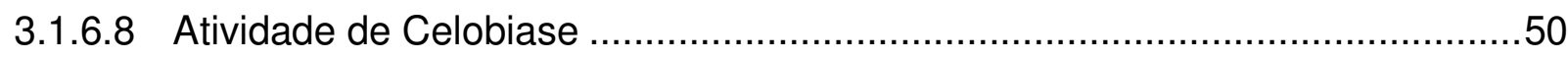

3.1.6.9 Análise do gás de saída dos reatores tipo coluna de Raimbault.....................50

3.2 ENSAIOS DE HIDRÓLISE COM ENZIMAS PRODUZIDAS POR CES .................51

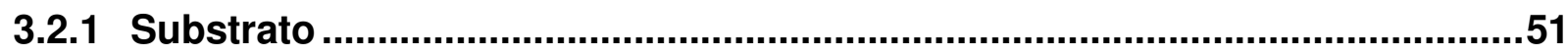

3.2.2 Ensaios de Hidrólise...................................................................................

3.2.3 Ensaios de Hidrólise com bagaço submetido a diferentes pré-tratamentos52

3.2.4 Hidrólise enzimática a diferentes temperaturas .........................................53

3.2.5 Hidrólise enzimática com ou sem extração de enzimas ...............................53

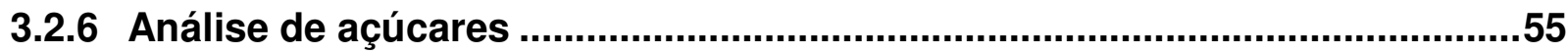

3.2.7 Cálculo de conversão de celulose em glicose ............................................56

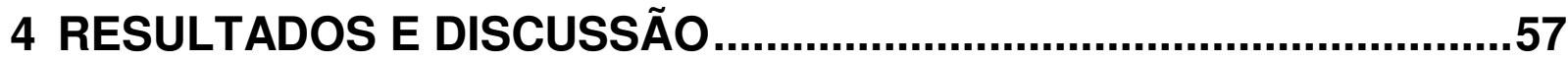

4.1 PRODUÇÃO DE CELULASES POR CULTIVO EM ESTADO SÓLIDO (CES) .......57

4.1.1 Avaliação de meios de cultura na produção de celulases por

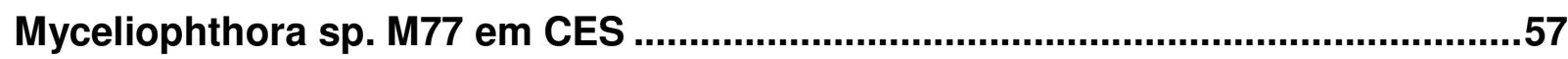

4.1.2 Cultivos de Myceliophthora sp. M77 em coluna de Raimbault.....................64

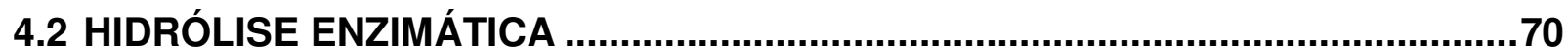

4.2.1 Hidrólise enzimática de bagaço de cana-de-açúcar pré-tratado ...................70

4.2.2 Hidrólise enzimática a diferentes temperaturas ...........................................73

4.2.3 Hidrólise com e sem extração de enzimas de CES........................................76

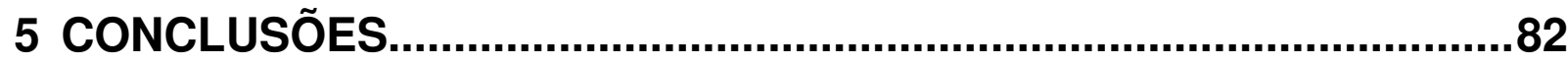

5.1 PRODUÇÃO DE CELULASES POR CULTIVO EM ESTADO SÓLIDO (CES) ......82

5.1.1 Avaliação de meios de cultura na produção de celulases por Myceliophthora sp. M77 em CES ......................................................................... 82 
5.1.2 Cultivos de Myceliophthora sp. M77 em coluna de Raimbault .....................82

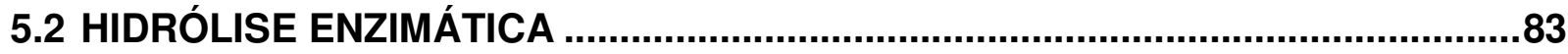

5.2.1 Hidrólise enzimática de bagaço de cana-de-açúcar pré-tratado ....................83

5.2.2 Hidrólise enzimática a diferentes temperaturas .........................................83

5.2.3 Hidrólise com e sem extração de enzimas produzidas por CES ....................84

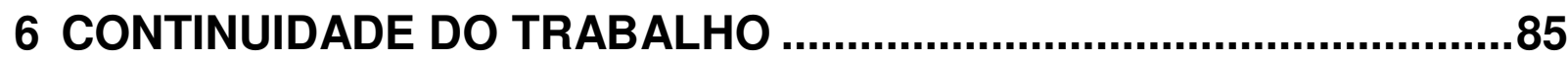

REFERÊNCIAS BIBLIOGRÁFICAS ....................................................86

APÊNDICE A - ARTIGO SUBMETIDO PARA PUBLICAÇÂO..................99 


\section{INTRODUÇÃO}

Anualmente, milhares de toneladas de resíduos agrícolas são gerados no processamento de matérias-primas de diversas culturas. Atualmente, parte desses materiais não tem aplicação específica e gera problemas ambientais de contaminação provenientes de práticas como queima a céu aberto, abandono ou enterro desses resíduos pelos agricultores.

Em sua maioria, os resíduos agrícolas são materiais lignocelulósicos, ou seja, complexos orgânicos de carbono formados principalmente por três componentes: celulose, hemicelulose e lignina (BADHAN et al., 2007). Na natureza, os materiais lignocelulósicos são utilizados como fonte de carbono por inúmeras bactérias e fungos, que conseguem hidrolisar a celulose desses materiais pela ação de enzimas denominadas celulases (CEN e XIA, 1999). As celulases têm ganhado muita atenção de pesquisadores por sua aplicação na hidrólise de resíduos agrícolas visando à liberação da glicose contida na celulose (OLSSON e HAHN-HAGERDAL, 1996).

Atualmente, as celulases são aplicadas na indústria de papel e celulose para branqueamento da polpa de celulose, na indústria têxtil produzindo a aparência "lavada" de jeans e tornando tecidos mais lisos e macios e na indústria de alimentos, por exemplo, na produção de sucos de frutas, liquefazendo o tecido vegetal e permitindo a extração de pigmentos do fruto (MUSSATTO et al., 2007).

A busca por celulases eficientes e alta produtividade na síntese enzimática microbiana são fatores essenciais para aplicação comercial dessas enzimas (LONSANE et al., 1992).

Uma alternativa à produção convencional de celulases em cultivos microbianos submersos é o cultivo em estado sólido (CES), denominado frequentemente de fermentação em estado sólido, sendo este um processo atraente devido à utilização de resíduos da agroindústria como substrato e devido à obtenção de produtividades maiores em comparação ao cultivo submerso (CS), fatores que contribuem para redução do custo de produção das celulases (CEN e XIA, 1999; PANDEY et al., 1999). 
Um dos principais resíduos agrícolas brasileiros é o bagaço de cana-de-açúcar oriundo do processamento da cana-de-açúcar para produção de etanol e açúcar. De acordo com a União das Indústrias de Cana-de-açúcar do Brasil (UNICA), na safra de 2010/2011, o Brasil processou cerca de 557 milhões de toneladas de cana-de-açúcar, produzindo cerca de 160 milhões de toneladas de bagaço. Deste total de bagaço, cerca de $90 \%$ é queimado em caldeiras nas próprias usinas para geração de energia, restando assim cerca de $10 \%$ desse material disponível para outros usos.

Além da utilização desse bagaço residual como fonte de carbono para produção de diversos metabólitos por CES, há também forte atrativo em hidrolisá-lo para solubilização de seus açúcares e posterior transformação dos mesmos em etanol (etanol de segunda geração - etanol 2G), por via fermentativa, aumentando assim a produção de etanol combustível, sem o correspondente aumento da área cultivada. A inserção do bagaço de cana-de-açúcar como substrato na produção de etanol, juntamente com a sacarose do caldo, tende a reduzir o custo do etanol $2 \mathrm{G}$ e reduzir a competição entre biocombustíveis e alimentos (MARQUES, 2009).

A presente dissertação de mestrado insere-se em dois projetos do Grupo de Engenharia de Bioprocessos do Departamento de Engenharia Química da EPUSP (GEnBio). O primeiro projeto denomina-se "PRODUÇÃO DE ETANOL POR HIDRÓLISE ENZIMÁTICA DA BIOMASSA DA CANA-DE-AÇÚCAR" (Rede BIOETANOL), firmado através do Convênio FINEP 01.06.0047.00 n. 4183/05 Encomenda Ação Transversal, com a Coordenação Geral do Prof. Rogério Cezar de Cerqueira Leite e a participação de dezenas de pesquisadores de várias instituições de ensino e pesquisa do país. 0 objetivo geral é o desenvolvimento de tecnologia, utilizando hidrólise enzimática, para a transformação da biomassa (bagaço e palha) da cana-de-açúcar em álcool combustível. A Prof $^{a}$ Beatriz Vahan Kilikian participa deste projeto integrando o grupo de "Desenvolvimento de bioprocessos para produção de enzimas celulolíticas a serem utilizadas na hidrólise de bagaço e palha".

O segundo projeto trata-se de um Auxílio à Pesquisa Individual apoiado pela FAPESP (Processo N 06/51085-2), denominado "Estudo da Ampliação de Escala em Fermentação Semi-Sólida Aplicado ao Cultivo de Monascus sp. em Biorreator". A despeito de o projeto considerar o cultivo de Monascus sp., o objetivo maior é 
desenvolver estudos de ampliação de escala no cultivo de microrganismos em meio sólido, em reatores, situação na qual se encaixa a questão da produção das celulases através de cultivos em estado sólido.

Dos projetos acima mencionados, foram realizadas 3 Iniciações Científicas, 2 trabalhos de TCC, uma supervisão de pós doutoramento e 2 mestrados. Microrganismos tais como Trichoderma reesei Rut-C30, Trichoderma reesei QM9414 e Trichoderma harzianum, já foram analisados quanto à produtividade em celulases. Dentro desse contexto, o objetivo desse trabalho foi avaliar a produção de celulases por um microrganismo recém isolado, Myceliophthora sp. M77, em diferentes substratos e analisar a aplicação de suas enzimas na hidrólise de bagaço de cana-de-açúcar prétratado. 


\section{REVISÃO BIBLIOGRÁFICA}

\subsection{CULTIVO EM ESTADO SÓLIDO}

No cultivo em estado sólido (CES) microrganismos crescem em meio sólido sem a presença de água livre. A umidade necessária para o crescimento microbiano encontra-se absorvida, ou complexada no meio (CANNEL e MOO YOUNG, 1980).

Dois tipos de CES podem ser definidos em função da natureza da fase sólida. $O$ mais comum é o cultivo em meio sólido natural e o menos utilizado é aquele que envolve o cultivo em um suporte inerte impregnado com meio de cultura líquido (OOIJKAAS et al., 2000).

Historicamente é creditado ao CES o início do uso das técnicas de cultivo de microrganismos para produção de metabólitos. No entanto, em meados de 1940 ocorreu uma redução drástica dos estudos envolvendo CES, principalmente devido ao incentivo para a produção da penicilina por Cultivo Submerso (CS), durante a Segunda Guerra Mundial. Somente a partir dos anos 70 voltou-se a dar atenção para o CES, devido à publicação de trabalhos referentes à produção de ração animal enriquecida com proteínas que envolviam a utilização de resíduos agroindustriais, oferecendo assim a oportunidade de desenvolvimento de um processo para valorização desses resíduos. Desde então, houve um constante aumento no número de trabalhos reportados utilizando-se CES, sendo que a grande explosão ocorreu a partir dos anos 90 (PANDEY, 2003). Existem várias publicações recentes descrevendo processos de CES que foram desenvolvidos utilizando resíduos para a produção de produtos tais como, etanol, proteínas, enzimas, ácidos orgânicos, aminoácidos, metabólitos secundários, etc (COUTO e SANROMÁN, 2006).

As principais vantagens do emprego de CES em relação ao CS incluem altas produtividades, uso de resíduos como substratos, baixo consumo energético, menor uso e descarte de água e condições de cultivo similares ao ambiente natural dos 
microrganismos, principalmente fungos (COUTO e SANROMÁN, 2006; KRISHNA, 2005; SINGHANIA et al., 2009).

Porém, o processo de CES também apresenta desvantagens, tais como: dificuldade de remoção do calor metabólico gerado pelo crescimento dos microrganismos; dificuldade de agitação resultando heterogeneidade do meio e, portanto, formação de gradientes de temperatura, umidade e concentração de metabólitos; dificuldades no controle do processo; dificuldade na determinação de crescimento microbiano e outros parâmetros de cultivo; dificuldade de ampliação de escala (KRISHNA, 2005).

O CES tem ganhado mais atenção devido à possibilidade do uso de resíduos agroindustriais, baratos e abundantes, como substrato. Materiais lignocelulósicos tais como, bagaço de cana-de-açúcar, palha de milho, palha de arroz, entre outros, são utilizados como fonte de carbono para o crescimento dos microrganismos. Já a fonte de nitrogênio inclui compostos inorgânicos, como uréia e $\left(\mathrm{NH}_{4}\right)_{2} \mathrm{SO}_{4}$, ou produtos naturais ricos em proteínas, como farelos (CEN e XIA, 1999). A Tabela 1 apresenta a composição química de alguns materiais lignocelulósicos utilizados no CES.

Tabela 1 - Composição química de diferentes materiais lignocelulósicos (\% de massa seca) (LEE, 1997).

\begin{tabular}{|c|c|c|c|c|c|}
\hline & $\begin{array}{l}\text { Palha de } \\
\text { Milho }\end{array}$ & $\begin{array}{c}\text { Palha de } \\
\text { trigo }\end{array}$ & $\begin{array}{c}\text { Palha de } \\
\text { arroz }\end{array}$ & $\begin{array}{c}\text { Casca de } \\
\text { arroz }\end{array}$ & $\begin{array}{c}\text { Bagaço de } \\
\text { cana }\end{array}$ \\
\hline \multicolumn{6}{|c|}{ Carboidratos (\% açúcar equivalente) } \\
\hline Glicose & 39,0 & 36,6 & 41,0 & 36,1 & 38,1 \\
\hline Manose & 0,3 & 0,8 & 1,8 & 3,0 & ND \\
\hline Galactose & 0,8 & 2,4 & 0,4 & 0,1 & 1,1 \\
\hline Xilose & 14,8 & 19,2 & 14,8 & 14,0 & 23,3 \\
\hline Arabinose & 3,2 & 2,4 & 4,5 & 2,6 & 2,5 \\
\hline \multicolumn{6}{|c|}{ Não-Carboidratos (\%) } \\
\hline Lignina & 15,1 & 14,5 & 9,9 & 19,4 & 18,4 \\
\hline Cinzas & 4,3 & 9,6 & 12,4 & 20,1 & 2,8 \\
\hline Proteína & 4,0 & 3,0 & ND & ND & 3,0 \\
\hline
\end{tabular}

ND: Não disponível 
O maior grupo de microrganismos utilizados em CES são fungos e bactérias, sendo os fungos filamentosos os melhores adaptados para CES. A capacidade dos fungos filamentosos de colonizar o substrato sólido pelo crescimento apical e penetrálo, dá-lhes vantagem considerável sobre as bactérias e leveduras, menos capazes de colonizar em substrato de baixa umidade (RAIMBAULT, 1998).

O modo básico de crescimento de fungos é uma combinação da extensão apical das pontas das hifas e da geração de novas pontas através da ramificação. Uma característica importante é que, embora a extensão ocorra apenas nas pontas, a frequência de ramificação faz com que o padrão da cinética de crescimento da biomassa seja exponencial, principalmente no início do crescimento vegetativo. As enzimas hidrolíticas são excretadas na ponta das hifas, sem grande diluição como no caso do CS, o que torna a ação dessas enzimas eficiente e permite a penetração do fungo na maioria dos substratos sólidos. A penetração aumenta a acessibilidade aos nutrientes disponíveis no meio sólido de cultura (RAIMBAULT, 1998).

Assim como nos CS, existem vários fatores que afetam os CES, e estes variam de processo para processo, dependendo do tipo de substrato, do microrganismo utilizado, e do tamanho de escala do processo. Entre esses fatores estão: tipo de inóculo, teor de água, $\mathrm{pH}$, temperatura, tamanho da partícula, aeração e agitação (PANDEY, 2003).

A descrição quantitativa da influência desses fatores sobre o crescimento microbiano é essencial para a modelagem e otimização dos cultivos em estado sólido. Alguns desses fatores são listados a seguir.

\subsubsection{Teor de água e atividade de água}

O teor de água do substrato tem um efeito significativo sobre a atividade fisiológica dos microrganismos e pode ser reconhecido como um fator chave nos cultivos em estado sólido. 
A limitação de água pode afetar os processos de germinação, esporulação e formação de metabólitos. Já o excesso de água reduz os espaços vazios assim como o volume de fase gasosa no interior do substrato, o que aumenta a resistência de transferência de massa de oxigênio e gás carbônico e a possibilidade de contaminação (CEN e XIA, 1999). Em geral, o teor de água nos processos de CES varia entre $50 \mathrm{e}$ $80 \%$ (base úmida).

Os CES são caracterizados pela ausência de água livre no meio de cultura. Água livre ocorre quando a saturação da matriz sólida é excedida. No entanto, o nível de umidade no qual ocorre água livre aparente varia consideravelmente entre substratos, dependendo de suas características de retenção de água (RAIMBAULT, 1998).

Em geral, as necessidades hídricas do microrganismo devem ser definidas em termos de atividade de água $\left(\mathrm{a}_{\mathrm{w}}\right)$ ao invés de teor de umidade do substrato sólido. A atividade de água é um parâmetro termodinâmico relacionado ao potencial químico da água e possibilita avaliar a disponibilidade de água livre suscetível a reações no substrato sólido. A redução de aw aumenta a duração da fase lag, diminui a taxa de crescimento do microrganismo e resulta em baixa quantidade de biomassa produzida (ORIOL et al., 1988). Em CES, em que se faz uso de substratos heterogêneos, as relações de água variam conforme o desenvolvimento da cultura, devido a alterações na estrutura do substrato, a liberação de produtos solúveis pelas reações enzimáticas, e a produção de água na respiração celular.

\subsection{2 $\mathrm{pH}$}

Outro fator importante em qualquer cultivo microbiano é o $\mathrm{pH}$, que pode variar em resposta as atividades metabólicas. A razão mais comum para essa variação é a secreção de ácidos orgânicos que promove redução do $\mathrm{pH}$. Por outro lado, a assimilação de ácidos orgânicos, que podem estar presentes em alguns meios, a hidrólise de uréia (fonte de nitrogênio), resultará alcalinização do meio (RAIMBAULT, 1998). Cada microrganismo apresenta faixa de $\mathrm{pH}$ para seu crescimento com um valor 
ótimo dentro de um intervalo. Fungos filamentosos têm bom crescimento em faixa de $\mathrm{pH}$ entre 2,0 e 9,0, com um faixa de pH ótimo de 3,8-6,0. Leveduras apresentam $\mathrm{pH}$ ótimo entre 4,0 e 5,0 e podem crescer numa faixa de $\mathrm{pH}$ de 2,5 a 8,5. Esta versatilidade de $\mathrm{pH}$ dos fungos pode ser empregada para prevenir ou minimizar a contaminação por bactérias, quando da escolha de pH ácido (KRISHNA, 2005).

No cultivo de fungos em meio sólido, ao contrário do que ocorre no sistema homogêneo do CS, o controle do $\mathrm{pH}$ in situ é impossível devido ao sistema heterogêneo e a falta de equipamentos adequados para determinar o $\mathrm{pH}$ em materiais sólidos. Entretanto, é possível reduzir a variação do pH no CES pela formulação do meio considerando a capacidade tamponante dos substratos empregados ou pelo uso de um tampão com componentes que não tem influência deletéria na atividade biológica (LONSANE et al., 1992).

\subsubsection{Temperatura}

Provavelmente, a mais importante de todas as variáveis físicas que afetam o desempenho do CES é a temperatura, porque o crescimento e produção de enzimas ou metabólitos são geralmente sensíveis a esse fator. Como no caso do $\mathrm{pH}$, os fungos podem crescer em uma ampla faixa de temperaturas, desde 20 a $55{ }^{\circ} \mathrm{C}$, e a temperatura ótima para o crescimento pode ser diferente daquela para a formação do produto (YADAV, 1988).

Smits et al. (1998) estudaram a influência da temperatura na cinética de cultivos de Trichoderma reesei QM9414 em farelo de trigo e reportaram uma temperatura máxima para crescimento de $41^{\circ} \mathrm{C}$. Além de parâmetros cinéticos como a velocidade específica de crescimento, a temperatura influenciou as atividades de respiração e a fisiologia do $T$. reesei, já que foi observada variação na atividade da enzima carboximetil-celulase com a temperatura.

O calor metabólico liberado pelas células microbianas durante o crescimento faz com que a temperatura do meio de cultura aumente. No CES, a falta de água livre e a 
baixa condutividade das partículas sólidas de natureza orgânica podem resultar gradientes de temperatura no meio de cultura. Diferentes métodos têm sido utilizados para a remoção do calor do meio de cultura (LONSANE et al., 1985). Embora a agitação do meio possa melhorar significativamente a velocidade de transferência de calor, ela não é utilizada em todos os processos de CES, pois nem todos os fungos e substratos sólidos podem tolerar as forças de cisalhamento e colisão que resultam da agitação. Assim, o crescimento de microrganismos em CES pode prosseguir em condições não isotérmicas.

Em alguns reatores de cultivos em meio sólido, como reatores de leito fixo, por exemplo, a aeração forçada é utilizada para remoção do calor. Sangsurasak e Mitchell (1998) reportaram que a evaporação pode remover até $78 \%$ do calor do leito durante o período de pico de geração de calor, mesmo quando o leito é aerado com ar saturado em água. Isto ocorre devido ao aumento da pressão de vapor à temperatura crescente. Porém, essa evaporação resulta grande perda de umidade e secagem do substrato sólido.

\subsection{REATORES PARA CES E AMPLIAÇÃO DE ESCALA}

Como dito anteriormente, os processos de CES são geralmente trabalhosos e de difícil controle das condições de cultivo. A reprodutibilidade é baixa entre diferentes bateladas e, além disso, é difícil prevenir contaminações. A evolução do processo de cultivo em estado sólido depende de reatores com bom desempenho. Um reator para cultivo em estado sólido deve: (1) ter um bom sistema de controle da temperatura, vazão de ar e umidade; (2) ter um sistema eficaz para prevenir contaminações; (3) apresentar meio homogêneo quanto a atividade de água, temperatura e composição, para que os microrganismos possam crescer uniformemente; (4) ser capaz de remover metabólitos nocivos, como $\mathrm{CO}_{2}$, rapidamente (CEN e XIA, 1999).

Os reatores utilizados em CES podem ser divididos em quatro tipos com base na forma de aeração ou no sistema de agitação empregado: reator tipo bandeja, reator de 
leito fixo, reator de tambor horizontal e reator de leito fluidizado. Cada tipo de reator tem vantagens e desvantagens, o que leva à necessidade de desenvolvimento de novos reatores com melhor projeto (SINGHANIA et al., 2009).

Durand (2003) reportou informações relevantes sobre vários reatores para CES, tanto em escala laboratorial quanto em escala industrial, que surgiram na década de 90 e o potencial de ampliação de escala para cada categoria de reator.

Apesar dos métodos para ampliação de escala do CS serem bem desenvolvidos os mesmos não podem ser aplicados diretamente para reatores de CES. A questão chave é manter as condições de cultivo em valores próximos ao ótimo após o aumento da escala (MITCHELL et al., 2006).

Para CS o passo limitante é geralmente a transferência de oxigênio através da interface gás-líquido. Nos processos de CES, entretanto, o crescimento pode ser limitado pela transferência de calor e pela transferência de massa, seja massa de água, de oxigênio ou de nutrientes.

Devido à falta de critérios bem fundados para a ampliação de escala, as aplicações de CES ficam limitadas. Como resultado, muitos processos comerciais são feitos em escalas intermediárias e envolvem cultivos em bandeja que são trabalhosos (MITCHELL et al., 1999).

Hoje, avanços estão sendo feitos para o desenvolvimento de estratégias de ampliação de escala para reatores de CES. Os mais significativos referem-se ao desenvolvimento de abordagens quantitativas para a análise e predição de desempenho do reator. Mais especificamente, a modelagem matemática de fenômenos biológicos e das transferências de calor e massa que ocorrem no processo (FERNÁNDEZ-FERNÁNDEZ e PÉREZ-CORREA, 2007; HAMIDI-ESFAHANI et al., 2004; HARDIN et al., 2002; MITCHELL et al., 2000; SAHIR et al., 2007; SANGSURASAK e MITCHELL, 1998). 


\subsubsection{Reatores tipo coluna de leito fixo}

Por ser relativamente fácil controlar as condições do CES em reatores de pequena escala ou escala de bancada, reatores tipo coluna são comumente utilizados para estudos de cinética (MITCHELL et al., 2006).

O sistema, envolvendo pequenas colunas submergidas em banho de água a temperatura controlada (Figura 1), ficou conhecido como "colunas de Raimbault" após ser usado por Maurice Raimbault na década de 80.

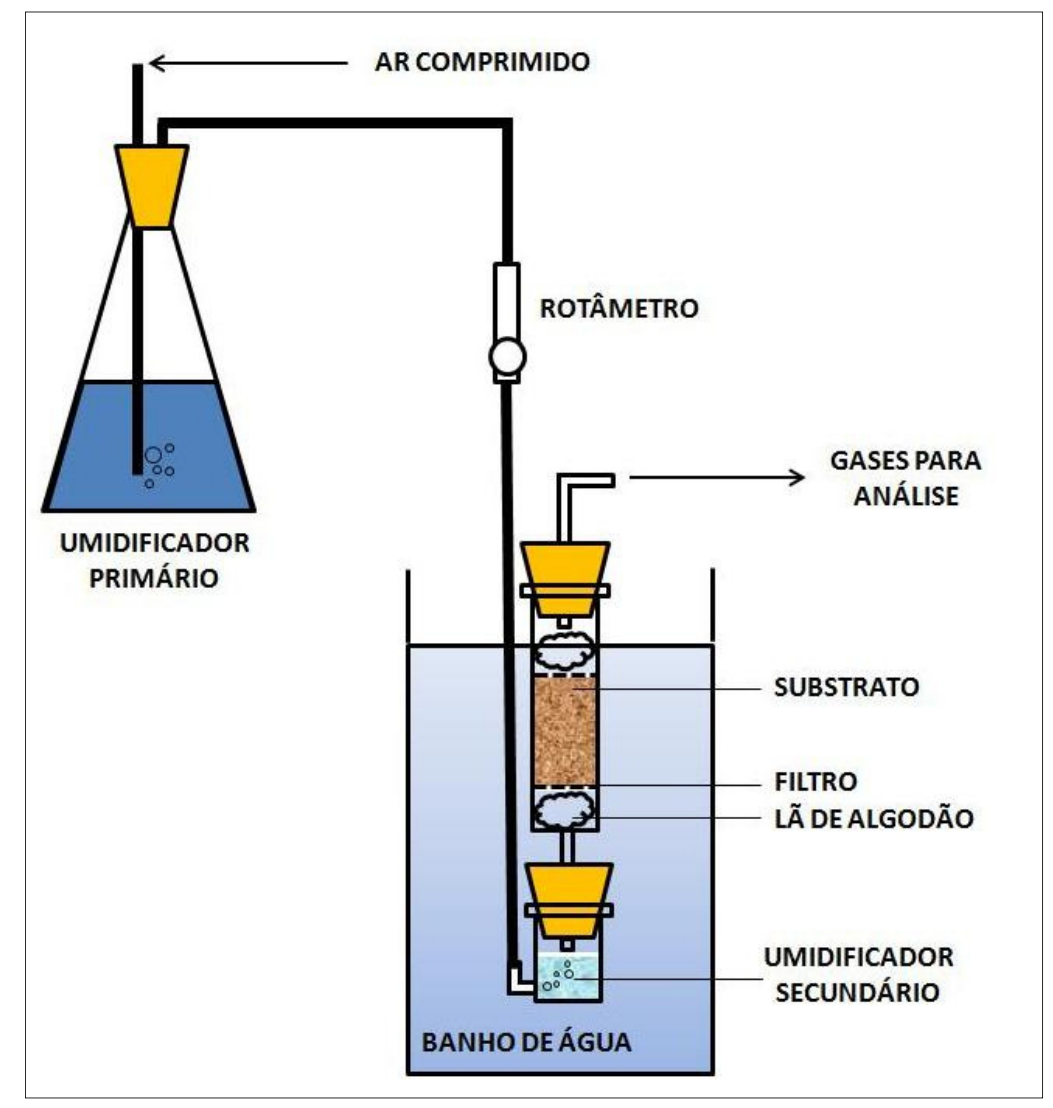

Figura 1 - Sistema básico de coluna de Raimbault.

O sistema admite a aeração forçada pelo leito do reator, permitindo uma maior disponibilidade de ar dentro do leito do que a obtida em cultivos realizados em frascos Erlenmeyer, em que não há aeração forçada. 
O diâmetro das colunas deve ser entre 1 e $2 \mathrm{~cm}$, o que minimiza gradientes radiais de temperatura. Saucedo-Casteneda et al. (1990) encontraram significativos gradientes radiais de temperatura em colunas com $6 \mathrm{~cm}$ de diâmetro. A altura da coluna pode variar de 10 a $20 \mathrm{~cm}$ ou mais (MITCHELL et al., 2006).

É importante saturar o ar de entrada das colunas para minimizar a perda de umidade do leito, uma vez que não é prático adicionar água às colunas durante os cultivos. O resfriamento do leito é menos eficiente à medida que o ar passa pela coluna, pois, ao passar pela coluna, o ar retira calor do substrato e sua temperatura aumenta (SAUCEDO-CASTENEDA et al., 1990).

\subsection{ESTIMATIVA DE BIOMASSA EM CES}

A concentração de massa celular é variável fundamental na caracterização do crescimento microbiano e estabelecimento da sua cinética. Porém, no CES, o microrganismo está intimamente ligado à matriz sólida, dificultando sua quantificação, pois, a biomassa não pode ser totalmente separada do meio sólido (DURAND e CHEREAU, 1988; DESGRANGES et al., 1991).

Há alguns métodos indiretos para estimativa da concentração de massa celular em CES, que podem ser divididos em três categorias: (1) medida de componentes celulares como glicosamina, ergosterol, proteínas, DNA; (2) medida de atividade biológica, como ATP, atividades enzimáticas, velocidade de respiração e (3) medida de consumo de nutrientes (DESGRANGES et al., 1991; SINGHANIA et al., 2009).

A medida de componentes celulares apresenta dificuldades quanto à reprodutibilidade, pois, a concentração desses componentes pode variar com a espécie do fungo, as condições de cultivo e a idade da cultura (OOIJKASS et al., 1998).

A velocidade de respiração pode ser utilizada na estimativa da concentração celular e sua determinação está baseada na velocidade de consumo de oxigênio (OUR) ou de produção de dióxido de carbono (CER) (RAIMBAULT, 1998; SINGHANIA et al., 2009). 
A maior dificuldade em relação a estimativa da concentração de biomassa baseada no balanço gasoso é a obtenção dos valores do fator de conversão de oxigênio a células $\left(\mathrm{Y}_{\mathrm{x} / \mathrm{O}}\right)$ e do coeficiente de respiração para manutenção das células $\left(\mathrm{m}_{\mathrm{o}}\right)$. Este último pode ser definido como a velocidade específica de respiração para $\mu=0$, ou seja, a velocidade específica de consumo de $\mathrm{O}_{2}$ para manter as células viáveis (PIRT, 1975).

Rodriguez-Leon et al. (1998) estimaram o crescimento celular de Aspergillus niger QH-2 em meio sólido a partir de OUR. Os autores concluíram que as possíveis variações de $m_{0}$ e $Y_{x / O}$ ao longo do cultivo não podem ser desprezadas. Koutinas et al. (2003) estimaram o crescimento celular a partir da produção de $\mathrm{CO}_{2}$, porém concluem que o fator de conversão de $\mathrm{CO}_{2}$ a células $\left(\mathrm{Y}_{\mathrm{X} / \mathrm{CO} 2}\right)$ também varia com as condições de cultivo, causando erros. Em sua tese de doutorado, Maiorano (1990) estudou o crescimento de Aspergillus oryza em meio sólido. Porém, utilizou valores de $\mathrm{Y}_{\mathrm{X} / \mathrm{O}}$ e $\mathrm{m}_{\mathrm{o}}$ obtidos através de cultivos em meio líquido para o cálculo da estimativa celular.

\subsection{A RECUPERAÇÃO DE PRODUTOS EM CES}

As etapas de concentração, recuperação e purificação constituem parte importante de um processo biotecnológico pois delas depende a pureza do produto.

$\mathrm{Na}$ produção comercial de enzimas microbianas, por exemplo, os custos de recuperação podem chegar a $80 \%$ do total dos custos de produção (WENZIG et al., 1993).

No CES, o produto é formado na superfície do substrato sólido de modo que é necessário selecionar solventes para extração do produto da massa sólida. A recuperação de enzimas produzidas por CES, se feita de forma adequada, pode resultar um extrato bruto concentrado, reduzindo assim, o número de etapas de purificação. No entanto, após o processo de extração, alguns solventes geralmente permanecem nos sólidos, causando uma perda de enzimas de quase 90\% (CASTILHO et al., 1999). Kumar e Lonsane (1987) e Ramadas et al. (1995) mostraram ser 
necessário desenvolver técnicas de extração eficientes para tornar o cultivo em estado sólido aplicável para a produção de enzimas de alta pureza e permitir sua efetiva exploração comercial.

Os fatores que mais influenciam a extração da enzima são o tipo de solvente, a relação sólido-líquido, a temperatura, a agitação, o tempo de contato e as relações entre todos esses fatores (CASTILHO et al., 1999; CASTILHO et al., 2000; HECK et al., 2005; IKASARI e MITCHELL,1996). A estabilidade térmica da enzima também deve ser considerada porque depende do tempo de exposição (CASTILHO et al., 2000). Além disso, enzimas de naturezas distintas podem responder de maneira diferente a determinado processo de extração (REZAEl et al., 2011).

Água destilada ou água deionizada são solventes comumente utilizados para extração de enzimas (AHMED, 2008; REZAEl et al. 2011). Yang e Chiu (1987) utilizaram solução de cloreto de sódio na extração de proteases do meio sólido. Castilho et al. (2000) extraíram pectinases de farelo de trigo com tampão acetato (pH $4,4)$.

Díaz et al. (2007) reportaram que aumentar a quantidade de solvente leva a um aumento da quantidade de enzima extraída, recomendando assim, extrações repetitivas para melhor utilização do sólido fermentado. Vários estudos sugerem que Tween 80 e outros tensoativos contribuem para extração de celulases em substratos lignocelulósicos (ERIKSSON et al., 2002; ZHENG et al., 2008).

Ghildyal et al. (1991) estudaram a extração de amiloglicosidase de farelo fermentado em frascos em condições estáticas e sob agitação (220 rpm) com tempos de exposição variando de $30 \mathrm{~min}$ a $5 \mathrm{~h}$. A maior atividade de amiloglicosidase foi obtida após 3h de extração em frasco agitado. Ramakrishna et al. (1982) e Ahmed (2008) também obtiveram melhores resultados para extração de enzima sob agitação que para extração estática. 


\subsection{PRODUÇÃO DE CELULASES POR CES}

Celulases são enzimas capazes de hidrolisar a celulose. Atualmente, essas enzimas são empregadas principalmente na produção de detergente, na indústria têxtil e de papel e celulose (KIRK et al., 2002). Porém, as celulases tem ganhado destaque entre pesquisadores pelo seu potencial na hidrólise de materiais lignocelulósicos para a produção etanol (HIMMEL et al., 1999).

Celulases são um complexo enzimático formado por três grupos principais de enzimas que agem sinergicamente sobre a celulose, são eles: a endoglicanase (1,4-bD-glucana-4-gucano-hidrolase, EC-3.2.1.4), a celobio-hidrolase (1,4-b-D-glucanacelobio-hidrolase, EC-3.2.1.91) e a $\beta$-glicosidase (b-D-glicosídeo gluco-hidrolase, EC3.2.1.21) (ESTERBAUER et al., 1991).

Endoglicanase é a enzima responsável por iniciar a hidrólise, atuando randomicamente nas regiões internas da estrutura amorfa da fibra celulósica, o que resulta na liberação de oligossacarídeos de diversos graus de polimerização e, consequentemente, gerando novos terminais, sendo um redutor (quando a glicose possui uma hidroxila heterosídica livre) e um não redutor (quando a hidroxila heterosídica da molécula da extremidade participa de ligação com a glicose adjacente). Da ação da endoglicanase resulta uma rápida solubilização do polímero celulósico (redução do grau de polimerização), devido à sua fragmentação em oligossacarídeos (CASTRO, 2010).

As celobio-hidrolases agem sobre os terminais redutores e não redutores formados pelas endoglicanases liberando unidades de celo-oligossacarídeos e celobiose que são então hidrolisados pela $\beta$-glicosidase para liberação de glicose, completando assim a hidrólise da celulose (SUKUMARAN et al., 2005).

Industrialmente, cultivos submersos são utilizados para produção de celulases. Porém, a baixa eficiência e o custo relativamente alto dessas enzimas têm dificultado sua aplicação na conversão de biomassa (SINGHANIA et al., 2010).

Assim, cada vez mais estudos sobre produção de celulases têm sido realizados, incluindo a produção por CES, visando diminuir o custo da enzima pelo aumento da 
produtividade e o uso de resíduos sólidos como substrato (CAMASSOLA e DILLON, 2010; VINIEGRA-GONZÁLEZ et al., 2003).

Nos últimos anos, intensificaram-se as investigações para identificação e isolamento de microrganismos capazes de produzir celulases. A maioria dos estudos tem sido sobre o sistema de celulase de fungos filamentosos como Trichoderma, Penicillium, Aspergillus e Fusarium (GONG et al., 1979; MANDELS e REESE, 1964; OGAWA e TOYAMA, 1972; WOOD, 1969; WOOD e MCCRAE, 1986). Dentre esses fungos o mais estudado é o Trichoderma reesei por apresentar elevada produção específica de celulases, principalmente quanto às frações de endoglicanase e celobiohidrolase (CHAHAL, 1985; HAYWARD et al., 1999; SINGHANIA et al., 2010; SMITS et al., 1996; WEN et al., 2005). Já os fungos do gênero Aspergillus são conhecidos por produzirem coquetéis enzimáticos com altas concentrações da enzima $\beta$-glicosidase (GRAJEK, 1987).

Outros microrganismos como fungos termofílicos aeróbios, fungos mesofílicos anaeróbios, bactérias termofílicas e mesofílicas, aeróbias e anaeróbias, também produzem celulases ativas (BHAT e BHAT, 1997). Os microrganismos celulolíticos termofílicos são de particular interesse devido à sua capacidade de produzir enzimas termoestáveis, isto é, que apresentam maior estabilidade à temperatura. As enzimas termoestáveis são geralmente mais resistentes a desnaturação e a proteólise, além de serem estáveis em amplas faixas de pH (GOMES et al., 2009; KUMAR e NUSSINOV, 2001). Alguns notáveis microrganismos termofílicos são Clostridium thermocellum, Thermoascus aurantiacus e Sporotrichum thermophile (BHAT e MAHESHWARI, 1987; BHAT et al., 1993; KHANDKE et al., 1989; LAMED e BAYER, 1988; SUGDEN e BHAT, 1994). Estes microrganismos são capazes de crescer em uma ampla gama de substratos, com risco mínimo de contaminação por outros patógenos (LAMED e BAYER, 1988). Por causa dessas vantagens, os microrganismos celulolíticos termofílicos têm atraído o interesse de investigação nos últimos anos.

Celulases são um sistema de enzimas cuja síntese se dá sob indução sendo a celulose um dos melhores indutores. Outros indutores são soforose, lactose e celobiose (STERNBERG e MANDELS, 1979). Assim, na produção de celulases por CES, a celulose dos substratos sólidos tem papel essencial na indução (CEN e XIA, 1999). 
Ao longo dos anos, melhorias no processo de produção e aplicação de celulases vêm sendo geradas no que tange ao isolamento de microrganismos produtores de celulases, à clonagem e expressão de genes para aumento da expressão microbiana de celulases, à purificação e caracterização de componentes deste complexo enzimático, ao entendimento sobre os mecanismos de ataque à celulose, à determinação das estruturas tridimensionais das celulases e à demonstração do potencial industrial dessas enzimas (CASTRO, 2010).

A Tabela 2 lista alguns trabalhos reportados na literatura para produção de celulases por diferentes microrganismos e substratos, quanto a atividade em "Filter Paper". A atividade em "Filter Paper" é uma das metodologias mais utilizadas para medida de atividade global de celulases. Desenvolvida por Ghose (1987), essa metodologia baseia-se na promoção da reação de hidrólise de papel de filtro Whatman no. 1 por $1 \mathrm{~h}$ a $50^{\circ} \mathrm{C}$, sob ação do complexo enzimático. Findo o período de reação, determina-se a concentração de açúcares redutores com 0 uso de ácido dinitrossalicílico (DNS). A unidade FPU equivale a $\mu \mathrm{mol}$ de glicose produzido por minuto.

Tabela 2 - Produção de celulases por fungos cultivados em substratos lignocelulósicos (adaptado de CAMASSOLA e DILLON, 2007).

\begin{tabular}{lccl}
\hline \multicolumn{1}{c}{ Microrganismo } & Substrato & $\begin{array}{c}\text { Atividade Enzimática } \\
\text { (FPU.gms }{ }^{-1} \text { ) }\end{array}$ & Referência \\
\hline $\begin{array}{l}\text { Penicillium echinulatum } \\
\text { 9A02S1 }\end{array}$ & $\begin{array}{c}\text { Bagaço pré-tratado e farelo } \\
\text { de trigo }\end{array}$ & 32,9 & Camassola et al. (2007) \\
Trichoderma harzianum & Bagaço de cana & 24,2 & Mekala et al. (2008) \\
$\begin{array}{l}\text { Penicillium decumbens } \\
\text { T. reesei LM-UC 4E1 }\end{array}$ & Farelo e palha de trigo & 18,0 & Deschamps et al . (1985) \\
T. reesei LM-UC 4 & Bagaço de cana & 17,7 & Mo et al . (2004) \\
Myceliophthora sp. & Bagaço de cana & 10,0 & $\begin{array}{l}\text { Gutierrez-Correa e Tengerdy } \\
\text { (1997) }\end{array}$ \\
Myceliophthora sp. & Palha de arroz & 5,3 & $\begin{array}{l}\text { Gutierrez-Correa e Tengerdy } \\
\text { (1997) }\end{array}$ \\
Myceliophthora sp. & Palha de trigo & 2,4 & Badhan et al . (2007) \\
Myceliophthora sp. & Farelo de trigo & 1,4 & Badhan et al . (2007) \\
Myceliophthora sp. & Bagaço de cana & 0,7 & Badhan et al . (2007) \\
\hline
\end{tabular}




\subsection{MATERIAL LIGNOCELULÓSICO}

O material lignocelulósico é a biomassa mais abundante do planeta, tem baixo custo e potencial uso na produção em larga escala de combustíveis e produtos químicos, oferecendo vantagens econômicas, ambientais e estratégicas (WYMAN, 1994). Esse material compreende os resíduos agrícolas (bagaço de cana-de-açúcar, sabugo de milho, palhas de trigo, de cana, de arroz, entre outros), resíduos florestais e madeiras. São constituídos basicamente de celulose (32-50\%), hemicelulose (19-25\%) e lignina (23-32\%), além de uma pequena parte de ácidos orgânicos, sais e minerais (PANDEY et al., 2000).

A celulose, polímero mais abundante na Terra, é composta por centenas de moléculas de glicose ligadas por pontes $\beta(1,4)$-glicosídicas. A unidade básica que se repete é o dissacarídeo celobiose (Figura 2). As cadeias de celulose possuem organização fibrilar, com ligações de hidrogênio intermoleculares e intramoleculares, apresentando regiões cristalinas e amorfas que ocorrem em intervalos irregulares, como mostrado na Figura 3. Nas regiões amorfas as ligações de hidrogênio ocorrem em menor grau e estas regiões estão relacionadas à hidrólise da celulose por rota ácida ou enzimática (LEHNINGER, 1985). Organizadas na forma de microfibrilas, as regiões cristalinas são menos acessíveis a agentes químicos e enzimáticos, o que dificulta a hidrólise. Estima-se que a porção cristalina seja de 50 a $90 \%$ da celulose (FAN et al., 1980).

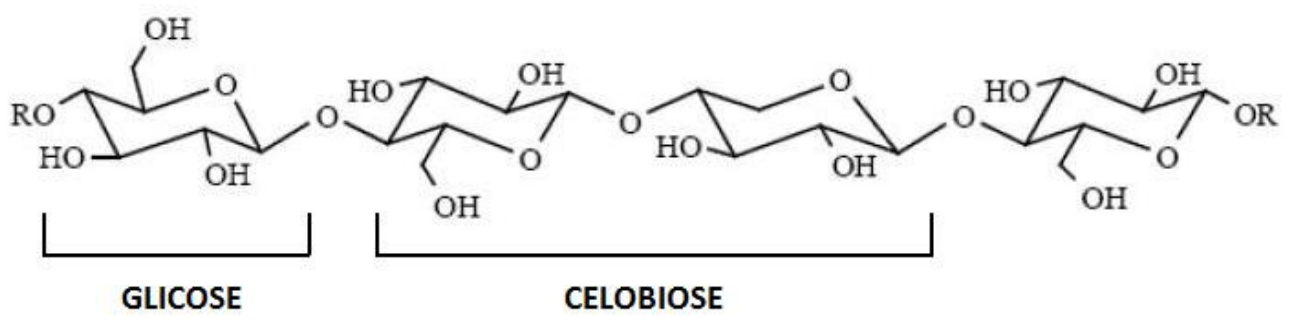

Figura 2 - Estrutura de um fragmento da celulose (FENGEL e WEGENER, 1989) 


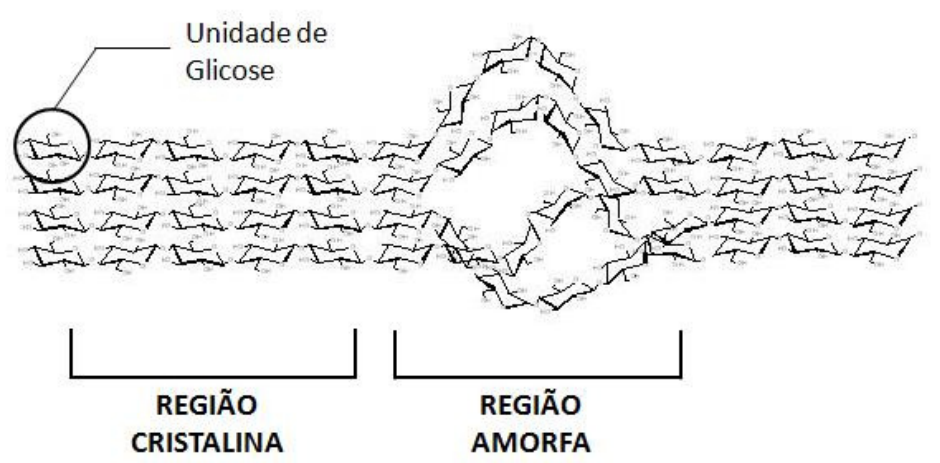

Figura 3 - Estrutura de uma fibrila elementar da celulose (CHAGAS, 2007)

A hemicelulose é um heteropolímero altamente ramificado contendo açúcares como hexoses (glicose, galactose, manose, ramanose), pentoses (xilose, arabinose), e ácidos urônicos. A hemicelulose encontra-se intercalada às microfibrilas de celulose, proporcionando elasticidade e impedindo que as microfibrilas se toquem. É mais solúvel que a celulose e por isso mais facilmente hidrolisada. Sua composição varia de acordo com a espécie da planta.

Lignina é um complexo polímero fenólico, heterogêneo e amorfo, com elevado peso molecular e altamente insolúvel. Na natureza, a lignina é fortemente ligada à celulose e à hemicelulose, proporcionando resistência mecânica, suporte e agindo como uma barreira física para ataque de microrganismos e água.

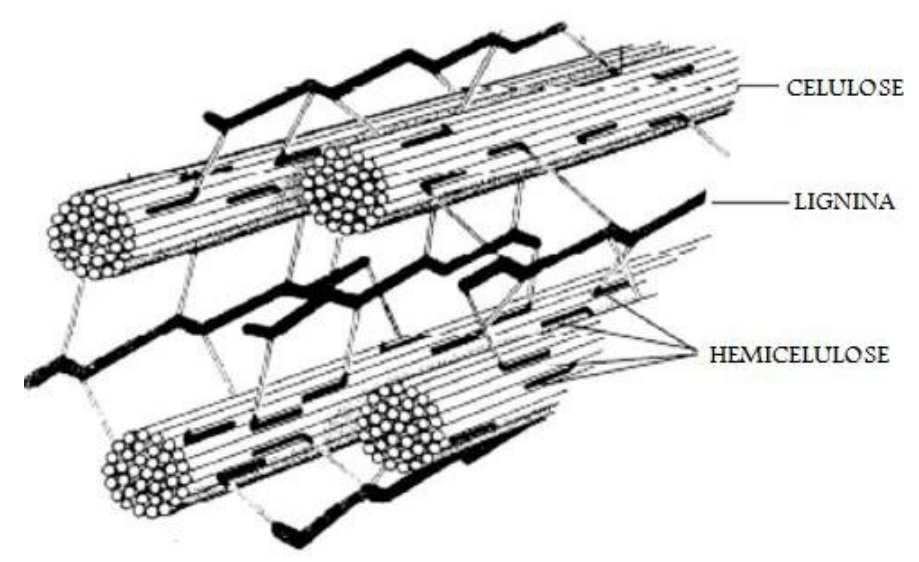

Figura 4 - Complexo lignocelulósico da parede celular vegetal

Os maiores obstáculos para a hidrólise da celulose de materiais lignocelulósicos são a recalcitrância da própria celulose cristalina, proveniente da estrutura linear das 
cadeias de celulose compactadas por microfibrilas, e a alta proteção que a lignina proporciona a estrutura celulósica, atuando como uma barreira física ao ataque enzimático.

\subsubsection{Bagaço de cana-de-açúcar}

O bagaço de cana-de-açúcar é o material lignocelulósico obtido após a moagem da cana-de-açúcar nas usinas de açúcar e álcool. É formado por um conjunto de fragmentos bastante heterogêneo, com dimensões que oscilam de 1 a $25 \mathrm{~mm}$. A granulometria do bagaço depende do trabalho de moagem e da variedade da cana. Do ponto de vista físico, o bagaço industrial é constituído por cerca de $50 \%$ de umidade, $45 \%$ de estruturas fibrilares e $5 \%$ de extrativos e componentes inorgânicos. Devido ao seu alto teor de carboidratos (aproximadamente 50\% de celulose e $25 \%$ de hemicelulose), teor de lignina relativamente baixo e sua disponibilidade como um resíduo industrial, o bagaço é particularmente adequado como fonte de carbono para bioconversão (MARTIN et al., 2002).

No Brasil, como resíduo da usina de cana-de-açúcar, o bagaço é em parte queimado em caldeiras de baixa eficiência para produção de energia elétrica e térmica para os processos industriais da própria usina e também para resolver os problemas com descarte, restando ainda um excedente de cerca de $10 \%$ de todo o bagaço gerado. Porém, com a perspectiva da expansão do cultivo de cana-de-açúcar, o aumento da eficiência de co-geração de energia nas usinas, a redução do consumo interno de energia e a recuperação da palha para uso energético, há uma tendência ao aumento dos excedentes de bagaço de cana-de-açúcar, que então estariam disponíveis para outros usos como, por exemplo, a produção de etanol de $2^{\underline{a}}$ geração (MACEDO, 2005). 


\subsection{PRÉ-TRATAMENTO DO MATERIAL LIGNOCELULÓSICO}

No contexto do processo de conversão biológica da biomassa celulósica em açúcares para a produção de etanol e outros produtos, o pré-tratamento é necessário para alterar a estrutura da biomassa lignocelulósica e tornar a celulose mais acessível ao ataque das enzimas, que convertem os polímeros de carboidratos em açúcares fermentescíveis. O objetivo é romper o escudo naturalmente formado pela lignina, reduzir a cristalinidade da celulose e aumentar a porosidade do material, conforme representado na Figura 5 (MOSIER et al., 2005).

Outros requisitos para um pré-tratamento efetivo são: aumentar a área superficial do material, evitar a degradação ou a perda de carboidratos maximizando os rendimentos em açúcares; evitar ou minimizar a formação de subprodutos inibitórios para a hidrólise e processos de fermentação subseqüentes (HSU, 1996; KUMAR et al., 2009). O pré-tratamento pode ser o processo mais caro na conversão de biomassa em combustíveis, mas tem grande potencial para melhorias na eficiência e redução de custos através de investigação e desenvolvimento de tecnologias (KUMAR et al. 2009).

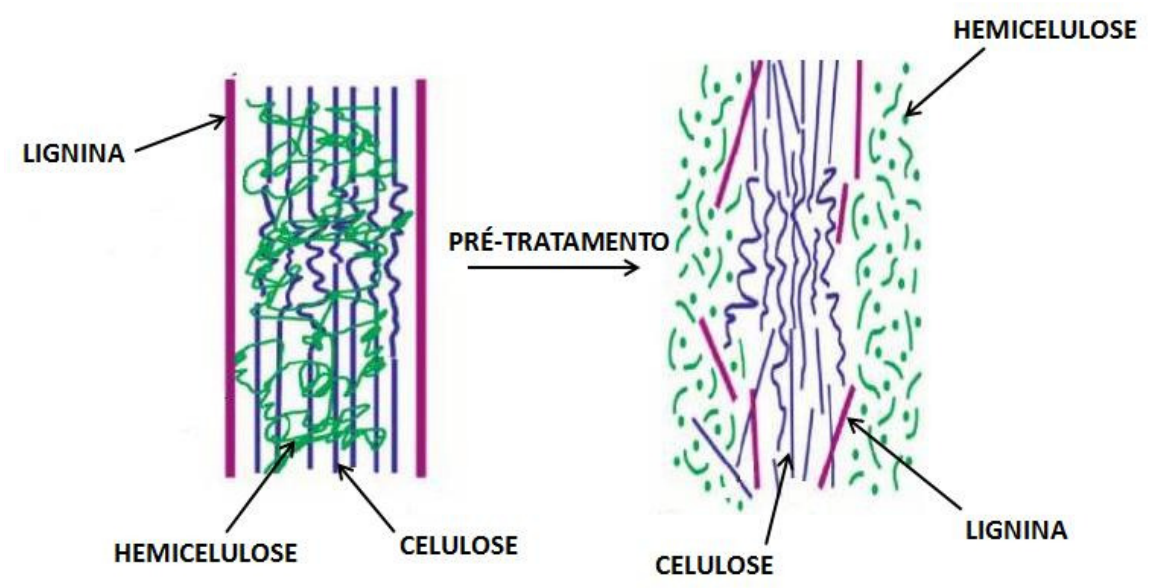

Figura 5 - Esquema do pré-tratamento do material lignocelulósico

Vários métodos já foram introduzidos para pré-tratamento de materiais lignocelulósicos, estes métodos são classificados em três grupos principais: físicos, químicos e biológicos, além de uma possível combinação entre eles. Os principais processos de pré-tratamento estão sumarizados na Tabela 3. 
Tabela 3 - Processos de pré-tratamento de biomassa lignocelulósica (TAHERZADEH e KARIMI, 2008).

\begin{tabular}{|c|c|c|}
\hline Processos & $\begin{array}{c}\text { Possíveis mudanças na } \\
\text { biomassa }\end{array}$ & Observações \\
\hline \multicolumn{3}{|l|}{ Físicos } \\
\hline Moagem & \multirow{3}{*}{$\begin{array}{l}\text { - Aumento da área superficial } \\
\text { - Diminuição da cristalinidade da } \\
\text { celulose }\end{array}$} & - Alto consumo de energia \\
\hline Irradiação & & \multirow{2}{*}{$\begin{array}{l}\text { - A maioria dos métodos não } \\
\text { remove a lignina }\end{array}$} \\
\hline - Raio Gama & & \\
\hline - Feixe de elétrons & \multirow{6}{*}{$\begin{array}{l}\text { - Redução do grau de polimerização } \\
\text { da celulose }\end{array}$} & \multirow{2}{*}{$\begin{array}{l}\text { - Dificuldade quanto a aplicação } \\
\text { industrial }\end{array}$} \\
\hline - Microondas & & \\
\hline Extrusão & & \multirow[t]{4}{*}{ - Não utilizam produtos químicos } \\
\hline Pirólise & & \\
\hline Hidrotérmico & & \\
\hline Expansão & & \\
\hline \multicolumn{3}{|l|}{ Químicos e Físico-químicos } \\
\hline Explosão à vapor & \multirow{3}{*}{$\begin{array}{l}\text { - Aumento da área superficial } \\
\text { - Deslignificação parcial ou quase } \\
\text { completa }\end{array}$} & \multirow{3}{*}{$\begin{array}{l}\text { - Estão entre os métodos mais } \\
\text { eficazes e promissores para } \\
\text { aplicações industriais }\end{array}$} \\
\hline Alcalinos & & \\
\hline - Hidróxido de sódio & & \\
\hline - Sulfito de amônia & \multirow{2}{*}{$\begin{array}{l}\text { - Diminuição da cristalinidade da } \\
\text { celulose }\end{array}$} & \multirow{2}{*}{$\begin{array}{l}\text { - Geralmente são métodos } \\
\text { rápidos }\end{array}$} \\
\hline - Amônia & & \\
\hline Ácidos & \multirow{7}{*}{$\begin{array}{l}\text { - Redução do grau de polimerização } \\
\text { da celulose } \\
\text { - Hidrólise parcial ou completa de } \\
\text { hemiceluloses }\end{array}$} & \multirow{7}{*}{$\begin{array}{l}\text { - Normamelmente são feitas em } \\
\text { condições severas } \\
\text { (temperatura, pressão, pH) } \\
\text { - Utilizam produtos químicos }\end{array}$} \\
\hline - Ácido sulfúrico & & \\
\hline - Ácido fosfórico & & \\
\hline - Ácido hidroclorídrico & & \\
\hline Agentes oxidantes & & \\
\hline - Peróxido de hidrogênio & & \\
\hline - Ozônio & & \\
\hline \multicolumn{3}{|l|}{ Biológicos } \\
\hline Fungos & - Deslignificação & - Baixo consumo de energia \\
\hline \multirow[t]{4}{*}{ Actinomicetos } & $\begin{array}{l}\text { - Redução do grau de polimerização } \\
\text { da celulose }\end{array}$ & $\begin{array}{l}\text { - Condições ambientais } \\
\text { brandas }\end{array}$ \\
\hline & \multirow[t]{3}{*}{ - Hidrólise parcial de hemiceluloses } & - Não utilizam produtos químicos \\
\hline & & - Métodos lentos \\
\hline & & $\begin{array}{l}\text { - Não são considerados para } \\
\text { aplicação industrial }\end{array}$ \\
\hline
\end{tabular}




\subsubsection{Pré-tratamento por radiação ionizante}

A radiação ionizante pode ser um método eficaz de pré-tratamento de biomassa lignocelulósica pois é capaz de modificar e romper a estrutura de lignocelulose. A ação da radiação em macromoléculas de materiais lignocelulósicos se dá pela interação dos radicais livres produzidos tanto pela interação com a água presente na biomassa, como pela ação direta nas ligações de átomos de carbono e oxigênio. A eficiência das reações induzidas pela radiação sobre o material celulósico depende da estrutura do polímero e da dose de radiação absorvida (CHARLESBY, 1981, KHAN et al., 2006).

Para reduzir a dose necessária de radiação, acelerar a degradação dos materiais lignocelulósicos e assim, diminuir os custos do processo, geralmente outros tratamentos são realizados juntamente com a radiação, como por exemplo, tratamento com $\mathrm{NaOH}$ e tratamento por aquecimento (CHOSDU et al., 1993; LU e KUMAKURA, 1993). Chumping et al. (2008) observaram um efeito sinérgico entre radiação e esmagamento mecânico no tratamento de palha de trigo.

Apesar do tratamento por radiação ser capaz de melhorar a hidrólise enzimática de materiais lignocelulósicos, este método é ainda muito caro para ser utilizado em aplicações industriais (TAHERZADEH e KARIMI, 2008).

\subsubsection{Pré-tratamento por explosão à vapor}

Entre os processos físico-químicos, a explosão à vapor é um dos prétratamentos mais comumente utilizado em materiais lignocelulósicos (SUN e CHENG, 2002). Neste método, a biomassa é tratada com vapor saturado à alta pressão e, em seguida, a pressão é rapidamente reduzida, o que faz com que o material sofra uma descompressão explosiva. O processo causa a degradação da hemicelulose e a transformação da lignina devido as altas temperaturas, aumentando assim o potencial de hidrólise da celulose (KUMAR et al., 2009). A adição de $\mathrm{H}_{2} \mathrm{SO}_{4}$ (ou $\mathrm{SO}_{2}$ ) ou $\mathrm{CO}_{2}$ 
(tipicamente $0,3-3 \%$ em massa) ao processo de explosão à vapor pode diminuir o tempo e a temperatura do processo, melhorar efetivamente a hidrólise, diminuir a produção de compostos inibitórios e remover completamente a hemicelulose (BALLESTEROS et al., 2006; STENBERG et al., 1998).

Uma das limitações do pré-tratamento por explosão à vapor é a geração de produtos que podem ser inibitórios para o crescimento microbiano e a hidrólise enzimática, tais como furfural e hidroximetilfurfural. Devido a formação desses produtos, a biomassa pré-tratada precisa ser lavada com água para remover os materiais inibitórios juntamente com a hemicelulose solúvel em água. A lavagem com água diminui o rendimento da sacarificação global através da remoção de açúcares solúveis, tais como aqueles gerados pela hidrólise da hemicelulose (KUMAR et al., 2009).

\subsection{HIDRÓLISE ENZIMÁTICA DA BIOMASSA LIGNOCELULÓSICA}

A hidrólise da biomassa lignocelulósica, também chamada de sacarificação, consiste na liberação de açúcares pela quebra da celulose e hemicelulose (DUFF e MURRAY, 1996).

A hidrólise da biomassa lignocelulósica pode ser conduzida de duas formas: por tratamento químico, utilizando-se ácido diluído ou concentrado; ou por tratamento enzimático, utilizando-se, sobretudo, celulases e xilanases. A hidrólise enzimática da celulose ocorre em condições mais brandas de pressão, temperatura e pH em comparação à hidrólise química, e exibe elevada especificidade, eliminando a ocorrência de substâncias tóxicas (furfurais e derivados de lignina) às células microbianas que serão utilizadas na posterior fermentação dos açúcares (CASTRO, 2010).

As variáveis mais importantes a serem consideradas na hidrólise enzimática de materiais lignocelulósicos são a concentração de sólidos do substrato, a dosagem de enzima e as condições de temperatura e pH (SUN e CHENG, 2002). 


\subsubsection{Concentração de sólidos}

A concentração de sólidos é um dos principais fatores que afetam o rendimento da hidrólise enzimática de celulose. Há uma relação direta entre a concentração de sólidos e a concentração final de açúcares na sacarificação, a qual, por sua vez, determina a concentração de etanol na etapa subseqüente de fermentação alcoólica. $O$ teor alcoólico ao final da fermentação tem efeito significativo no custo de produção do etanol devido ao tamanho das colunas de destilação e a energia requerida na destilação (KATZEN et al., 1999; WINGREN et al., 2003). Vários autores afirmam que a concentração de etanol necessária para tornar a destilação economicamente viável é de $4 \%$ em massa. Para a maior parte dos materiais lignocelulósicos isso significa $15 \%$ em massa de sólidos na hidrólise considerando uma porcentagem de celulose de $60 \%$ no substrato e conversão de celulose a glicose de 90\% (FAN et al., 2003; JORGENSEN et al., 2006; WINGREN et al., 2003)

Contudo, há problemas técnicos para se realizar a hidrólise com concentração de sólidos acima de 10-15\% (em massa). A viscosidade inicial do material nessas concentrações é alta, dificultando a agitação e aumentando o consumo de energia em tanques agitados (FAN et al., 2003; MOHAGHEGHI et al., 1992). Há também a dificuldade de difusão das enzimas quando da elevada concentração de sólidos no meio. Tengborg et al. (2001) verificaram uma diminuição de $16 \%$ na conversão de celulose a glicose ao aumentar o teor de sólidos de $2 \%$ para $5 \%$.

\subsubsection{Dosagem de celulases}

A literatura reporta dados de carga de celulase na hidrólise enzimática desde 7 até $33 \mathrm{FPU} / \mathrm{g}$ de celulose, dependendo do tipo de substrato e o pré tratamento que o mesmo sofreu, da velocidade desejada para a reação e da concentração inicial de sólidos. O aumento da dosagem de celulase no processo de hidrólise pode aumentar o 
rendimento da hidrólise. Porém, existe uma concentração a partir da qual não é compensatório aumentar a atividade enzimática, pois os sítios do substrato estarão saturados pelos biocatalisadores. Além disso, quanto maior a carga enzimática adicionada, maior o custo do processo (CASTRO, 2010; SUN e CHENG, 2002).

A dosagem de $10 \mathrm{FPU} / \mathrm{g}$ de celulose é geralmente usada em estudos em escala de bancada, pois rende níveis elevados de glicose em um tempo razoável (48-72h) (GREGG e SADDLER, 1996). Quanto à dosagem de $\beta$-glicosidase na reação de hidrólise, muitos autores reportam proporção de $\beta$-glicosidase/FPA variando de 0,5 a 1,5. Uma das principais razões dessa variação é que a atividade de Filter Paper é fortemente dependente da quantidade de $\beta$-glicosidase, dificultando a definição da razão ótima entre atividade de $\beta$-glicosidase e atividade de Filter Paper para hidrólise de celulose (DUFF et al., 1987).

\subsubsection{Inibição pelos produtos finais da reação de hidrólise}

As enzimas endoglicanase e $\beta$-glicosidase geralmente sofrem inibição por seus produtos finais de hidrólise, respectivamente, celobiose e glicose. Muitos métodos têm sido desenvolvidos para reduzir essa inibição, entre eles tem-se o uso de altas concentrações de enzimas, a suplementação de $\beta$-glicosidase durante a hidrólise e a remoção de açúcares durante a hidrólise por ultrafiltração (SUN e CHENG, 2002).

A inibição das enzimas pelos produtos das reações de hidrólise é a razão por que muitos pesquisadores estudam a sacarificação e fermentação simultânea (SSF), que consiste em realizar as etapas de hidrólise e fermentação simultaneamente no mesmo vaso para produção de etanol. A idéia foi patenteada por Gauss em 1976 (OLOFSSON et al., 2008). De acordo com Phillippidis et al. (1992), a presença de etanol na reação de hidrólise tem um efeito inibitório menor do que o efeito causado pela presença de glicose. Bezerra e Dias (2005) constataram que a conversão de celobiose a etanol nos ensaios de SSF, tem resultado positivo sobre a hidrólise da celulose devido ao maior poder de inibição da celobiose em comparação ao do etanol. 


\section{MATERIAIS E MÉTODOS}

\subsection{CULTIVOS EM ESTADO SÓLIDO}

\subsubsection{Microrganismo e Inóculo}

O microrganismo empregado foi o Myceliophthora sp. M77, um fungo recentemente isolado através de um programa ambiental para preservação da biodiversidade no estado de São Paulo (BIOTA FAPESP). Esse microrganismo foi cedido pela equipe da IBILCE/ UNESP/ Campus de São José do Rio Preto/Depto. de Biologia. O microrganismo foi preservado através de cultivos subseqüentes em farelo de trigo e bagaço de cana-de-açúcar.

No preparo do estoque, esporos da cepa foram suspensos em solução de $\mathrm{NaCl}$ 0,9\% (massa) e inoculados em $20 \mathrm{~g}$ de meio composto por farelo de trigo e bagaço de cana-de-açúcar na proporção 20:80 (massa), com 60\% de umidade inicial (base úmida), por 15 dias a $45^{\circ} \mathrm{C}$. O estoque foi mantido a temperatura ambiente.

Para o preparo do inóculo, um grama do meio de estoque contendo esporos do microrganismo foi suspenso em $100 \mathrm{~mL}$ de solução de $\mathrm{NaCl}(0,9 \%)$. Desse modo, a concentração de esporos na suspensão foi de $10^{9}$ esporos. $\mathrm{mL}^{-1}$.

\subsubsection{Meios de cultura}

Os meios para os cultivos em estado sólido foram feitos de combinações entre farelo de trigo $(\mathrm{T})$, farelo de soja $(\mathrm{S})$ e bagaço de cana-de-açúcar 'in natura' $(\mathrm{B})$. As composições estudadas foram: TB (10:90), TB (20:80), SB (10:90) e SB (20:80), sendo que as proporções referem-se à massa seca. 
O bagaço de cana-de-açúcar (Usina Iracema, Iracemápolis, SP) com umidade inicial de $50 \%$ foi armazenado a $-20^{\circ} \mathrm{C}$, a fim de evitar proliferação microbiana. Para utilização nos ensaios, o bagaço foi seco em estufa a $50^{\circ} \mathrm{C}$ e peneirado, selecionandose as partículas retidas entre peneiras de $10(2 \mathrm{~mm})$ e 20 mesh $(0,84 \mathrm{~mm})$.

O farelo de trigo (Anaconda Industrial e Agrícola de Cereais, São Paulo, SP) com $13 \%$ de umidade inicial e o farelo de soja (Coamo Agroindustrial Cooperativa, Campo Mourão, PR) com $11 \%$ de umidade inicial foram secos em estufa a $50^{\circ} \mathrm{C}$ e armazenados até o momento da utilização, quando foram peneirados em peneira de 8 $(2,38 \mathrm{~mm})$ e 20 mesh $(0,84 \mathrm{~mm})$, utilizando-se a fração retida entre as peneiras.

\subsubsection{Soluções Utilizadas}

- Solução salina conforme Urbánszki et al. (2000): 5 g.L ${ }^{-1} \mathrm{KH}_{2} \mathrm{PO}_{4} ; 5$ g.L ${ }^{-1}\left(\mathrm{NH}_{4}\right)_{2} \mathrm{SO}_{4} ; 1$ g.L $\mathrm{L}^{-1} \mathrm{MgSO}_{4} 7 \mathrm{H}_{2} \mathrm{O} ; 1 \mathrm{~g} \cdot \mathrm{L}^{-1} \mathrm{NaCl} ; 5,0 \mathrm{mg} \cdot \mathrm{L}^{-1} \mathrm{FeSO}_{4} 7 \mathrm{H}_{2} \mathrm{O} ; 1,6 \mathrm{mg} \cdot \mathrm{L}^{-1} \mathrm{MnSO}_{4} ; 3,45 \mathrm{mg} \cdot \mathrm{L}^{-1}$ $\mathrm{ZnSO}_{4} 7 \mathrm{H}_{2} \mathrm{O}$ e $2,0 \mathrm{mg} \cdot \mathrm{L}^{-1} \mathrm{CoCl}_{2} 6 \mathrm{H}_{2} \mathrm{O}$.

- Tampão acetato de sódio ( $\mathrm{pH} \mathrm{5,0):} \mathrm{Solução} \mathrm{composta} \mathrm{por} \mathrm{14,8} \mathrm{mL} \mathrm{de} \mathrm{solução} \mathrm{de}$ ácido acético $\left(11,55 \mathrm{~g} \cdot \mathrm{L}^{-1}\right), 35,2 \mathrm{~mL}$ de solução de acetato de sódio $\left(27,2 \mathrm{~g} \cdot \mathrm{L}^{-1}\right)$ e água destilada até atingir um volume final de $100 \mathrm{~mL}$.

- Inibidor de bactérias: Solução de azida de sódio com concentração 80 g.L.1.

- Antifúngico: Solução de ciclohexano com concentração 10 g.L $\mathrm{L}^{-1}$.

\subsubsection{Cultivo em estado sólido em Frasco Erlenmeyer}

Os cultivos do fungo Myceliophthora sp. M77 foram realizados em frascos Erlenmeyer contendo $7 \mathrm{~g}$ de substrato, com umidade inicial corrigida pela adição de solução salina conforme descrita por Urbánszki et al. (2000). Os frascos foram esterilizados em autoclave a $121^{\circ} \mathrm{C}$ por $20 \mathrm{~min}$, inoculados com a suspensão de 
esporos diluída de modo a obter-se $10^{7}$ esporos.gms ${ }^{-1}$ e mantidos em estufa a $45^{\circ} \mathrm{C}$ por cinco dias, com amostragens nos dias 1, 2, 3 e 5 de cultivo. Os ensaios foram feitos em triplicata. As repetições foram realizadas desde o preparo do inóculo.

\subsubsection{Cultivo em estado sólido em reator tipo coluna de Raimbault}

Com o objetivo de realizar balanços de oxigênio dos cultivos em estado sólido, foram realizados ensaios com colunas de Raimbault.

Colunas de Raimbault são reatores de leito fixo dotados de aeração forçada pelo meio de cultura e controle de vazão de ar. As colunas têm $15 \mathrm{~cm}$ de altura e $5 \mathrm{~cm}$ de diâmetro. Realizando-se o cultivo de um conjunto de colunas idênticas entre si, cada coluna retirada representa uma amostra no instante da remoção.

As colunas foram preenchidas com $12 \mathrm{~g}$ (massa seca) de mistura de farelo de soja e bagaço de cana-de-açúcar na proporção 10:90 (massa seca). O substrato foi esterilizado em autoclave a $121^{\circ} \mathrm{C}$ por $20 \mathrm{~min}$. As colunas foram esterilizadas nas mesmas condições. O meio foi então inoculado com suspensão de esporos diluída de modo a obter-se $10^{7}$ esporos.gms ${ }^{-1}$. A quantidade de solução salina de Urbánszki et al. (2000) adicionada antes da autoclavagem somada aquela da suspensão do inóculo resultou um meio com umidade de $80 \%$ (base úmida). Após preenchimento com o substrato, as colunas foram conectadas a alimentação de ar e colocadas em banho de água a $45^{\circ} \mathrm{C}$. $\mathrm{O}$ ar de alimentação das colunas foi umidificado por um sistema que consistia em um frasco Erlenmeyer de $10 \mathrm{~L}$ contendo água destilada esterilizada através da qual o ar era borbulhado. O Erlenmeyer foi parcialmente preenchido com pequenas esferas de vidro com a finalidade de aumentar a superfície de contato entre ar e água. Após passar por este umidificador, o sistema de distribuição de ar era ramificado por meio de mangueiras, uma para cada coluna, cada mangueira se conectando a um copo encaixado na parte inferior da coluna que continha água destilada esterilizada. Cada copo era dotado de um filtro cerâmico, de tal modo que o ar borbulhava ao passar deste para a água do copo e então entrava na coluna (Figura 6). 
A vazão de alimentação de ar foi mantida em $150 \mathrm{~mL} \cdot \mathrm{min}^{-1}$ por coluna. A temperatura do ar na entrada da coluna era $45^{\circ} \mathrm{C}$.

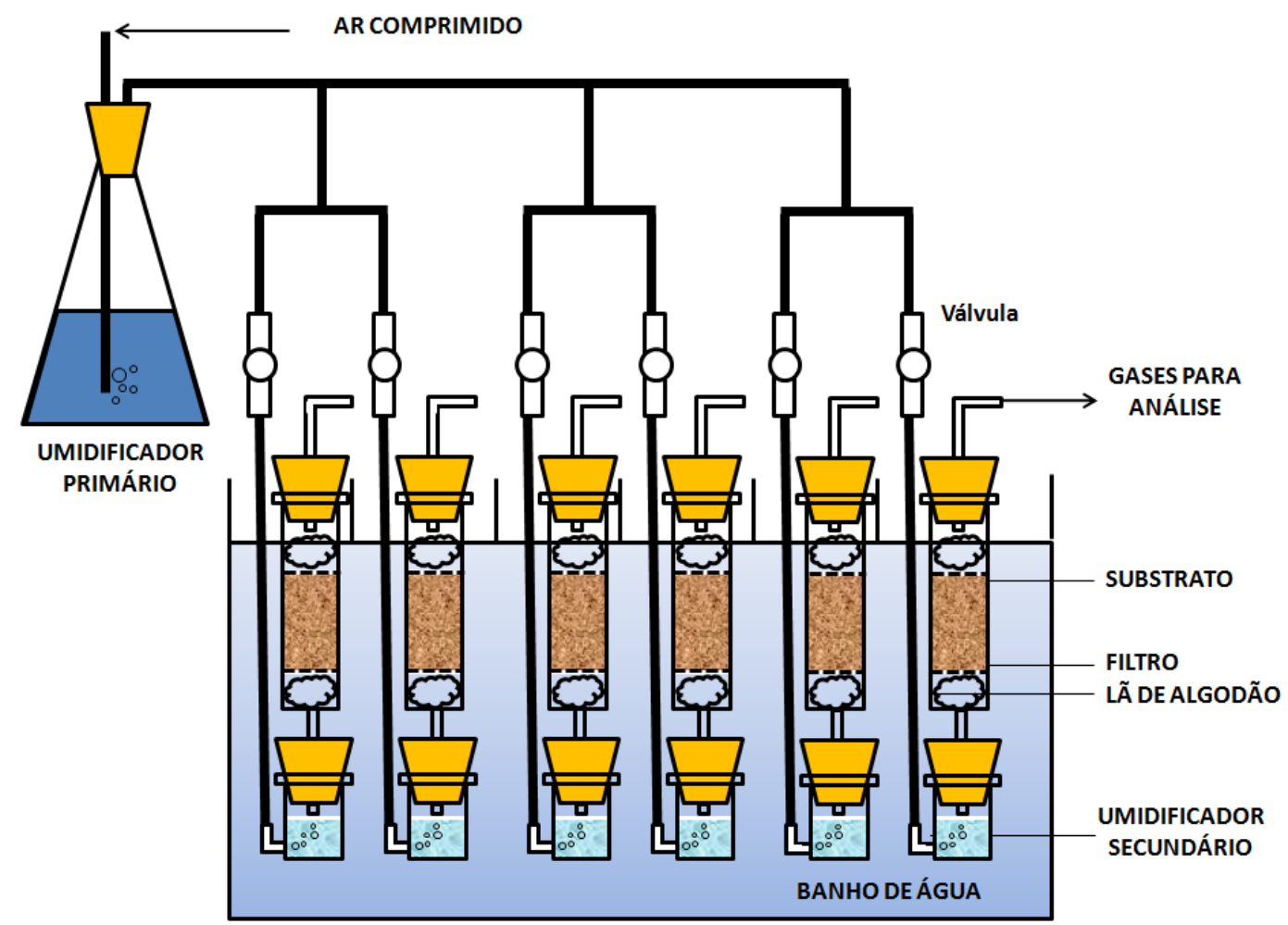

Figura 6 - Esquema dos ensaios em coluna de Raimbault

As concentrações de $\mathrm{O}_{2}$ e $\mathrm{CO}_{2}$ no gás de saída das colunas foram analisadas respectivamente com sensor de óxido de zircônio e de infravermelho em analisador de gases modelo EX-2000, New Brunswick Scientific Co (EUA). 


\subsubsection{Metodologia de Análise}

\subsubsection{Umidade}

A umidade foi determinada pelo aparelho OHAUS MB 35 Moisture Analyzer (EUA) que opera sobre o princípio termo-gravimétrico. A amostra é rapidamente aquecida por uma unidade de secagem de halogênio para evaporação da umidade. Ao final da secagem, o resultado é exibido como porcentagem de umidade em base úmida. Assim, neste trabalho, sempre que for citada a umidade, esta é dada em base úmida.

\subsubsection{Extração das enzimas}

O método de extração das enzimas consistiu em colocar em um frasco Erlenmeyer $4,0 \mathrm{~g}$ de meio cultivado, $40 \mathrm{~mL}$ de água destilada, $40 \mathrm{~mL}$ de tampão acetato de sódio $(\mathrm{pH} \mathrm{5,0)} \mathrm{e} 1$ gota do surfactante Tween 80. O frasco foi agitado em shaker na condição de $180 \mathrm{rpm}, \mathrm{T}=25^{\circ} \mathrm{C}$, por $60 \mathrm{~min}$. Em seguida, a amostra foi filtrada em gaze para retirada das partículas sólidas maiores e centrifugada por 15 min a 10000 rpm e $5^{\circ} \mathrm{C}$. O sobrenadante foi utilizado para determinação das atividades enzimáticas.

\subsubsection{Atividades enzimáticas e Produtividade da enzima}

Para os extratos enzimáticos produzidos por CES foram realizados três tipos de medidas de atividade enzimática: Atividade de Filter Paper (Papel de filtro), atividade de endoglicanase e atividade de xilanase. 
Para quantificar a atividade enzimática das enzimas comerciais foram realizadas a medida de atividade de Filter Paper para a enzima Celulase (Novozymes NS 50013, lote: CCN03102), a medida de atividade de celobiase para a enzima $\beta$-glicosidase (Novozymes NS 50010, lote: DCN00209) e a medida de atividade de xilanase para a enzima Xilanase (Novozymes NS 50030, lote: CDN00412).

A unidade de atividade enzimática (U) é definida como a quantidade de enzima que libera $1 \mu \mathrm{mol}$ de açúcares redutores em $1 \mathrm{~min}$. Os resultados foram expressos em U.gms $^{-1}$ (grama de massa seca). Para as atividades de papel de filtro e endoglicanase, o açúcar redutor equivale à glicose. Para a atividade de xilanase, o açúcar redutor equivale à xilose.

Como a atividade enzimática é expressa em relação a uma massa de meio de cultura, ela pode ser definida como a concentração de enzima no meio. Assim, neste trabalho, a concentração de celulase $\left(\mathrm{C}_{\mathrm{FPA}}\right)$ refere-se aos valores encontrados para a atividade de Filter Paper (FPU.gms $\left.{ }^{-1}\right)$. A produtividade em celulase $\left(P_{R}\right)$ é definida como a taxa de produção de celulase (FPU.gms ${ }^{-1} \cdot \mathrm{h}^{-1}$ ) e foi determinada dividindo-se o valor observado de concentração de celulase pelo tempo de cultivo necessário para atingir esse valor.

\subsubsection{Curva padrão de absorbância}

A curva padrão de absorbância foi realizada utilizando-se soluções de açúcar com concentrações conhecidas $\left(0,2,0,4,0,6,0,8\right.$ e 1,0 g. $\left.\mathrm{L}^{-1}\right)$.

Para as atividades de Filter Paper e endoglicanase, o açúcar utilizado foi a glicose enquanto que para a atividade de xilanase, o açúcar utilizado foi a xilose.

Em um tubo Follin-Wu adicionou-se 1,0 mL da solução de açúcar e 3,0 mL de solução de DNS. O tubo foi mergulhado em água fervente por 5 minutos e, logo após, mergulhado em banho de gelo. Completou-se o volume com água destilada até 12,5 mL. Após homogeneização da solução, realizou-se a leitura de absorbância a 540 nm. 
O procedimento foi feito em triplicata. Com esses dados, foi levantada a curva padrão de absorbância em função da concentração de açúcar.

O extrato enzimático foi diluído até a concentração de açúcar obtida pela leitura de absorbância estar na faixa linear conhecida da curva padrão de absorbância, que nesse caso foi de 0 a $1 \mathrm{~g} \cdot \mathrm{L}^{-1}$.

\subsubsection{Atividade de Filter Paper}

A produção de celulases foi avaliada com base na atividade enzimática sobre papel de filtro (Atividade de 'Filter Paper' - FPA). A metodologia foi realizada conforme descrita por Ghose (1987).

Colocou-se um pedaço de papel de filtro Whatman $\mathrm{N}^{\circ} 1$ de $1,0 \times 6,0 \mathrm{~cm}$ em tubo Follin-Wu e adicionou-se $1,5 \mathrm{~mL}$ do extrato de enzima diluído em tampão acetato de sódio. Este conjunto foi mantido em banho de água a $50^{\circ} \mathrm{C}$ por $60 \mathrm{~min}$. A reação foi interrompida pela adição de $3 \mathrm{~mL}$ de solução de DNS ao tubo, que então foi levado a um banho de água fervente por $5 \mathrm{~min}$ e, logo em seguida, a um banho de gelo. $\mathrm{O}$ volume reacional foi ajustado com água destilada para $12,5 \mathrm{~mL}$ e a absorbância da mistura foi determinada a $540 \mathrm{~nm}$.

Para quantificar a concentração de açúcares presente no extrato enzimático foi feito um branco de enzima para cada amostra. Adicionou-se 1,5 $\mathrm{mL}$ do extrato de enzima diluído em tampão acetato de sódio e $3 \mathrm{~mL}$ de DNS em um tubo de Follin-Wu. O tubo foi deixado em banho de água fervente por 5 minutos, seguido de banho de gelo. O volume foi completado com água destilada para $12,5 \mathrm{~mL}$, o tubo foi vertido e a absorbância da mistura lida a $540 \mathrm{~nm}$. O branco do espectro para as leituras foi realizado seguindo o mesmo procedimento, porém, substituindo-se a solução de enzima diluída por 1,5 mL de tampão acetato de sódio. 


\subsubsection{Atividade de endoglicanase}

A metodologia de atividade de endoglicanase foi realizada conforme Ghose (1987). O reagente utilizado foi uma solução $2 \%$ (massa) de carboximetil-celulose (Carboximetil-celulose sódica de baixa concentração, SIGMA-ALDRICH) em tampão acetato de sódio. Em um tubo Follin-Wu adicionou-se 0,5 mL dessa solução e 0,5 mL de extrato enzimático diluído em tampão acetato de sódio. Essa mistura foi deixada em um banho a $50^{\circ} \mathrm{C}$ por 30 minutos. Após o tempo de reação, acrescentou-se $3 \mathrm{~mL}$ de solução de DNS e o tubo foi então levado a um banho de água fervente por 5 minutos e logo em seguida, mergulhado em um banho de gelo para cessar a reação. O volume foi ajustado com água destilada em 12,5 mL e a absorbância da mistura foi lida a $540 \mathrm{~nm}$.

Para o branco de enzima, $0,5 \mathrm{~mL}$ da solução $2 \%$ de carboximetil-celulose em tampão acetato de sódio foi deixado em banho a $50^{\circ} \mathrm{C}$ por $30 \mathrm{~min}$. Logo em seguida acrescentou-se $3 \mathrm{~mL}$ de DNS e 0,5 mL do extrato enzimático diluído em tampão acetato de sódio, e essa mistura foi levada a banho de água fervente por 5 minutos, seguido de banho de gelo. Após ajuste do volume com água destilada para 12,5 mL, a absorbância foi lida em $540 \mathrm{~nm}$. Para o branco do espectro foi realizado o mesmo procedimento, porém, substituindo o extrato enzimático por tampão acetato de sódio.

\subsubsection{Atividade de Xilanase}

A metodologia de atividade de xilanase é semelhante à metodologia aplicada para a atividade de endoglicanase. As diferenças são o tempo de reação, que para essa metodologia é de 20 minutos ao invés de 30 minutos, e o reagente utilizado para a reação, que nesse caso é uma solução 1\% (massa) de xilana (Xilana obtida de aveia, SIGMA-ALDRICH) em tampão acetato de sódio. Assim, foram realizados os mesmos procedimentos adotados para a metodologia de atividade de endoglicanase, 
substituindo-se o tempo de reação e o reagente empregado. Essa substituição também foi empregada na medida do branco de enzima e do branco de espectro.

\subsubsection{Atividade de Celobiase}

A metodologia aplicada foi a mesma utilizada para as medições de atividade de endoglicanase e atividade de xilanase. Porém, o tempo reacional adotado foi de 30 minutos e o reagente foi uma solução $15 \mathrm{mM}$ de celobiose $(\mathrm{D}(+)$ celobiose mínimo 98\%, SIGMA-ALDRICH) em tampão acetato de sódio.

\subsubsection{Análise do gás de saída dos reatores tipo coluna de Raimbault}

A velocidade de consumo de $\mathrm{O}_{2}$, OUR, a velocidade de produção de $\mathrm{CO}_{2}, \mathrm{CER}$, dos ensaios em reatores tipo coluna de Raimbault foram calculados através de balanços materiais de $\mathrm{O}_{2}$ e $\mathrm{CO}_{2}$ e determinados pelas seguintes equações:

$$
\begin{gathered}
\text { OUR }=\frac{\left(P_{a t m}-P_{\mathrm{H}_{2} \mathrm{O}}\right) \cdot\left(Y_{\mathrm{O}_{2} \text { Saida }}-Y_{\mathrm{O}_{2} \text { Entrada }}\right)}{R \cdot T} \cdot F_{a r} \\
C E R=\frac{\left(P_{a t m}-P_{\mathrm{H}_{2} \mathrm{O}}\right) \cdot\left(Y_{\mathrm{CO}_{2} \text { Saida }}-Y_{\mathrm{CO}_{2} \text { Entrada }}\right)}{R \cdot T} \cdot F_{a r}
\end{gathered}
$$

Sendo,

OUR - Velocidade de consumo de oxigênio $\left(\mathrm{mol} \mathrm{O}_{2} \cdot \mathrm{h}^{-1}\right)$

CER - Velocidade de produção de dióxido de carbono $\left(\mathrm{mol} \mathrm{CO}_{2} \cdot \mathrm{h}^{-1}\right)$

$\mathrm{F}_{\mathrm{ar}}$ - Vazão molar de ar na entrada no reator $\left(\mathrm{mol}^{\mathrm{h}} \mathrm{h}^{-1}\right)$

$\mathrm{R}$ - Constante universal dos gases $\left(62,361 \mathrm{mmHg} \cdot \mathrm{K}^{-1} \cdot \mathrm{mol}^{-1}\right)$ 
$\mathrm{T}$ - Temperatura $(\mathrm{K})$

$P_{\text {atm }}$ - Pressão atmosférica local, em São Paulo $(690$ mmHg)

$\mathrm{P}_{\mathrm{H} 2 \mathrm{O}}$ - Pressão de vapor da água a $45^{\circ} \mathrm{C}(72 \mathrm{mmHg})$

$\mathrm{Y}_{\mathrm{O} 2}$ - Fração molar de $\mathrm{O}_{2}$ (na entrada e na saída do reator)

$\mathrm{Y}_{\mathrm{CO} 2}$ - Fração molar de $\mathrm{CO}_{2}$ (na entrada e na saída do reator)

\subsection{ENSAIOS DE HIDRÓLISE COM ENZIMAS PRODUZIDAS POR CES}

\subsubsection{Substrato}

Foram utilizados dois tipos de bagaço de cana-de-açúcar pré-tratado além do bagaço 'in natura': bagaço pré-tratado por explosão a vapor e bagaço pré-tratado por diferentes doses de radiação ionizante, 30, 70 e 150 kGy. Uma vez que os bagaços são armazenados secos, antes dos ensaios de hidrólise os bagaços foram submetidos à hidratação com água destilada por um "overnight" e em seguida, filtrados sob vácuo.

\subsubsection{Ensaios de Hidrólise}

Todos os ensaios de hidrólise seguiram a seguinte metodologia.

Uma massa de $1 \mathrm{~g}$ de bagaço pré-tratado (pré-tratamentos específicos) foi colocada em Erlenmeyer de $250 \mathrm{~mL}$ ao qual se adicionaram as enzimas, $80 \mu \mathrm{L}$ de inibidor de bactérias e $60 \mu \mathrm{L}$ de antifúngico. O volume foi completado com tampão acetato de sódio até atingir concentração final de sólidos de 1\%.

Os frascos foram tampados com rolhas e colocados em shaker (180 rpm) a uma determinada temperatura, dependendo do tipo de ensaio realizado. Amostras foram 
tiradas a diferentes intervalos de tempo, centrifugadas, filtradas e congeladas para posterior análise.

Foram realizados diferentes tipos de ensaios de hidrólise.

\subsubsection{Ensaios de Hidrólise com bagaço submetido a diferentes pré-tratamentos}

Foram realizados ensaios de hidrólise com enzimas produzidas por CES utilizando-se bagaços de cana-de-açúcar submetidos a diferentes pré-tratamentos. Também foram realizados ensaios de hidrólise com enzimas comerciais, para comparação com o desempenho das enzimas produzidas por CES. Os ensaios foram realizados a $50^{\circ} \mathrm{C}$.

Utilizaram-se as seguintes enzimas:

- Celulase: Novozymes NS 50013, lote: CCN03102, 82,2 FPU.mL ${ }^{-1}$.

- $\beta$-glicosidase: Novozymes NS 50010, lote: DCN00209, 300 U.mL -1 $^{-1}$

- Xilanase: Novozymes NS 50030, lote: CDN00412, 896,8 U. $\mathrm{mL}^{-1}$.

- Extrato de enzimas produzidas pelo fungo Myceliophthora sp. M77 em meio composto por bagaço de cana-de-açúcar e farelo de trigo na proporção 60:40, cultivado a temperatura de $45^{\circ} \mathrm{C}$ por dois dias, 0,055 FPU. $\mathrm{mL}^{-1}$.

A atividade específica das enzimas adicionadas em cada ensaio em relação à massa de substrato é apresentada na Tabela 4 (em unidades por grama de massa seca de bagaço pré-tratado). Os ensaios de hidrólise com enzimas produzidas por CES foram suplementados com $\beta$-glicosidase e xilanase comercial, pois o extrato de CES possui baixa atividade para essas enzimas. 
Tabela 4 - Atividade específica das enzimas adicionadas nos ensaios de hidrólise de bagaço de cana-deaçúcar pré-tratado.

\begin{tabular}{|c|c|c|}
\hline Enzima & $\begin{array}{c}\text { Hidrólise com } \\
\text { enzimas de CES }\end{array}$ & $\begin{array}{c}\text { Hidrólise com } \\
\text { enzimas comerciais }\end{array}$ \\
\hline Celulase (Novozymes) & ---- & $10 \mathrm{FPU} \mathrm{gms}^{-1}$ \\
\hline$\beta$-glicosidase (Novozymes) & 15 U.gms $^{-1}$ & 15 U.gms $^{-1}$ \\
\hline Xilanase (Novozymes) & 2000 U.gms $^{-1}$ & 2000 U.gms $^{-1}$ \\
\hline Extrato de CES & $10 \mathrm{FPU} \mathrm{gms}^{-1}$ & --- \\
\hline
\end{tabular}

\subsubsection{Hidrólise enzimática a diferentes temperaturas}

Para avaliar a melhor temperatura de hidrólise assim como a estabilidade térmica das enzimas produzidas pelo fungo termofílico Myceliophthora sp. M77 foram realizados ensaios de hidrólise a diferentes temperaturas. Para esses ensaios foi utilizado extrato enzimático produzido por CES de Myceliophthora sp. M77 em meio composto por farelo de soja e bagaço de cana-de-açúcar na proporção 10:90 e umidade inicial de 60\%. O cultivo foi realizado a $45^{\circ} \mathrm{C}$ por três dias. Os ensaios foram realizados a $50{ }^{\circ} \mathrm{C}, 60{ }^{\circ} \mathrm{C}$ e $70{ }^{\circ} \mathrm{C}$. O material utilizado foi o bagaço de cana-de-açúcar pré-tratado por explosão a vapor. A dosagem de enzimas adicionadas foi de $10 \mathrm{FPU} \mathrm{gms}^{-1}$. Os ensaios foram realizados em triplicata desde a produção das enzimas por CES.

\subsubsection{Hidrólise enzimática com ou sem extração de enzimas}

Avaliou-se a hipótese de realizar o ensaio de hidrólise enzimática sem a extração prévia das enzimas do fermentado sólido. Nestes ensaios uitilizou-se como substrato celulose cristalina (MC201, MICROCEL) e bagaço de cana-de-açúcar pré-tratado por explosão a vapor. A carga enzimática utilizada (por grama de celulose) foi de $10 \mathrm{FPU}$ de celulase produzida por CES. Foram realizados ensaios com suplementação de $15 \mathrm{U}$ 
de $\beta$-glicosidase comercial (Novozymes NS 50010, lote: DCN00209, $300 \mathrm{U} / \mathrm{mL}$ ) e ensaios sem suplementação dessa enzima.

Utilizou-se as enzimas produzidas por Myceliophthora sp. M77 em meio sólido SB (10:90) com $80 \%$ de umidade inicial, cultivado em estufa a $45^{\circ} \mathrm{C}$ por 5 dias.

Para os ensaios de hidrólise com extrato enzimático (HEx), as celulases utilizadas encontravam-se no líquido extraído do meio de cultura. Assim, foi utilizado um determinado volume de extrato enzimático de maneira a alcançar uma carga enzimática de 10 FPU.(gms celulose $)^{-1}$.

Denominou-se HAd os ensaios de hidrólise com enzimas aderidas ao meio de cultura, ou seja, para esses ensaios não houve extração das enzimas do meio de cultura sólido. Neste caso, acrescentou-se ao substrato o próprio meio de cultura cultivado por 5 dias em quantidade suficiente para atingir a carga enzimática de 10 FPU. (gms celulose) ${ }^{-1}$.

Foi realizado um ensaio para verificar se o meio de cultura formado de bagaço de cana e farelo de soja influenciou a reação de hidrólise mesmo após ser fermentado, ou seja, se o meio de cultura participou da reação como substrato. Esse ensaio foi denominado Ensaiod de Referência. Em um Erlenmeyer acrescentou-se uma massa de meio de cultura cultivado por 5 dias contendo 10 FPU de celulases e tampão acetato de sódio até atingir $1 \%$ de sólidos. Após $48 \mathrm{~h}$ no shaker a $180 \mathrm{rpm} \mathrm{e} 50^{\circ} \mathrm{C}$, uma amostra foi coletada para análise dos açúcares liberados.

Todos os ensaios foram realizados em triplicata. 


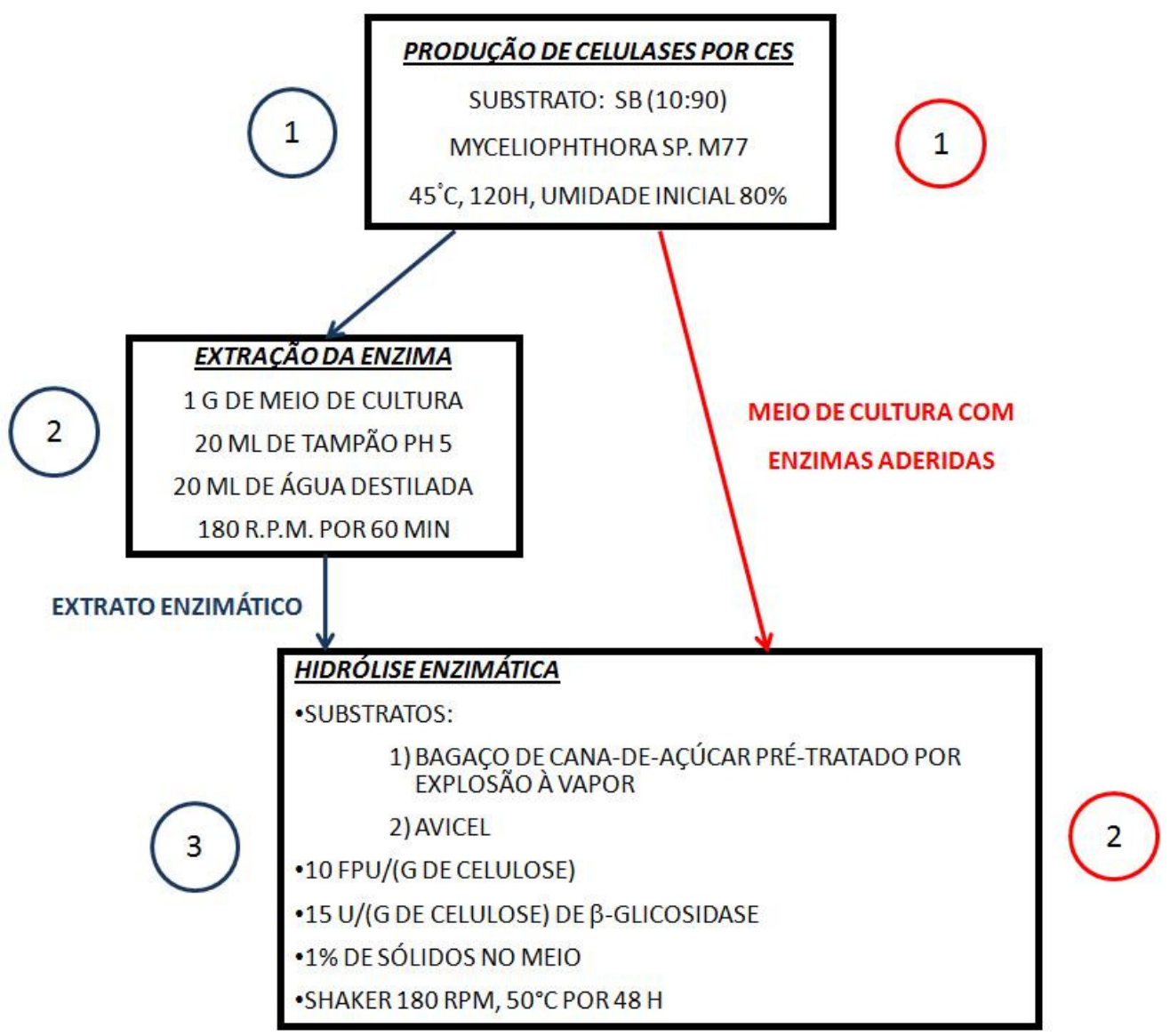

Figura 7 - Esquema dos ensaios de hidrólise com e sem extração de enzimas porduzidas por CES.

\subsubsection{Análise de açúcares}

As amostras da hidrólise foram analisadas em HPLC (Waters, EUA) com detector de índice de refração e coluna Shodex Sugar SP0810 nas seguintes condições: temperatura da coluna de $80^{\circ} \mathrm{C}, \mathrm{H}_{2} \mathrm{O}$ deionizada como fase móvel na vazão de 0,5 $\mathrm{mL} \cdot \mathrm{min}^{-1}$. Os açúcares analisados foram: glicose, celobiose e xilose. 


\subsubsection{Cálculo de conversão de celulose em glicose}

O cálculo da conversão de celulose em glicose $(X)$ foi feito a partir da equação abaixo:

$$
X(\%)=C_{\text {Glicose }}\left(\frac{g}{L}\right) \cdot \frac{V_{\text {Tampão }}(L)}{m_{\text {hidrolisável }}(g)} \cdot \frac{1}{f\left(\frac{g \text { celulose }}{g \text { hidrolisável }}\right)} \cdot F E \cdot 100
$$

Onde $C_{\text {Glicose }}$ é a concentração de glicose obtida na hidrólise, $V_{\text {Tampão é o volume }}$

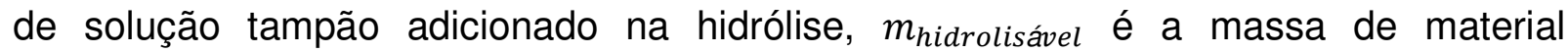
hidrolisável utilizada, f é a fração de celulose no material hidrolisável utilizado e FE é o fator estequiométrico da reação de celulose a glicose $(0,9)$.

As frações de celulose dos substratos bagaço de cana-de-açúcar in natura, bagaço de cana-de-açúcar tratado por radiação ionizante (30, 70 ou 150 kGy), bagaço de cana-de-açúcar pré-tratado por explosão à vapor e celulose cristalina correspondem a $0,43,0,42,0,49$ e 1 , respectivamente (dados dos fornecedores). 


\section{RESULTADOS E DISCUSSÃO}

\subsection{PRODUÇÃO DE CELULASES POR CULTIVO EM ESTADO SÓLIDO (CES)}

4.1.1 Avaliação de meios de cultura na produção de celulases por Myceliophthora sp. M77 em CES

Meios de cultura formados principalmente por bagaço de cana-de-açúcar foram avaliados na produção de celulases por Myceliophthora sp. M77 cultivado em meio sólido.

A Figura 8 apresenta a cinética de produção de celulases expressa em

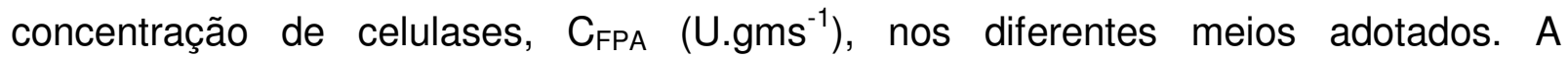
composição em massa e a umidade inicial em base úmida de cada cultivo estão descritos na legenda. 


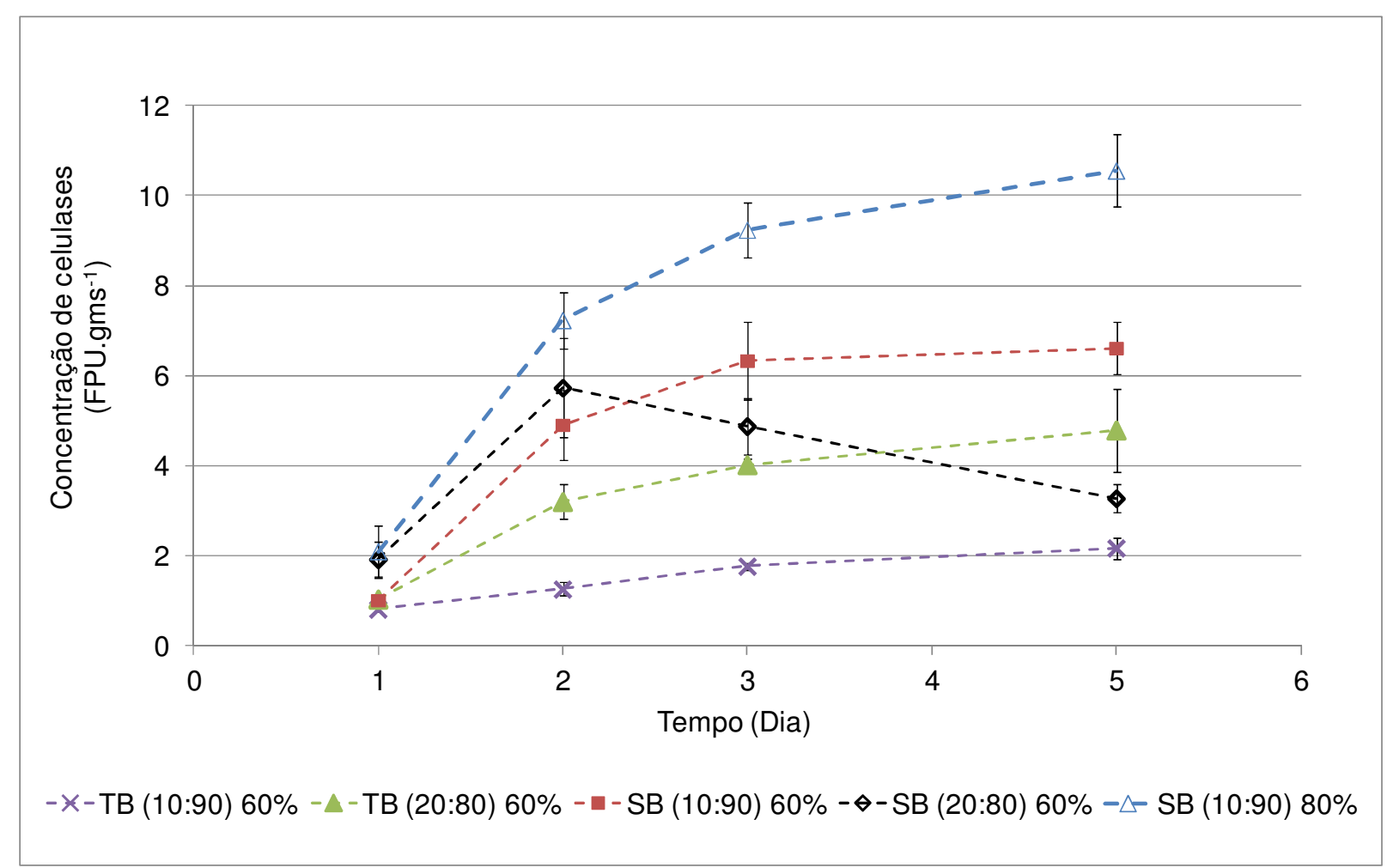

Figura 8 - Concentração de celulases ao longo do tempo para cultivos de Myceliophthora sp. M77, em frascos Erlenmeyer, em meios de cultura constituídos de TB (10:90) 60\%, TB (20:80) 60\%, SB (10:90) $60 \%$, SB (20:80) $60 \%$ e SB (10:90) $80 \%$.

Primeiramente, serão analisados os cultivos cujos meios tinham $60 \%$ de umidade no instante inicial. Para esses cultivos, quando o meio de cultura continha farelo de trigo, o aumento da porcentagem de bagaço de cana-de-açúcar de $80 \%$ para $90 \%$ foi prejudicial para a produção das celulases, pois, verificou-se redução de $54 \%$ na concentração de celulases. Assim é que a concentração de celulases de $4,8 \pm 0,9$ FPU.gms ${ }^{-1}$ alcançada com o meio TB $(20: 80)$ caiu para 2,2 $\pm 0,3$ FPU.gms ${ }^{-1}$ no cultivo com o meio TB (10:90), sendo ambos os valores tomados no quinto dia de cultivo.

Pela análise dos cultivos com farelo de soja em meio com $60 \%$ de umidade inicial tem-se que o máximo valor de $\mathrm{C}_{\mathrm{FPA}}$ observado para o meio $\mathrm{SB}(20: 80)$ foi de $5,7 \pm 1,1 \mathrm{FPU} \mathrm{gms}^{-1}$, no segundo dia de cultivo. A redução da concentração de celulases para a produção nesse meio, observada a partir de 48h de cultivo, provavelmente se deve à formação de proteases que podem degradar a celulase (HAAB et al., 1990). Esse comportamento pode ser atribuído à alta quantidade de proteína encontrada no farelo de soja a qual induz a síntese de proteases. Para os meios com farelo de trigo não foi verificada tal redução, mesmo para o cultivo com $20 \%$ em massa. Segundo os 
fornecedores, o farelo de soja possui $46 \%$ de proteína em sua composição contra $17 \%$ do farelo de trigo (porcentagem em massa). Já para o meio com apenas $10 \%$ de farelo de soja, SB (10:90), não ocorreu tal redução da concentração de celulases, mesmo em cinco dias de cultivo. Como observado na Figura 8, a concentração de celulases para esse meio atingiu o seu máximo no terceiro dia de cultivo, 6,3 $\pm 0,9 \mathrm{FPU}_{\mathrm{gms}}{ }^{-1}$, e permaneceu praticamente constante até o quinto dia.

Os cultivos da Myceliophthora sp. M77 em meio SB (10:90) e SB (20:80) a 60\% de umidade inicial resultaram concentrações de celulase maiores do que em meio TB, nas mesmas proporções, como indicado pela Figura 8. Portanto, farelo de soja é melhor que farelo de trigo para produção de celulases por Myceliophthora sp. M77, resultado que também pode ser atribuído ao maior teor de proteína no farelo de soja, o que, provavelmente, aumenta o crescimento e síntese protéica.

Embora o preço do farelo de soja no mercado brasileiro seja maior do que o preço do farelo de trigo - aproximadamente $R \$ 650,00 /$ ton contra $R \$ 335,00 /$ ton (Corrretora Mercado), respectivamente - a substituição do farelo de trigo pelo farelo de soja no meio formado por $90 \%$ de bagaço de cana-de-açúcar resultou numa produção de celulases três vezes maior, no quinto dia de cultivo.

A elevação da umidade inicial do meio SB (10:90) de $60 \%$ para $80 \%$ resultou uma concentração de celulases $68 \%$ maior no quinto dia de cultivo, passando de $6,3 \pm 0,6 \mathrm{U} . g m s^{-1}$ para $10,6 \pm 0,8 \mathrm{U} . g m s^{-1}$, a maior produção entre todos os resultados apresentados.

Um fator importante quanto ao custo final da enzima é a produtividade. A Figura 9 apresenta a produtividade em celulase $\left(P_{R}\right)$ no instante de máxima concentração de celulases alcançada em cada cultivo. 


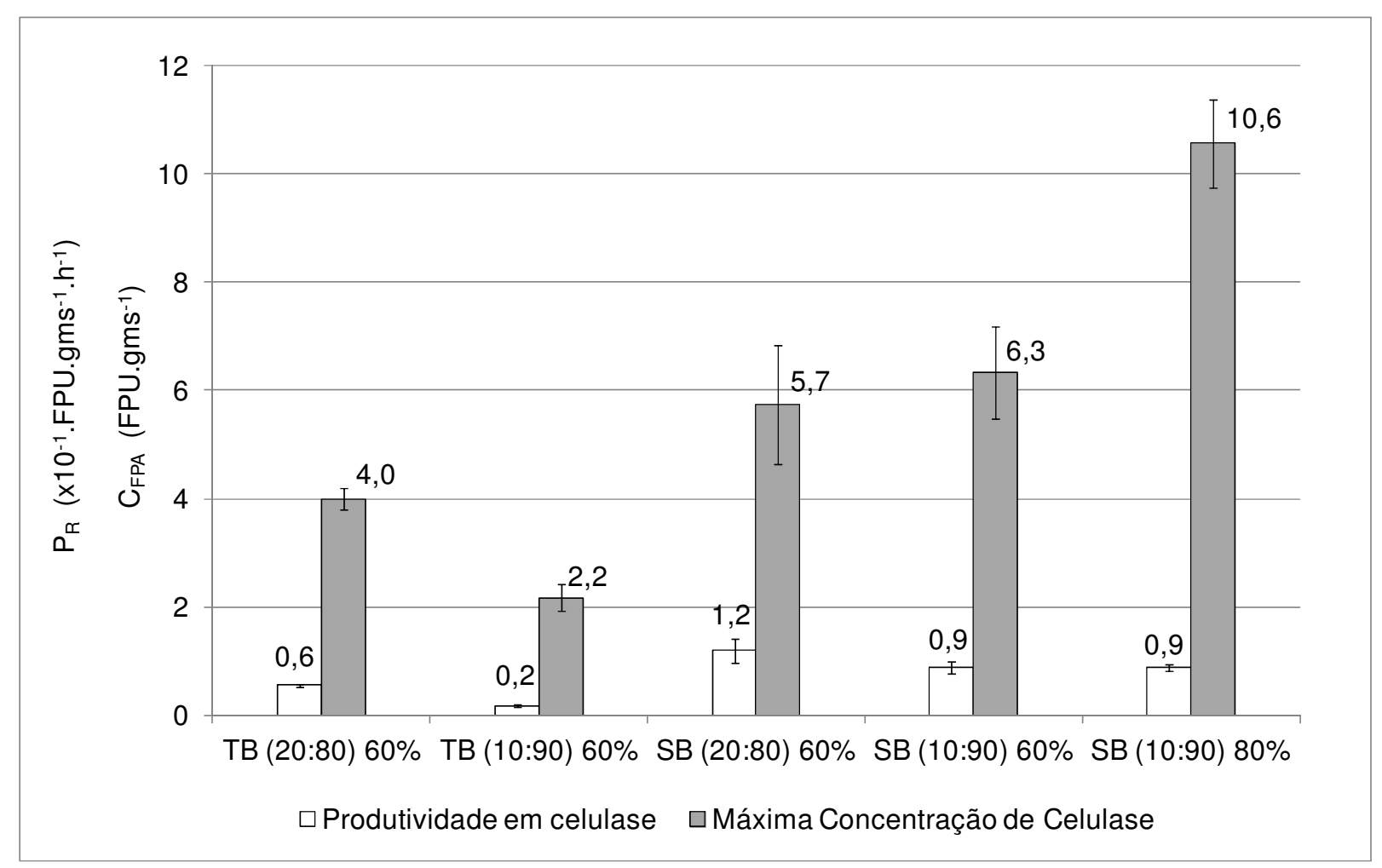

Figura 9 - Produtividade em celulase em relação à máxima concentração de celulases nos cultivos de Myceliophthora sp. M77 em meios de cultura constituídos de TB (20:80), TB (10:90), SB (20:80) e SB (10:90), todos com umidade inicial de $60 \%$, e meio SB (10:90), com umidade inicial de $80 \%$.

Observa-se que os cultivos em meio composto por farelo de soja apresentaram maiores produtividades. O cultivo em meio SB (10:90) com umidade $80 \%$ além de apresentar a maior concentração de celulase, também apresentou uma das maiores produtividades, $0,09 \pm 0,01 \mathrm{FPU} \cdot \mathrm{gms}^{-1} \cdot \mathrm{h}^{-1}$. Com base nesses resultados é possível concluir que o farelo de soja é um bom substrato para produção de celulases também quanto ao quesito produtividade, o qual é importante no custo de produção de enzima.

Além da produtividade no instante de máxima concentração de celulases, é importante analisar o comportamento desta variável ao longo do cultivo, visto que ocorre significativa redução da velocidade de produção, conforme indicado na Figura 8.

A Figura 10 apresenta a produtividade em celulase ao longo do cultivo de Myceliophthora sp. M77 nos diferentes substratos. 


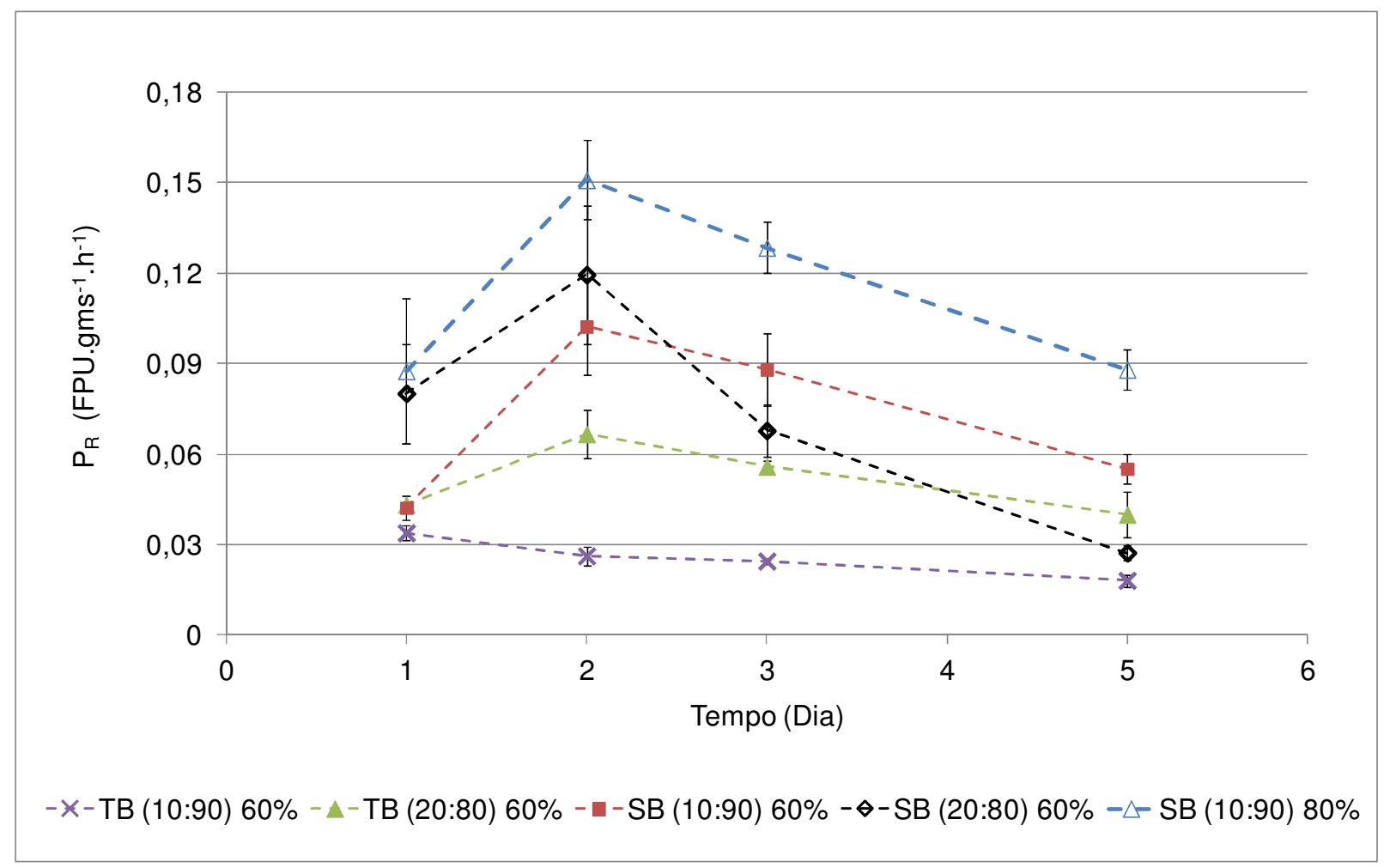

Figura 10 - Produtividade em celulase ao longo do tempo para cultivos de Myceliophthora sp. M77, em frascos Erlenmeyer, em meios de cultura constituídos de TB (10:90) 60\%, TB (20:80) 60\%, SB (10:90) $60 \%$, SB $(20: 80) 60 \%$ e SB $(10: 90) 80 \%$.

Pela análise da Figura 10, observa-se que com exceção do cultivo em meio TB $(10: 90) 60 \%$ que apresentou produtividades baixas durante todo o cultivo, todos os outros cultivos apresentaram máxima produtividade de celulases em $48 \mathrm{~h}$, e que a partir desse instante, a produtividade decresce. Tem-se que a maior produtividade foi alcançada para o cultivo em meio SB (10:90) 80\%, 0,15 $\pm 0,01 \mathrm{FPU} . \mathrm{gms}^{-1} \cdot \mathrm{h}^{-1}$, aumento de quase $70 \%$ em relação à produtividade desse meio no instante de máxima $\mathrm{C}_{\mathrm{FPA}}$, $0,09 \pm 0,01 \mathrm{FPU} \cdot \mathrm{gms}^{-1} \cdot \mathrm{h}^{-1}$.

Embora a redução de atividade enzimática ao longo do tempo de cultivo seja uma observação comum durante a produção de celulases, este comportamento não está completamente esclarecido. Segundo Liu e Yang (2007), a redução da atividade enzimática ao longo do cultivo pode ser devido à desnaturação da enzima, resultante, por exemplo, da variação do pH. Dillon et al. (2011) sugerem que a diminuição da atividade pode ser causada pela ação de proteases sobre a estabilidade da celulase ou a presença de inibidores, como glicose e celobiose, que interferem na medida de 
atividade de celulase. Sabe-se que a produção de celulases está associada ao crescimento (SINGHANIA et al., 2010), portanto, a diminuição da velocidade de acúmulo de celulases pode estar relacionada a algum fator que limita o crescimento como, por exemplo, a dificuldade de transferência de oxigênio no meio em cultivos em frascos Erlenmeyer e a limitação difusional das enzimas secretadas pelo fungo, que pode ser causada pela mudança de reologia do material, pela redução da atividade de água do meio de cultura, entre outros fatores.

Os resultados de $\mathrm{C}_{\mathrm{FPA}}$ e $\mathrm{P}_{\mathrm{R}}$ obtidos neste trabalho são similares aos apresentados por Badhan et al. (2007) para cultivo de Myceliophtora sp. IMI 387099 em palha de arroz (10,3 FPU.gms ${ }^{-1}$ e 0,08 FPU.gms ${ }^{-1} \cdot \mathrm{h}^{-1}$ ), porém, inferiores aos dados publicados na literatura para outros microrganismos. Dillon et al. (2005) registraram uma produção de celulase de 32,9 FPU.gms ${ }^{-1}$ para CES de Penicillium echinulatum 9A02S1 em meio composto por bagaço de cana-de-açúcar pré-tratado e farelo de trigo, sendo que a produtividade foi de 0,46 FPU.gms ${ }^{-1} \cdot \mathrm{h}^{-1}$. Mekala et al. (2008) otimizaram a produção de celulases por Trichoderma reesei Rut-C30 em bagaço de cana-de-açúcar através da adição de indutor de celulases no meio, registrando valores para $C_{F P A}$ e $P_{R}$ de 24,15 FPU.gms ${ }^{-1}$ e 0,35 FPU.gms ${ }^{-1} \cdot h^{-1}$, respectivamente.

Uma discussão mais aprofundada sobre as possíveis razões para tais diferenças de produção de celulases, assim como, a comparação dos resultados obtidos nesse trabalho com outros resultados gerados pelo estudo de produção de celulases em CES pelo GEnBio/EPUSP encontram-se no artigo "Microorganisms and media for cellulase production in solid state cultures”, Kilikian et al.(2012), submetido para publicação (Vide Apêndice).

Como a maior concentração de celulases foi alcançada para o meio SB (10:90) com $80 \%$ de umidade inicial, optou-se por determinar a atividade enzimática da endoglicanase e da xilanase para esse cultivo. Os resultados estão apresentados na Figura 11. 


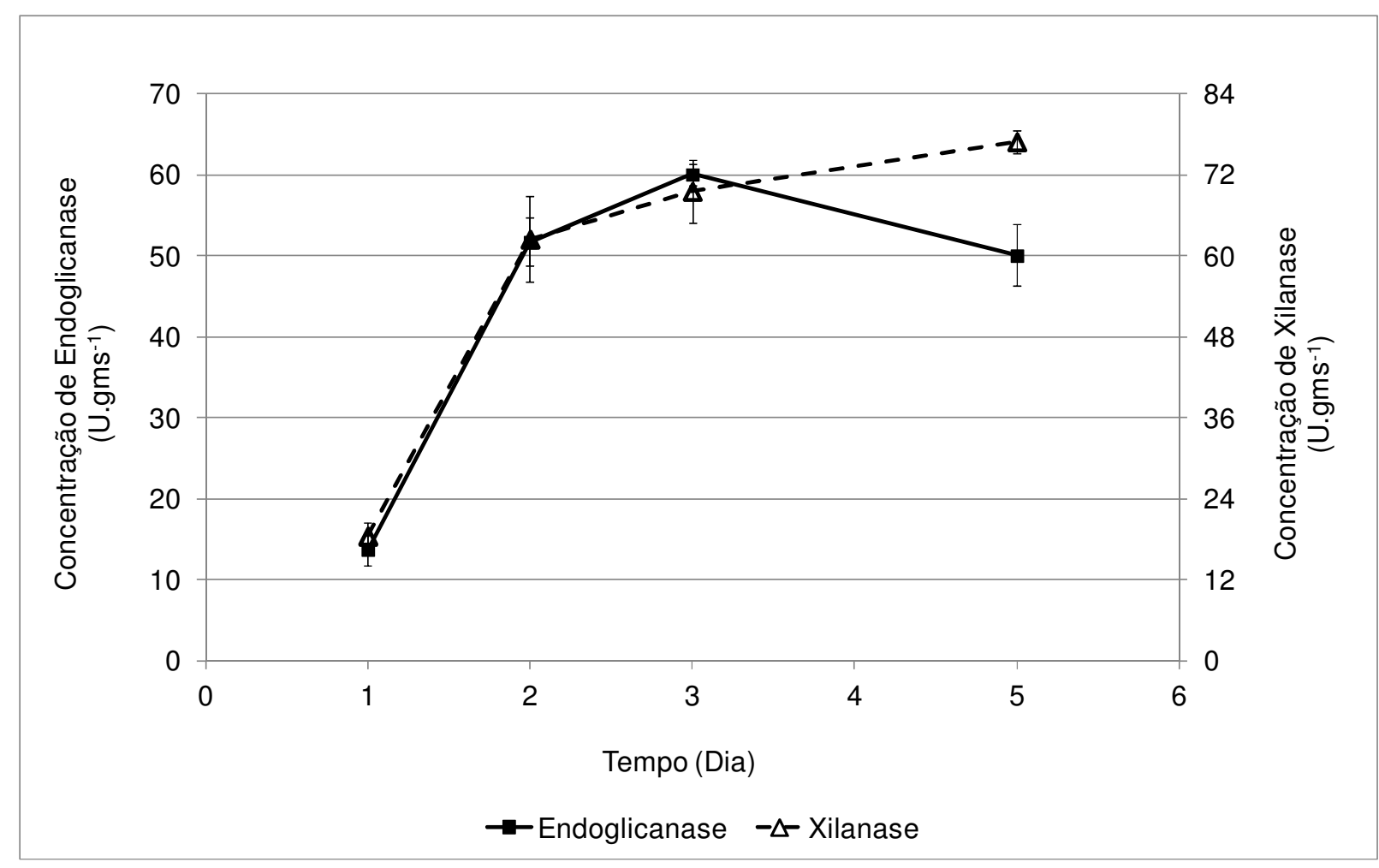

Figura 11 - Concentração de endoglicanase e de xilanase ao longo do tempo de cultivo de Myceliopthora sp. M77 em meio SB (10:90) com umidade inicial de $80 \%$.

Pela análise da Figura 11, a atividade máxima de endoglicanase foi observada no terceiro dia de cultivo, $60 \mathrm{U.gms}^{-1}$. Este valor encontra-se na faixa dos valores reportados na literatura para CES de Myceliophthora sp. Badhan et al. (2007) reportam valor de 42 U.gms $^{-1}$ e Moretti (2010), que também trabalhou com o fungo Myceliophthora sp. M77, reporta produção de $54 \mathrm{U} . g m s^{-1}$ de endoglicanase em meio composto de bagaço de cana-de-açúcar e farelo de trigo após oito dias de cultivo.

Já os valores determinados para atividade de xilanase são inferiores aos

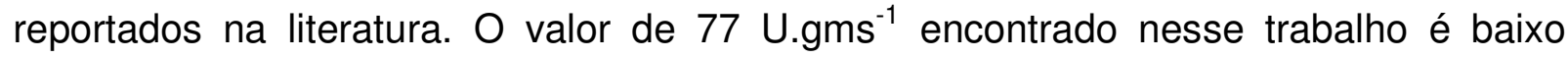
comparado a 2366 U.gms $^{-1}$ e 1045 U.gms $^{-1}$ reportados por Badhan et al. (2007) e Moretti (2010), respectivamente. Porém, cabe salientar que os métodos adotados para a quantificação tanto da atividade de endoglicanase quanto da atividade de xilanase são diferentes entre os autores. Dificultando, portanto, a comparação de resultados. 


\subsubsection{Cultivos de Myceliophthora sp. M77 em coluna de Raimbault}

Com o objetivo de estimar o crescimento celular, realizaram-se cultivos em reatores de leito fixo do tipo coluna de Raimbault, com aeração forçada e balanço gasoso, para estimativa da variação da biomassa com base no consumo de oxigênio. De posse de valores de concentração de biomassa, ainda que estimados, far-se-ia a correlação entre crescimento celular e produção de celulases. Além disso, a aeração forçada possibilitaria o crescimento celular em meio à uma disponibilidade de oxigênio maior que nos cultivos estáticos em frascos Erlenmeyer.

Foram realizados dois ensaios de cultivo de Myceliophthora sp. M77 em meio composto por farelo de soja e bagaço de cana-de-açúcar na proporção (10:90) e umidade inicial de $80 \%$. Determinou-se OUR e CER com base em dados de análise dos gases de saída das colunas. A vazão de ar foi de $150 \mathrm{~mL} \cdot \mathrm{min}^{-1}$ por coluna. Os resultados para OUR e CER ao longo do tempo de cultivo são apresentados na Figura 12, e os resultados de concentração de celulases na Figura 13. 

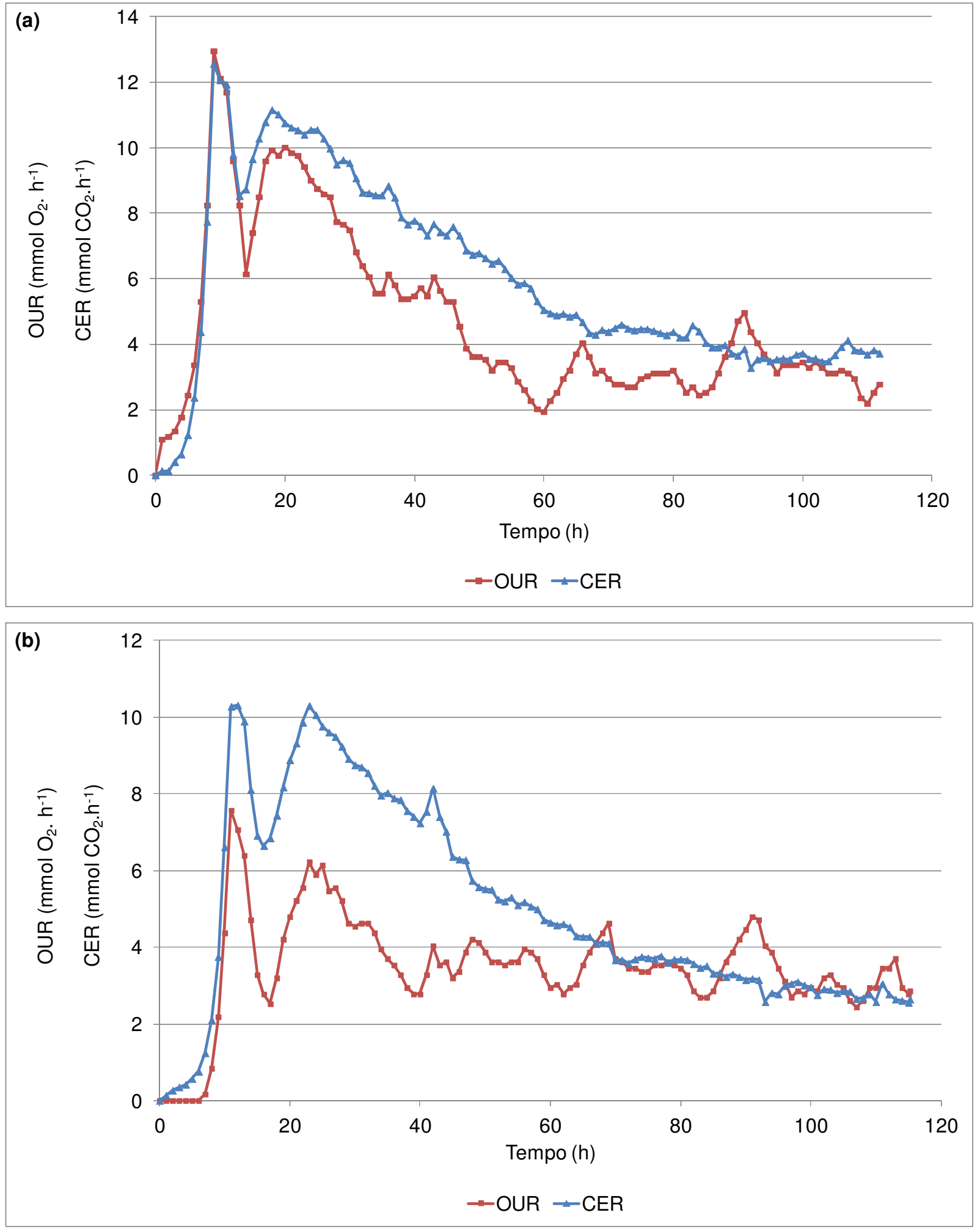

Figura 12 - Velocidades de consumo de $\mathrm{O}_{2}\left(\mathrm{OUR}, \mathrm{mmol} \mathrm{O}_{2} \cdot \mathrm{h}^{-1}\right)$ e produção de $\mathrm{CO}_{2}\left(\mathrm{CER}, \mathrm{mmol} \mathrm{CO}_{2} \cdot \mathrm{h}^{-1}\right)$ em função do tempo de cultivo de Myceliophthora sp. M77 em reator de leito fixo, meio SB (10:90) com umidade inicial de $80 \%$ para (a) Ensaio 1 e (b) Ensaio 2. 


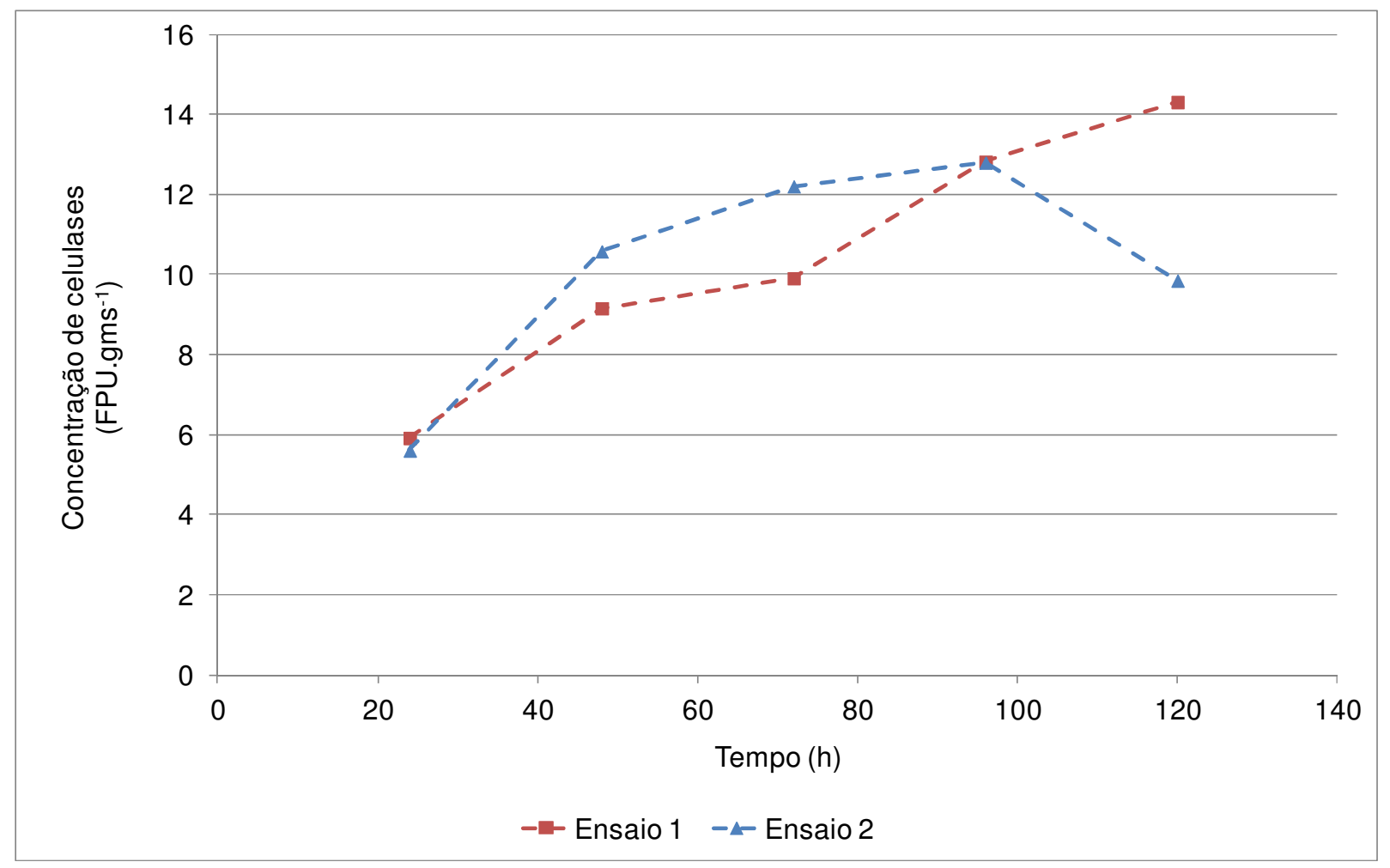

Figura 13 - Concentração de celulases $\left(\mathrm{C}_{\mathrm{FPA}}\right.$, FPU.gms ${ }^{-1}$ ) em função do tempo de cultivo de Myceliophthora sp. M77 em reator de leito fixo, meio SB (10:90) com umidade inicial de $80 \%$ para os ensaios 1 e 2.

Comparando os dois gráficos da Figura 12 observa-se que as curvas de OUR e CER para os ensaios 1 e 2 apresentam comportamento não muito diferentes, embora os valores de velocidades o sejam, principalmente para OUR nas primeiras $48 \mathrm{~h}$ de cultivo. Observa-se maior velocidade de consumo de oxigênio em torno de 10 horas de cultivo, tanto para o ensaio 1 quanto para o ensaio 2, indicando a etapa mais intensa de colonização do meio pelo microrganismo. Este crescimento inicial rápido se deve, provavelmente, ao consumo das fontes de carbono presentes no farelo de soja que são mais facilmente acessíveis ao microrganismo. Segundo Parsons et al. (2000), o farelo de soja possui cerca de $8 \%$ (base seca) de açúcares tais como sacarose $(4,5 \%)$, estaquiose $(3,2 \%)$ e rafinose $(0,3 \%)$.

Pela análise da Figura 13 tem-se que a maior velocidade de produção de celulase se apresenta nas primeiras 24 horas de cultivo. Assim, supõe-se que o segundo pico de máximo OUR observado aproximadamente às $20 \mathrm{~h}$ de cultivo (Figura 
12) está relacionado ao consumo dos polissacarídeos constituintes do meio de cultura, tais como celulose e hemicelulose, cuja degradação requer intensa liberação de enzimas celulolíticas.

Observa-se que após 24 horas de cultivo tem início uma queda na velocidade de consumo de $\mathrm{O}_{2}$ e produção de $\mathrm{CO}_{2}$, embora se verifique respiração até as $120 \mathrm{~h}$ de cultivo. Essa fase do crescimento pode ser expressa também pela análise da cinética de produção de celulases, uma vez que a curva de acúmulo de celulases apresenta velocidade decrescente a partir do primeiro dia de cultivo, mais evidenciada no ensaio 1 do que no ensaio 2. Uma projeção desse resultado para o aumento da produtividade em celulases seria então a determinação dos fatores limitantes à manutenção da velocidade de consumo de oxigênio.

Pela análise da Figura 13, tem-se que as cinética de produção de celulases nos ensaios 1 e 2 foram parecidas. Os dois ensaios apresentaram concentração de celulases de 13 FPU.gms ${ }^{-1}$ com 100 horas de cultivo. Observa-se que no período de maior velocidade de produção de celulase, ou seja, nas primeiras $48 \mathrm{~h}$ de cultivo, a produtividade média em celulase foi de 0,20 FPU.gms ${ }^{-1} \cdot \mathrm{h}^{-1}$.

Calculou-se o percentual de umidade ao longo do cultivo em estado sólido. Os resultados estão apresentados na Figura 14. 


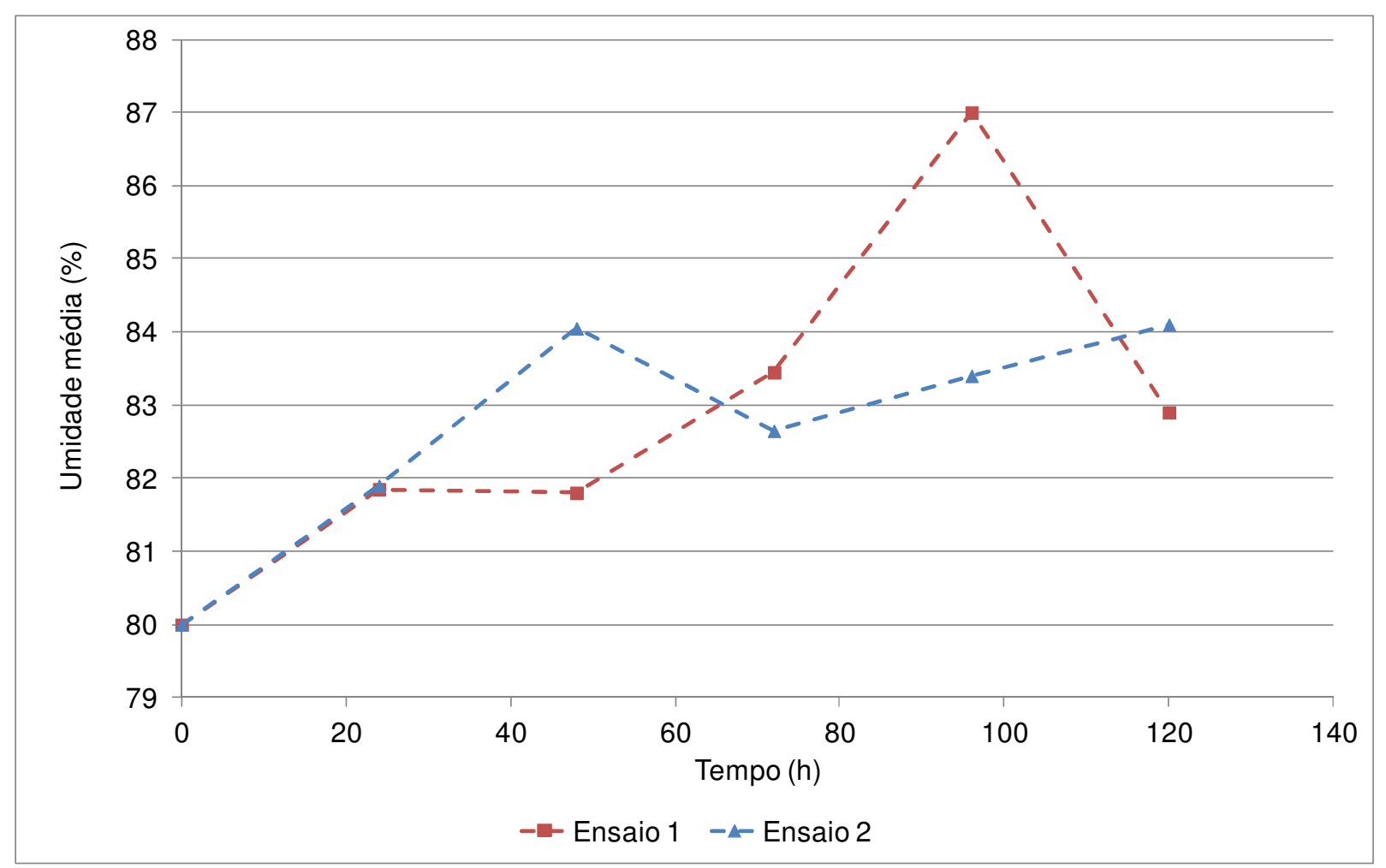

Figura 14 - Umidade média (base úmida) do meio de cultura em função do tempo de cultivo em reator de leito fixo de Myceliophthora sp. M77 em meio SB (10:90) com umidade inicial de $80 \%$, para os ensaios 1 e 2 .

Pela análise da Figura 14 tem-se que o percentual de umidade média do meio de cultura aumentou ao longo do cultivo tanto para o ensaio 1 quanto para o ensaio 2. Esse aumento pode ser explicado pelo teor de água presente na biomassa do microrganismo, uma vez que não há distinção entre a biomassa e o meio de cultura na medida da umidade.

A Figura 15 mostra o aspecto visual do meio fermentado dentro das colunas retiradas como amostras no instante inicial e após $120 \mathrm{~h}$ de cultivo. Analisando as amostras, verificou-se que após 120 h, o substrato apresentava regiões de maior concentração celular e que o crescimento do fungo se desenvolveu em volta dos grãos de farelo de soja; notou-se também que o meio fermentado estava bastante compactado. Essa compactação pode ter gerado caminhos preferenciais para passagem do ar na coluna, dificultando a transferência de oxigênio e contribuindo para limitação do crescimento celular, como observado pela análise da velocidade de consumo de oxigênio. 


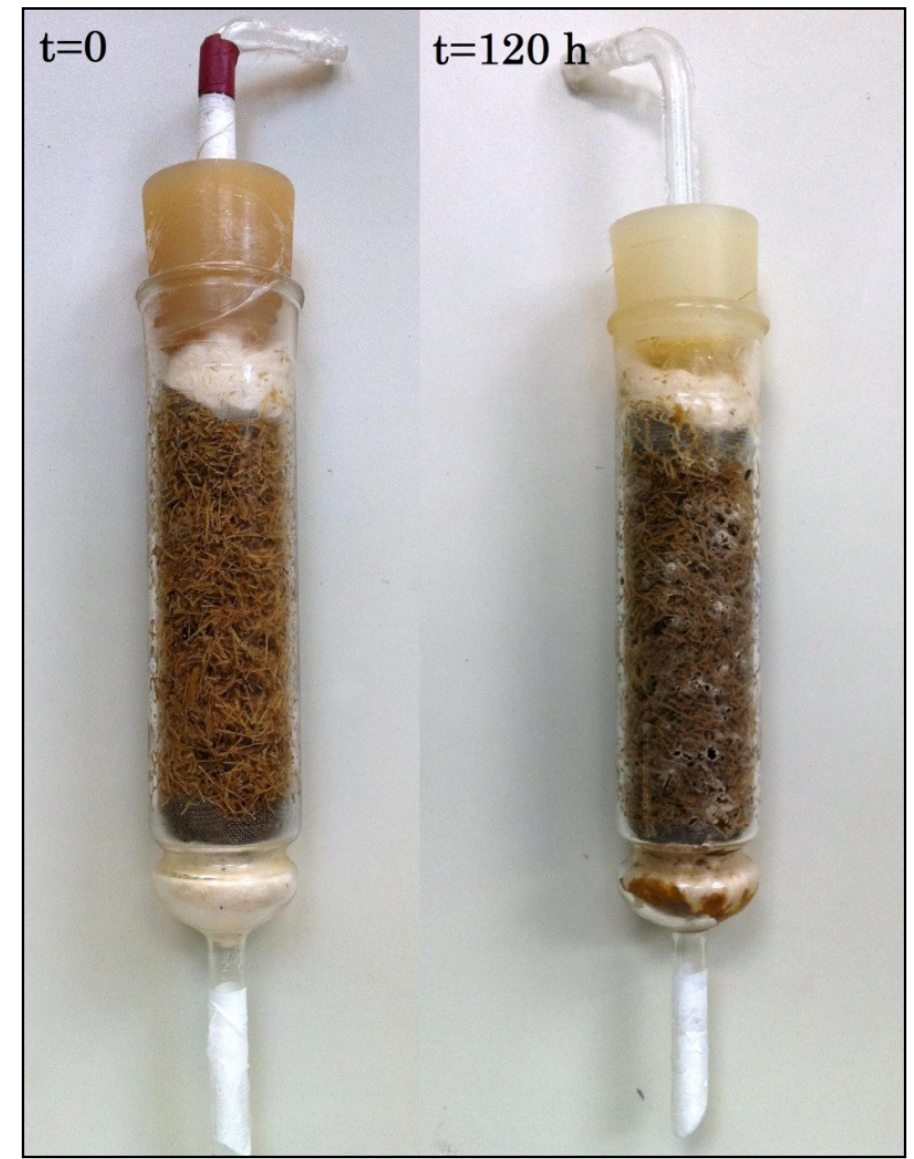

Figura 15 - Amostras dos cultivos de coluna para $t=0$ e $t=120 \mathrm{~h}$.

Os valores de OUR poderiam ser utilizados para estimar a massa celular $\left(X_{c}\right)$ ao longo do cultivo. Porém, como foram realizados apenas dois ensaios em coluna e como os resultados de OUR desses ensaios foram bastante divergentes, principalmente nas primeiras 24 horas de cultivo, decidiu-se por não fazer o cálculo de $X_{c}$.

Os cultivos em reator de leito fixo do fungo Myceliophthora sp. M77 em meio SB (10:90) com umidade inicial $80 \%$ permitiram o aumento de mais de $30 \%$ da produtividade em celulases em relação aos cultivos em frasco Erlenmeyer do mesmo fungo no mesmo meio. 


\subsection{HIDRÓLISE ENZIMÁTICA}

\subsubsection{Hidrólise enzimática de bagaço de cana-de-açúcar pré-tratado}

Um dos objetivos desta dissertação foi obter enzimas adequadas à hidrólise de bagaço de cana-de-açúcar por meio de cultivo de Myceliophthora sp. M77 e avaliar tais enzimas em reações de hidrólise. Claro está que tais reações de hidrólise poderiam ter sido todas elas conduzidas sobre bagaço tratado por um determinado processo, por exemplo, explosão a vapor. Entretanto, surgiu a oportunidade de testar as enzimas em amostras de bagaço pré-tratadas por um método novo, a saber, a radiação ionizante, que vem sendo testada no IPEN (Instituto de Pesquisas Energéticas e Nucleares).

Avaliou-se então a capacidade das enzimas produzidas por Myceliophthora sp. M77 na hidrólise do substrato bagaço de cana-de-açúcar pré-tratado por explosão a vapor ou por radiação ionizante. As enzimas para esses testes foram extraídas de CES realizado em meio constituído de farelo de trigo e bagaço de cana-de-açúcar na proporção 40:60 (massa seca) a 60\% de umidade inicial.

A Tabela 5 apresenta os resultados obtidos na hidrólise de bagaço de cana-deaçúcar in natura (A), pré-tratado por radiação ionizante em 30kGy (B), 70 kGy (C) e 150kGy (D) ou por explosão a vapor (E). Aplicaram-se enzimas comerciais (Com) e enzimas extraídas de CES (CES).

A dosagem das enzimas comerciais (Com) foi especificada em 10 FPU.gms ${ }^{-1}, 15$ U.gms ${ }^{-1}$ de $\beta$-glicosidase e 2000 U.gms $^{-1}$ de xilanase. A dosagem das enzimas de CES foi de 10 FPU.gms ${ }^{-1}$, além da suplementação com 15 U.gms ${ }^{-1}$ de $\beta$-glicosidase e 2000 U.gms ${ }^{-1}$ de xilanase.

Apresentam-se na Tabela 5 a concentração final de glicose e as conversões de celulose a glicose determinadas após $48 \mathrm{~h}$ de hidrólise, conversão essa calculada conforme descrito no item 3.2.7. A eventual liberação de xilose e celobiose nesses ensaios não pode ser determinada, devido a problemas no HPLC. 
Tabela 5 - Conversão de celulose em glicose em 48h de hidrólise de bagaço de cana: não tratado $(A)$, pré-tratados por radiação ionizante em 30kGy (B), 70 kGy (C) e 150kGy (D) e pré-tratado por explosão a vapor $(\mathrm{E})$.

\begin{tabular}{lllll}
\hline Substrato & Enzima & $\begin{array}{c}\text { Concentração de } \\
\text { Glicose } \\
\left.\text { Inicial (g. } \mathrm{L}^{-1}\right)\end{array}$ & $\begin{array}{c}\text { Concentração de } \\
\text { Glicose gerada } \\
\text { após 48h de } \\
\text { Hidrólise }\left(\mathrm{g} \cdot \mathrm{L}^{-1}\right)\end{array}$ & $\begin{array}{c}\text { Conversão de } \\
\text { Celulose em } \\
\text { Glicose (\%) }\end{array}$ \\
\hline A & Com & 0 & 0,93 & $21,0 \pm 0,5$ \\
& CES & 0,99 & 0,22 & $5,0 \pm 1,3$ \\
\hline B & Com & 0 & 0,96 & $21,9 \pm 0,1$ \\
& CES & 0,99 & 0,22 & $7,2 \pm 1,9$ \\
\hline C & Com & 0 & 0,96 & $21,8 \pm 0,3$ \\
& CES & 0,99 & 0,30 & $6,8 \pm 0,1$ \\
\hline D & Com & 0 & 0,93 & $21,04 \pm 0,07$ \\
& CES & 0,99 & 0,21 & $4,7 \pm 1,2$ \\
\hline E & Com & 0 & 1,47 & $33,3 \pm 2,9$ \\
& CES & 0,99 & 0,27 & $6,0 \pm 0,9$ \\
\hline
\end{tabular}

De acordo com a Tabela 5, para a hidrólise com enzimas comerciais (Com) o melhor resultado de conversão de celulose a glicose foi obtido na hidrólise do bagaço de cana tratado por explosão a vapor $(33,3 \pm 2,9 \%)$. Todavia, mesmo para esse resultado, pode-se dizer que a conversão foi muito modesta, mais ainda ao se considerar que houve $21 \%$ de conversão, com o bagaço in natura.

De modo geral, as hidrólises realizadas com as enzimas extraídas do CES alcançaram conversões reduzidíssimas, da ordem de 5\%, o que faz supor que a composição qualitativa das enzimas no extrato de Myceliophthora sp. M77 é deficiente. Sabe-se que o complexo denominado celulases é composto por mais de vinte enzimas que agem sinergicamente sobre o substrato hidrolisando o material lignocelulósico. As enzimas comerciais são uma mistura de enzimas obtidas de diferentes microrganismos com a finalidade de formar um coquetel de enzimas com altas concentrações das principais frações enzimáticas que compõem as celulases. 
Já os resultados das hidrólises realizadas com as amostras de bagaço prétratado por radiação ionizante, fazem supor que tal pré-tratamento é inócuo, uma vez que as conversões de celulose a glicose, seja para as enzimas comerciais seja para as enzimas do CES, são equivalentes entre si e são equivalentes quando comparadas ao bagaço in natura.

Além dos dados de conversão de celulose a glicose, a Tabela 5 apresenta as concentrações de glicose no início da hidrólise. A maior concentração nos ensaios com enzimas produzidas por CES deve-se ao fato do extrato enzimático utilizado nesses ensaios conter aproximadamente $1 \mathrm{~g} \cdot \mathrm{L}^{-1}$ de glicose. Essa glicose provavelmente foi produzida durante os cultivos em estado sólido e, portanto, retirada do meio sólido juntamente com as enzimas no processo de extração.

De acordo com Phillippidis et al. (1992), numa concentração de $3 \mathrm{~g} \cdot \mathrm{L}^{-1}$ de glicose, verificou-se inibição tal que apenas $25 \%$ da atividade inicial de $\beta$-glicosidase (25 U. $\mathrm{mL}^{-1}$ ) foi preservada num ensaio de hidrólise contendo $10 \mathrm{~g} \cdot \mathrm{L}^{-1}$ de celobiose e 60 g. $\mathrm{L}^{-1}$ de celulose. Moretti (2010) observou-se redução de $40 \%$ da atividade da enzima $\beta$ glicosidase de Myceliophthora sp. M77 na presença de 1,44 g. $\mathrm{L}^{-1}$ de glicose, porém não foi observada inibição por glicose da enzima endoglicanase. Tendo em vista esses dados de Phillippidis et al. (1992) e Moretti (2010), a inibição exercida por $1 \mathrm{~g} . \mathrm{L}^{-1}$ de glicose sobre a $\beta$-glicosidase nos ensaios ora discutidos foi provavelmente importante, dado que a concentração de bagaço era de $0,01 \mathrm{~g} \cdot \mathrm{L}^{-1}$, o que equivale a aproximadamente $0,0049 \mathrm{~g} \cdot \mathrm{L}^{-1}$ de celulose (para o bagaço tratado por explosão a vapor), sendo mais uma justificativa para os baixos valores de conversão na hidrólise com enzimas produzidas por CES. O mesmo motivo, ou seja, a inibição por glicose, pode ter causado a quase cessação das hidrólises com enzimas comerciais às $24 \mathrm{~h}$ de reação quando a concentração de glicose atingiu valores maiores que $1 \mathrm{~g} \cdot \mathrm{L}^{-1}$. As conversões de celulose a glicose reportadas para 48h de hidrólise, na Tabela 5, são praticamente as mesmas verificadas às $24 \mathrm{~h}$ (Dados não mostrados).

Os resultados das hidrólises apresentados na Tabela 5 são inferiores quando comparados aos resultados da literatura. Kovacs et al. (2009) relatam conversão de celulose a glicose de 55\% em 96 h de hidrólise de bagaço de cana-de-açúcar tratado por explosão a vapor, com enzimas produzidas 'in house' sendo que a carga enzimática 
utilizada foi de $3 \mathrm{FPU} / \mathrm{g}$ de sólido insolúvel em água. Zhao et al. (2009) relatam uma conversão de 56,2 \% após 120h de hidrólise com 15 FPU/g de sólido de bagaço prétratado com $\mathrm{NaOH}$. Vale ressaltar que os dois autores relatam que houve alta deslignificação da biomassa após o pré-tratamento, contribuindo para uma maior conversão de celulose.

\subsubsection{Hidrólise enzimática a diferentes temperaturas}

Com a finalidade de verificar qual a melhor temperatura para a ação das enzimas produzidas pelo fungo Myceliophthora sp. M77 foram realizados ensaios de hidrólise nas temperaturas de $50^{\circ} \mathrm{C}, 60^{\circ} \mathrm{C}$ e $70^{\circ} \mathrm{C}$, tendo como substrato bagaço de cana-deaçúcar pré-tratado por explosão à vapor. A possibilidade de condução da reação de hidrólise a temperaturas superiores a $50^{\circ} \mathrm{C}$ é atraente tendo em vista maiores velocidades de hidrólise, menor viscosidade do meio a qual facilita operações de homogeneização, difusividade das enzimas, maiores concentrações de substratos e produtos, e menor probabilidade de agregação de contaminantes microbianos nesta etapa do processo (MORETTI, 2010).

O extrato enzimático aplicado às reações de hidrólise a diferentes temperaturas foi obtido em CES em meio composto por farelo de soja e bagaço de cana, SB (10:90), com umidade inicial de $60 \%$. A dosagem das enzimas de CES foi de 10 FPU.gms ${ }^{-1}$. 


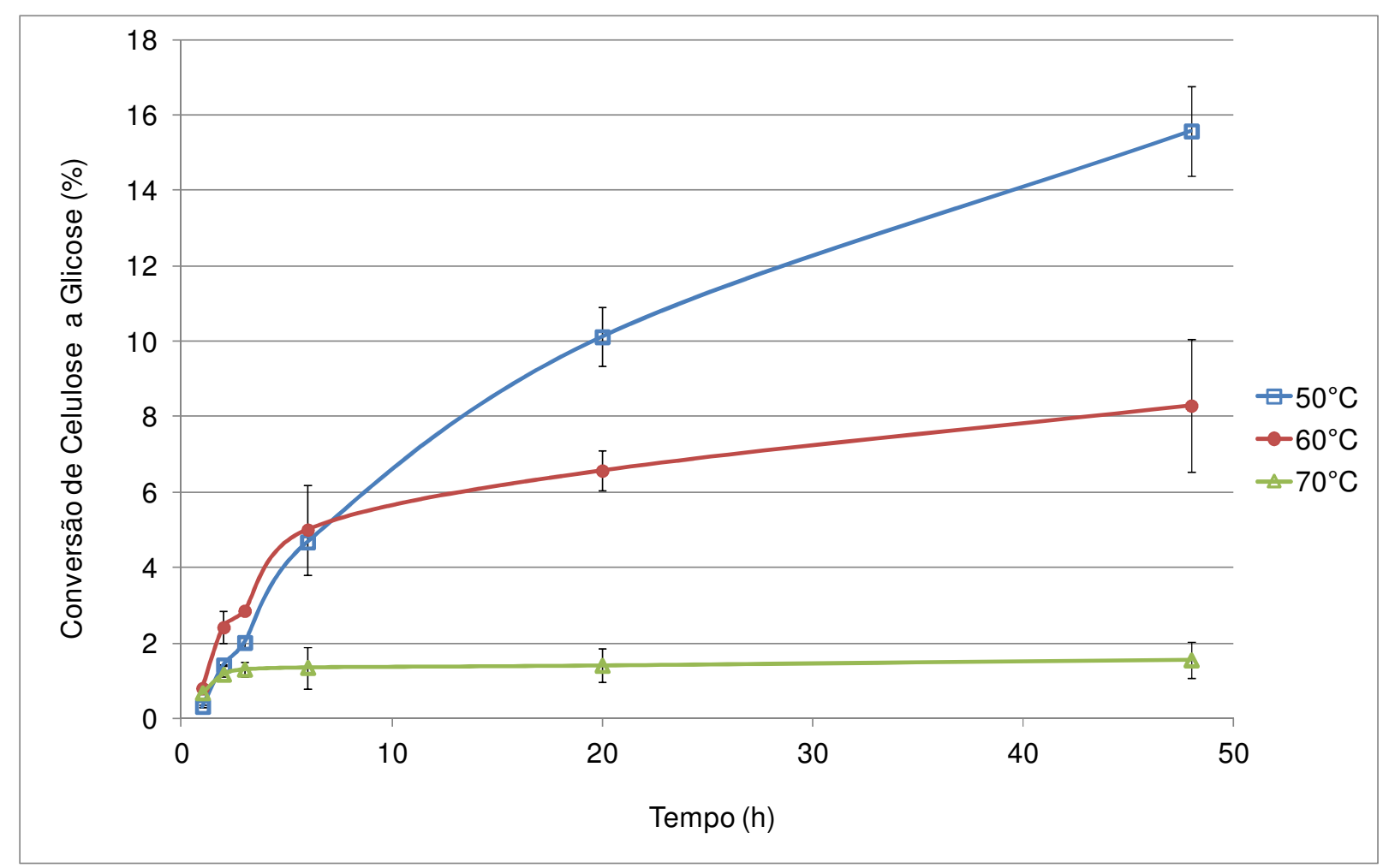

Figura 16 - Conversão de celulose a glicose (\%) na hidrólise de bagaço pré-tratado por explosão a vapor, com enzimas produzidas por CES, sem suplementação de xilanase e $\beta$-glicosidase (concentração de sólidos $1 \%$ e adição de 10 FPU/gms bagaço).

Pela análise da Figura 16 , a hidrólise a $50^{\circ} \mathrm{C}$ resultou o maior valor de conversão da celulose a glicose, que foi de 16\% em 48h de reação. Esse valor de conversão é 2,7 vezes superior em relação ao valor de $6 \%$ reportado na Tabela 5 , para o mesmo bagaço pré-tratado por explosão a vapor e para a mesma atividade em papel de filtro no extrato enzimático (10 FPU.gms ${ }^{-1}$ ). A diferença entre os dois ensaios de hidrólise foi que o meio de cultivo da Myceliophthora sp. M77 para produção do extrato no presente caso foi constituído por bagaço de soja a 10\% (massa seca) e no caso dos dados da Tabela 5 foi constituído de farelo de trigo a 40\% (massa seca), além de bagaço de cana. Além disso, o extrato aplicado no ensaio de hidrólise ora apresentado, não foi acrescido de $\beta$-glicosidase e xilanase, ao contrário do ensaio da Tabela 5 , levando a supor, portanto, que o conjunto de moléculas produzidas em meio com bagaço de soja apresenta atuação mais eficiente na hidrólise enzimática do bagaço de cana quando comparado com o extrato produzido em meio com farelo de trigo. Outra vantagem do extrato produzido por farelo de soja foi que este apresentou uma menor concentração 
final de glicose, $0,13 \mathrm{~g} \cdot \mathrm{L}^{-1}$, diminuindo possivelmente o efeito inibitório desse açúcar sobre as enzimas no início do ensaio de hidrólise. Com base nesses resultados de hidrólise pode-se supor que a composição química e enzimática dos dois extratos é diferente, e a diferença não pode ser evidenciada na medida de atividade enzimática global medida com papel de filtro.

As curvas de conversão de celulose a glicose apresentadas na Figura 16, mostram que houve redução de velocidade para as três temperaturas, sobretudo, para $60^{\circ} \mathrm{C}$ e $70^{\circ} \mathrm{C}$, após 6 horas e 2 horas de reação, respectivamente. Isto se deve, provavelmente, à desnaturação das enzimas em função das temperaturas aplicadas.

A atividade residual de Filter Paper foi medida durante os ensaios de hidrólise a $50^{\circ} \mathrm{C}$ e $60^{\circ} \mathrm{C}$, como verificado na Figura 17 . Não foi possível realizar essas medidas para a hidrólise a $70^{\circ} \mathrm{C}$.

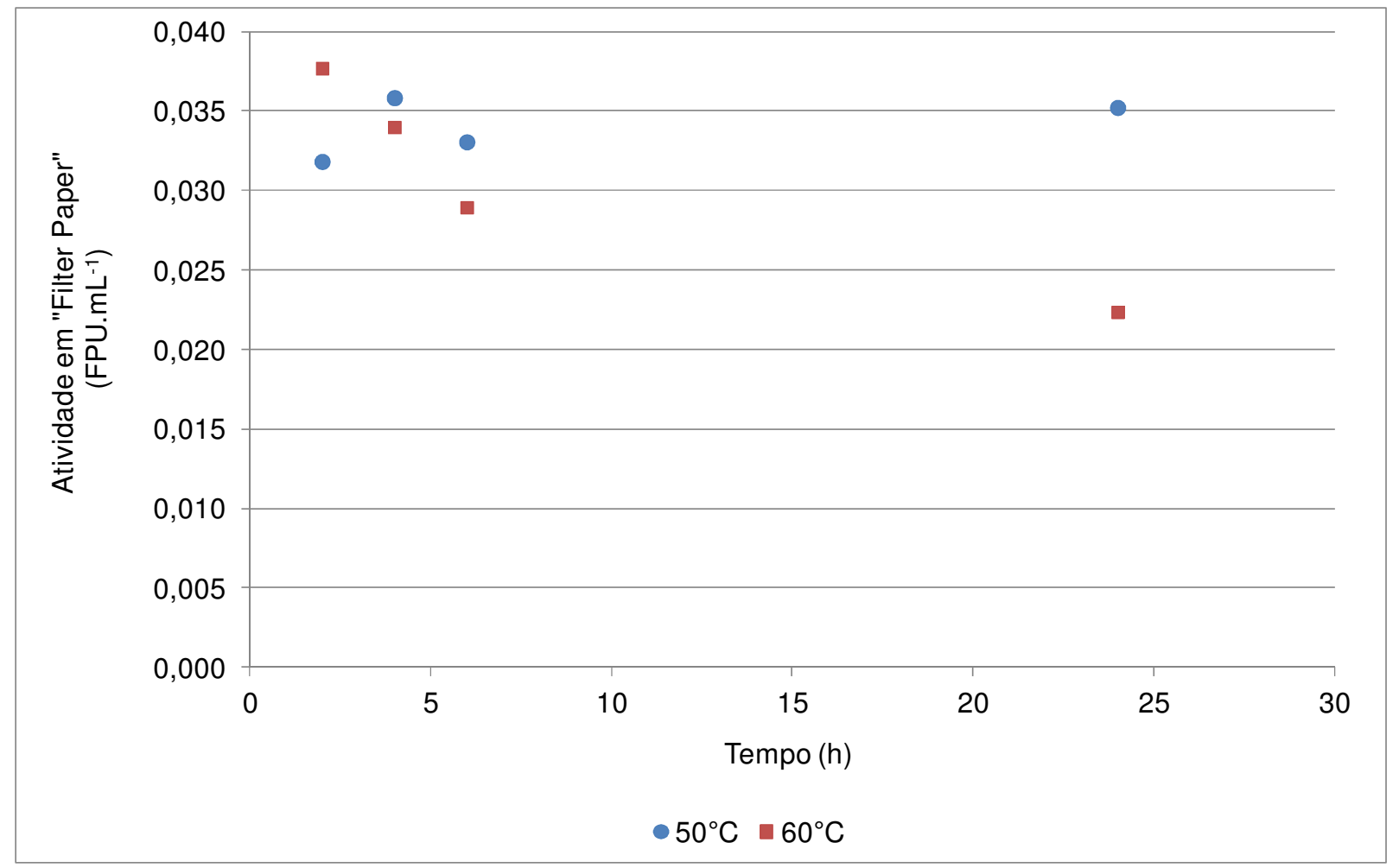

Figura 17 - Atividade em 'Filter Paper' durante os ensaios a $50^{\circ} \mathrm{C}$ e $60^{\circ} \mathrm{C}$ de hidrólise de bagaço de canade-açúcar pré tratado por explosão a vapor com extrato enzimático produzido por CES de Myceliophthora sp. M77 em meio SB (10:90) com 60\% de umidade inicial. 
Os resultados da Figura 17 mostram claramente que houve redução da atividade enzimática de FP durante as primeiras $24 \mathrm{~h}$ do ensaio de hidrólise a $60^{\circ} \mathrm{C}$ enquanto que para os ensaios a $50^{\circ} \mathrm{C}$ essa redução não foi observada.

As enzimas xilanase e endoglicanase do microrganismo Myceliophthora sp. M77 foram consideradas termofílicas pelo grupo do IBILCE/ UNESP/ Campus de São José do Rio Preto/Depto de Biologia, onde a M77 foi isolada, por terem apresentado temperatura ótima de $70^{\circ} \mathrm{C}$. Porém, há que se considerar que tal conclusão foi baseada em ensaio com 10 minutos de duração (MORETTI, 2010). Nos ensaios de hidrólise apresentados nesta dissertação com duração de 48h, verificou-se significativa redução da velocidade para os ensaios a $60^{\circ} \mathrm{C}$ e $70^{\circ} \mathrm{C}$.

Além da desnaturação térmica, concorre para a desaceleração das reações de hidrólise a redução da massa de celulose facilmente acessível às enzimas e o acúmulo de inibidores que são os produtos da reação (BALAT et al., 2008).

\subsubsection{Hidrólise com e sem extração de enzimas de CES}

Tendo em vista que a extração das enzimas de CES pode ser incompleta, isto é, parte da atividade enzimática pode permanecer no meio de cultura sólido, e ainda, que nem todas as frações enzimáticas produzidas podem ter o mesmo rendimento na extração (CASTILHO et al., 1999; REZAEl et al., 2011), pode-se supor que nem todo o potencial das enzimas produzidas em CES possa ser aproveitado na hidrólise de bagaço de cana-de-açúcar quando da utilização de um extrato de enzimas. Assim, foi investigada a hidrólise com enzimas aderidas ao meio de cultura.

Obtiveram-se as enzimas para os ensaios de hidrólise por CES de Myceliophthora sp. M77 em meio SB (10:90) com umidade inicial de 80\%, a temperatura de $45^{\circ} \mathrm{C}$ por cinco dias.

Como substrato da hidrólise utilizou-se celulose cristalina e bagaço de cana-deaçúcar pré-tratado por explosão a vapor. Aplicou-se dosagem de atividade de 'Filter 
Paper' de 10 FPU.(gms de celulose $\left.{ }^{-1}\right)$. Foram realizados ensaios com suplementação de $\beta$-glicosidase a 15 U.(gms celulose ${ }^{-1}$ ) e ensaios sem suplementação dessa enzima.

Os resultados de conversão de celulose dos ensaios de hidrólise, com enzimas aderidas ao meio de cultura (HAd) e com enzimas extraídas do meio de cultura (HEx), dos substratos celulose cristalina e bagaço de cana-e-açúcar pré-tratado por explosão à vapor são apresentados nas Figuras 18 e 19.

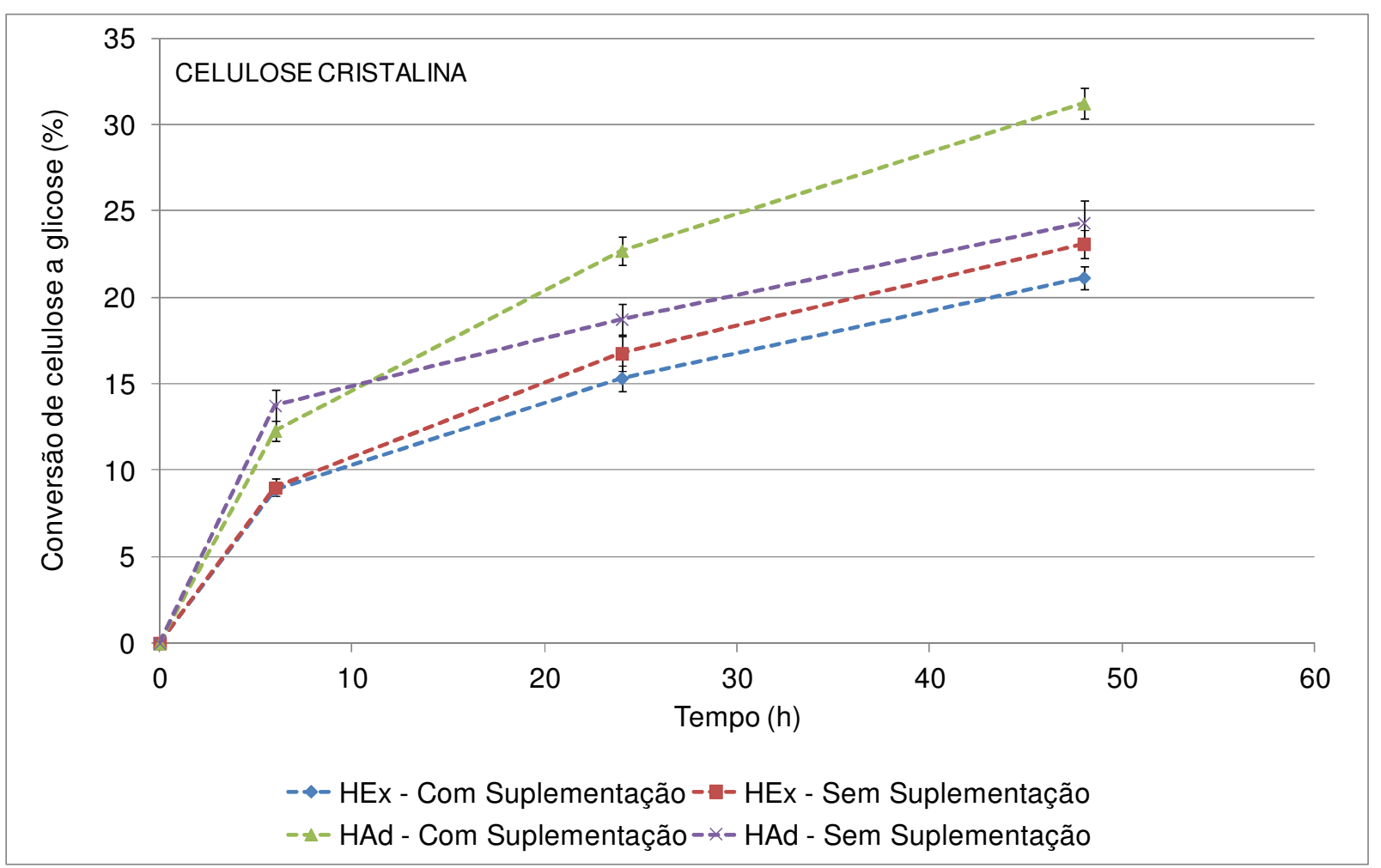

Figura 18 - Conversão de celulose a glicose em função do tempo reacional para reação de HEx e HAd de celulose cristalina, com e sem suplementação de $\beta$-glicosidase . 


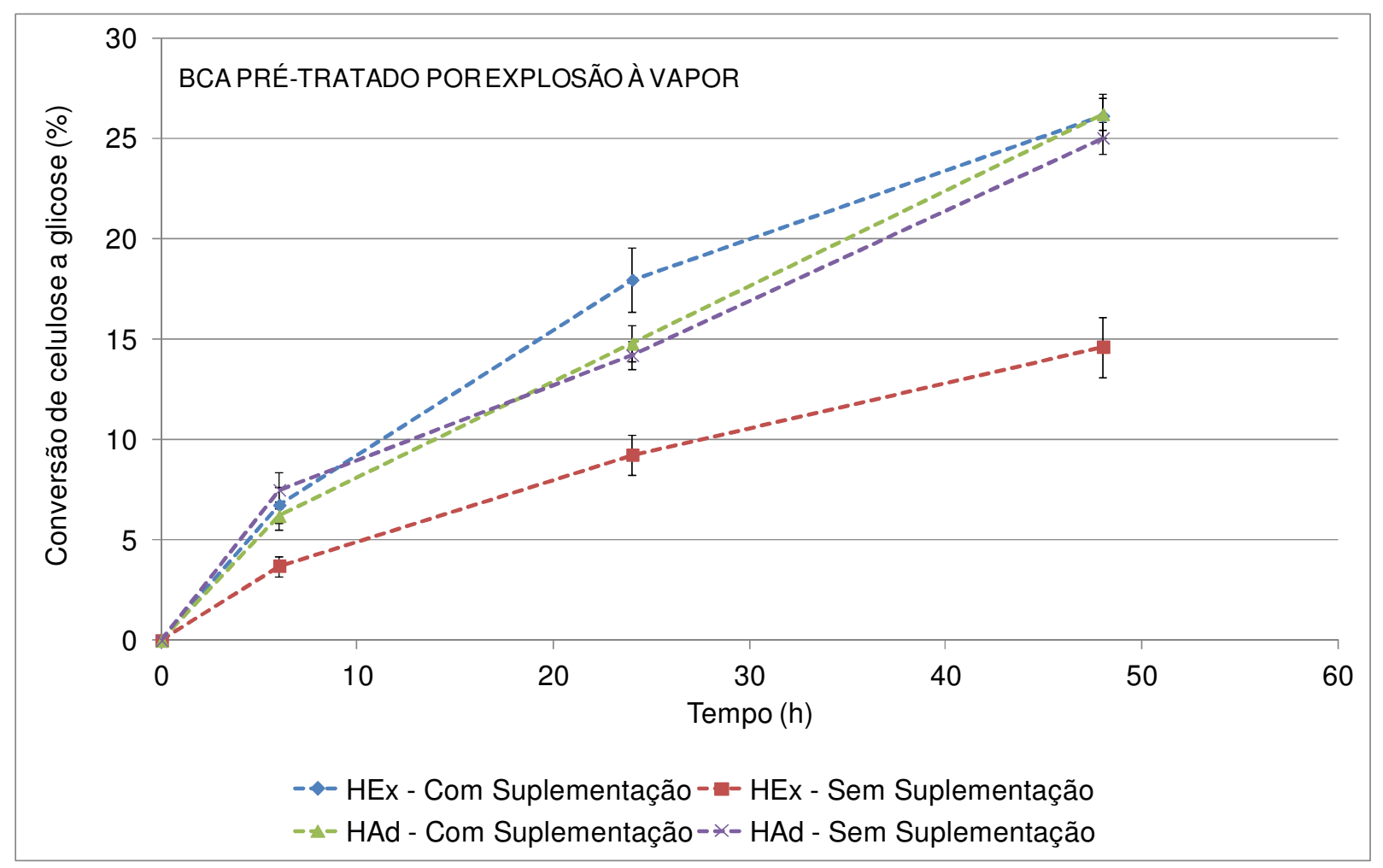

Figura 19 - Conversão de celulose a glicose em função do tempo reacional para reação de HEx e HAd do substrato bagaço de cana-de-açúcar pré-tratado por explosão à vapor, com e sem suplementação de $\beta$ glicosidase.

Pela análise da Figura 18, observa-se que após 48h, a conversão de celulose a glicose na hidrólise da celulose cristalina com suplementação de $\beta$-glicosidase é 55\% maior para o ensaio de HAd do que para o ensaio de HEx. Observou-se que a suplementação de $\beta$-glicosidase nos ensaios de HAd de celulose cristalina aumentou em 33\% a conversão de celulose em glicose em relação ao ensaio de HAd sem suplementação. Esse comportamento não foi verificado nos ensaios de HEx para o mesmo substrato. Pelo contrário, a conversão em $48 \mathrm{~h}$ para o ensaio de HEx sem suplementação foi ligeiramente maior do que para o ensaio de HEx com suplementação.

Observa-se na Figura 18, que até 6 h da HAd, a conversão para o ensaio com suplementação de $\beta$-glicosidase é a mesma encontrada para o ensaio sem suplementação e que a partir desse momento, a velocidade de conversão para o ensaio sem suplementação decresce em relação ao ensaio suplementado. Isso se deve, provavelmente, ao aumento gradual da concentração de celobiose ao longo da reação 
de hidrólise, sendo que a deficiência em $\beta$-glicosidase somente se fez sentir à medida que a celobiose se acumulou no meio reacional. Além disso, a celobiose pode inibir a ação das endoglicanases, resultando numa diminuição do rendimento do processo de sacarificação.

Para a hidrólise do bagaço de cana pré-tratado por explosão a vapor (Figura 19) foi observado que o ensaio de HEx com suplementação de $\beta$-glicosidase tem uma maior velocidade de conversão nas primeiras $24 \mathrm{~h}$ de reação em relação ao ensaio de HAd com suplementação. Porém, ao final das 48h de reação, para ambos os ensaios verifica-se a mesma conversão de celulose a glicose, em torno de $25 \%$.

Observou-se que a suplementação com $\beta$-glicosidase não influenciou os resultados de conversão nos ensaios de HAd de bagaço pré-tratado por explosão à vapor. Já para os ensaios de HEx, a conversão de celulose a glicose do ensaio com suplementação foi $67 \%$ maior do que para o ensaio sem suplementação.

Juntamente aos ensaios de hidrólise, foi realizado um ensaio Referência nas mesmas condições dos ensaios de HAd porém sem a adição do substrato. Observou-se que após $48 \mathrm{~h}$ em shaker a $50^{\circ} \mathrm{C}$, a concentração de glicose foi muito baixa a ponto de não ser detectada pelo HPLC. Esse resultado indica que o material lignocelulósico do meio de cultivo não influenciou os resultados de hidrólise com enzimas aderidas ao meio. Essa era uma preocupação quanto ao emprego desse método, pois, o próprio meio de cultura que contem as enzimas é um material lignocelulósico e, portanto, poderia ser hidrolisado juntamente com a celulose cristalina ou bagaço de cana-deaçúcar pré-tratado, afetando o resultado de conversão de celulose a glicose.

Após $48 \mathrm{~h}$ de reação, a atividade residual de Filter Paper foi medida para os ensaios de HAd e HEx, com celulose cristalina, com e sem suplementação de $\beta$ glicosidase. Também foi analisada a atividade residual no ensaio Referência. Os resultados estão apresentados na Tabela 6. 
Tabela 6 - Atividade de Filter Paper após 48h de reação de hidrólise de celulose cristalina

\begin{tabular}{lc}
\hline \multicolumn{1}{c}{ Ensaio } & $\mathrm{C}_{\mathrm{FPA}}\left(\mathrm{FPU} \cdot \mathrm{mL}^{-1}\right)$ \\
\hline HAd Com suplementação & $0,097 \pm 0,008$ \\
HAd Sem suplementação & $0,046 \pm 0,009$ \\
HEx Com suplementação & $0,095 \pm 0,009$ \\
HEx Sem suplementação & $0,06 \pm 0,01$ \\
Referência & $0,04 \pm 0,01$ \\
\hline
\end{tabular}

Observa-se que as atividades de Filter Paper residuais para os ensaios de HAd e HEx sem suplementação são iguais, mesmo resultado encontrado quando comparadas as atividades para os ensaios com suplementação. Estes resultados mostram que embora tenham sido aplicadas as mesmas atividades enzimáticas, em termos de atividade de Filter Paper (FPU/g de celulose), outras frações enzimáticas foram determinantes para obtenção de resultados diferentes de conversões nas hidrólises.

Observa-se que para o ensaio Referência, em que não há adição de substrato para a hidrólise, a atividade enzimática de Filter Paper é semelhante a dos ensaios de hidrólise sem suplementação. Esse resultado indica que se houve redução da atividade enzimática nos ensaios de hidrólise após $48 \mathrm{~h}$ de reação a $50^{\circ} \mathrm{C}$, essa redução foi a mesma comparada àquela apresentada pelo ensaio Referência, em que não ocorre hidrólise.

Pela análise da atividade residual nos ensaios de hidrólise, pode-se supor que ambos meios reacionais (HAd e HEx) apresentavam a mesma atividade global de celulases ao final das $48 \mathrm{~h}$ de reação. Porém, a composição quantitativa e qualitativa das frações enzimáticas que compõem o complexo celulase pode ser diferente. Assim, para obtenção de resultados mais conclusivos quanto ao desempenho de ensaios de hidrólise com enzimas produzidas por CES aderidas ao meio de cultura ou extraídas do meio de cultura seria importante medir separadamente a atividade de endoglicanase, celobio-hidrolase e $\beta$-glicosidase.

De modo geral, os resultados observados tanto pela hidrólise de celulose cristalina quanto para a hidrólise do bagaço de cana-de-açúcar pré-tratado mostraram que é possível utilizar as enzimas produzidas por CES do fungo Myceliophthora sp. 
M77 ainda aderidas ao meio. Assim, pode-se concluir que é viável investir no desenvolvimento desta forma de realizar a hidrólise, eliminando a etapa de extração e, portanto, diminuindo os custos totais de produção da enzima. 


\section{CONCLUSÕES}

\subsection{PRODUÇÃO DE CELULASES POR CULTIVO EM ESTADO SÓLIDO (CES)}

\subsubsection{Avaliação de meios de cultura na produção de celulases por Myceliophthora sp. M77 em CES}

- Cultivos em meios sólidos compostos por farelo de trigo e bagaço de canade-açúcar, e farelo de soja e bagaço de cana-de-açúcar, permitiram concluir que o farelo de soja é melhor substrato do que farelo de trigo tanto para obtenção de maior concentração de celulases quanto para produtividade em celulase. No quinto dia de cultivo, $\mathrm{C}_{\mathrm{FPA}}$ em meio SB (10:90) foi quase três vezes maior do que em meio TB (10:90), ambos com umidade inicial de 60\%.

- O aumento da umidade inicial de $60 \%$ para $80 \%$ no cultivo de Myceliophthora sp. M77 em meio SB (10:90) resultou $\mathrm{C}_{\mathrm{FPA}}$ de 10,6 $\pm 0,8 \mathrm{U.gms}^{-1}$, valor ao qual corresponde aumento de $68 \%$ na produção em cinco dias de cultivo.

- A produtividade em celulases alcançou valor máximo no segundo dia de cultivo para todos os meios de cultura empregados.

- A partir de 48h de cultivo, verificou-se decréscimo da produtividade de celulases para praticamente todos os meios de cultura empregados.

\subsubsection{Cultivos de Myceliophthora sp. M77 em coluna de Raimbault}

- O cultivo de Myceliophthora sp. M77 em meio composto por $10 \%$ de farelo de soja e $90 \%$ de bagaço de cana-de-açúcar com umidade inicial de $80 \%$, realizado em reator de leito fixo com aeração forçada na vazão de 0,125 
$\mathrm{mL} \cdot \mathrm{min}^{-1} . \mathrm{gms}^{-1}$ resultou aumento de $33 \%$ da produtividade em celulase no instante 48 h, em relação ao cultivo em frasco Erlenmeyer.

\subsection{HIDRÓLISE ENZIMÁTICA}

\subsubsection{Hidrólise enzimática de bagaço de cana-de-açúcar pré-tratado}

- O extrato enzimático obtido por CES de Myceliophthora sp. M77 em meio TB (40:60) foi ineficiente na hidrólise de bagaço de cana-de-açúcar submetido a diferentes pré-tratamentos. Supõe-se que a presença de glicose em concentrações superiores a $1 \mathrm{~g} / \mathrm{L}$ no extrato enzimático possa ter inibido a ação da enzima $\beta$-glicosidase.

- O pré-tratamento do bagaço de cana-de-açúcar por radiação ionizante em doses de 30, 70 e 150 kGy não foi suficiente para aumentar o rendimento das hidrólises de bagaço de cana-de-açúcar in natura.

\subsubsection{Hidrólise enzimática a diferentes temperaturas}

- A hidrólise de bagaço de cana de açúcar pré-tratado por explosão à vapor com enzimas produzidas por CES de Myceliophthora sp. M77 em meio SB (10:90) a temperatura de $50^{\circ} \mathrm{C}, 60^{\circ} \mathrm{C}$ e $70^{\circ} \mathrm{C}$ apresentaram conversão de celulose a glicose de $16 \%, 8 \%$ e $1,5 \%$, respectivamente.

- A hidrólise de bagaço de cana de açúcar pré-tratado por explosão à vapor com extrato produzido em meio SB (10:90), a $50^{\circ} \mathrm{C}$, com aplicação de 10 FPU.gms ${ }^{-1}$, apresentou conversão de celulose a glicose $50 \%$ maior do que a hidrólise nas mesmas condições porém com enzimas produzidas em meio 
TB(40:60). Assim, não é possível afirmar que dois extratos contendo a mesma atividade em celulases, medida em FP, apresentem mesmo desempenho na hidrólise, se os extratos foram obtidos em diferentes meios de cultivo.

\subsubsection{Hidrólise com e sem extração de enzimas produzidas por CES}

- O emprego de enzimas produzidas por CES aderidas ao meio de cultura se mostrou eficiente, uma vez que os resultados de conversão de celulose a glicose foram próximos ou até mesmo maiores do que aqueles alcançados para as mesmas hidrólises com enzimas previamente extraídas do meio de cultura sólido.

- As hidrólises de celulose cristalina com enzimas não extraídas do meio de cultura e com enzimas extraídas apresentaram conversões de celulose à glicose de $31 \%$ e $26 \%$, respectivamente, após $48 \mathrm{~h}$ de ensaio com suplementação inicial de $\beta$-glicosidase. Os ensaios sem suplementação apresentaram a mesma conversão final, aproximadamente $24 \%$.

- As hidrólises de bagaço de cana-de-açúcar pré-tratado por explosão a vapor, suplementado de $\beta$-glicosidase, com enzimas não extraídas do meio de cultura e com enzimas extraídas apresentaram a mesma conversão final de $26 \%$. Já para os ensaios sem suplementação, a conversão de celulose a glicose das hidrólises com enzimas aderidas ao meio de cultura foi $85 \%$ maior do que para a hidrólise com enzimas extraídas do meio de cultura. 


\section{CONTINUIDADE DO TRABALHO}

Com base nos resultados obtidos neste trabalho, apresentam-se algumas sugestões para a continuidade do mesmo, a saber:

- Avaliar o aumento da umidade inicial nos CES de outros substratos, uma vez que se verificou aumento da concentração de celulases quando a umidade inicial passou de $60 \%$ para $80 \%$ nos CES de Myceliophthora sp. M77 em meio SB (10:90), e esse aumento da umidade não foi testado para os outros meios de cultura analisados.

- Analisar a influência da aeração nos cultivos em estado sólido, uma vez que o ensaio em reator de leito fixo com aeração forçada apresentou maior produtividade em relação ao ensaio em frasco Erlenmeyer.

- Avaliar a composição do extrato enzimático produzido por CES quanto às diferentes frações de enzimas que participam da hidrólise da celulose, tais como, $\beta$-glicosidade, endoglicanase e celobio-hidrolase.

- Explorar a hidrólise enzimática com enzimas ainda aderidas no meio de cultura sólido, uma vez que esse resultado foi bastante positivo e seria um fator importante para a diminuição do custo do processo de hidrólise enzimática de materiais lignocelulósicos e para a obtenção de meios com concentrações de glicose que viabilizam a produção de etanol, sobretudo, quanto a diminuição dos custos de destilação. 


\section{REFERÊNCIAS BIBLIOGRÁFICAS}

AHMED, S. A. Optimization of production and extraction parameters of Bacillus megaterium levansucrase using solid-state fermentation. J. Appl. Sci. Res., v. 4, n. 10, p. 1199-1204, 2008.

BADHAN, A. K.; CHADHA, B. S.; KAUR, J.; SAINI, H. S.; BHAT, K. M. Production of multiple xylanolytic and cellulolytic enzymes by thermophilic fungus Myceliophthora sp. IMI 387099. Bioresour. Technol., v. 98, p. 504-510, 2007.

BALAT, M.; BALAT, H.; OZ, C. Progress in bioethanol processing. Prog. Energy Combust. Sci., v. 34, p. 551-573, 2008.

BALLESTEROS, I.; NEGRO, M. J.; OLIVA, J. M.; CABANAS, A.; MANZANARES, P.; BALLESTEROS, M. Ethanol production from steam explosion pretreated wheat straw. Appl. Biochem. Biotechnol., v. 70-72, p. 3-15, 2006.

BEZERRA, R.; DIAS, A. Enzymatic Kinetic of Cellulose Hydrolysis - Inhibition by Ethanol and Cellobiose. Appl. Biochem. Biotechnol., v. 126, p. 49-59, 2005.

BHAT, K. M.; BHAT, S. Cellulose degrading enzymes and their potential industrial applications. Biotechnol. Adv., v. 15 (3-4), p. 583-620, 1997.

BHAT, K. M.; GAIKWAD, J. S.; MAHESHWARI, R. Purification and characterization of an extracellular $\beta$-glucosidase from the thermophilic fungus Sporotrichum thermophile and its influence on cellulase activity. J. Gen. Microbiol., v. 139, p. 2825-2832, 1993.

BHAT, K. M.; MAHESHWARI, R. Sporotrichum thermophile: Growth, cellulose degradation and cellulase activity. Appl. Environ. Microbiol., v. 53, p. 21752182, 1987.

CAMASSOLA, M.; DILLON, A. J. P. Cellulases and xylanases production by Penicillium echinulatum grown on sugar cane bagasse in solid-state fermentation. Appl. Biochem. Biotechnol., v. 162, p. 1889-1900, 2010. 
CAMASSOLA, M.; DILLON, A. J. P. Production of cellulases and hemicellulases by Penicillium equinulatum grown on pretreated sugar cane bagasse and wheat bran in solid-state fermentation. J. Appl. Microbiol., v. 103, n. 6, p. 2196-2204, 2007.

CANNEL, E.; MOO YOUNG, M. Solid-state fermentation systems. Process. Biochem., v. 4 , p. 2-7, 1980.

CASTILHO, L. R.; ALVES, T. L. M.; MEDRONHO, R. A. Recovery of pectolytic enzymes produced by solid state culture of Aspergillus niger. Process Biochem., v. 34, p. 181-186, 1999.

CASTILHO, L. R.; MEDRONHO, R. A.; ALVES, T. L. M. Production and extraction of pectinases obtained by solid state fermentation of agroindustrial residues with Aspergillus niger. Bioresour. Technol., v. 71, p. 45-50, 2000.

CASTRO, A. M. Produção, propriedades e aplicação de celulases na hidrólise de resíduos agroindustriais. Quim. Nova, v. 33, n. 1, p. 181-188, 2010.

CEN, P.; XIA, L. Production of cellulase by solid-state fermentation. Adv. Biochem. Eng./ Biotechnol., v. 65, p. 69-92, 1999.

CHAGAS, C. F. D. Técnica de processo para a viabilização econômica do processo de hidrólise. In: I SEMINÁRIO DE ETANOL CELULÓSICO, 2007, São Paulo.

CHAHAL, D. S. Solid-State Fermentation with Trichoderma-Reesei for Cellulase Production. Appl. Environ. Microbiol., v. 49, p. 205-210, 1985.

CHARLESBY, A. Crosslinking and degradation of polymers. Radiat. Phys. Chem., v. 18, p. 59-66, 1981.

CHOSDU, R.; HILMY, N. E.; ERLINDA, T. B.; ABBAS, B. Radiation and chemical pretreatment of cellulosic waste. Radiat. Phys. Chem., v. 42, p. 695-698, 1993.

CHUMPING, Y.; ZHIQIANG, S.; GUOCE, Y.; JIANLONG, W. Effect and aftereffect of radiation pretreatment on enzymatic hydrolysis of wheat straw. Bioresour. Technol., v. 99, p. 6240-6245, 2008. 
CORRETORA MERCADO. Cotações de cereais. Disponível em $<$ http://www.bmrs.com.br/novo/cotacoes/buscacot.asp $>$. Acesso em: Janeiro, 2012.

COUTO, S. R.; SANROMÁN, M. A. Application of solid-state fermentation to food industry - a review. J. Food Eng., v. 76, p. 291-302, 2006.

DESCHAMPS, F.; GIULIANO, C.; ASTHER, M.; HUET, M. C.; ROUSSOS, S. Cellulase Production by Trichoderma Harzianum in Static and Mixed Solid-State Fermentation Reactors under Nonaseptic Conditions. Biotechnol. Bioeng., v. 27, n. 9, p. 1385-1388, 1985.

DESGRANGES, C.; GEORGES M.; VERGOIGNAN, C.; DURAND, A. Biomass Estimation in Solid-State Fermentation. II. Online Measurements. Appl. Microbiol. Biotechnol., v.35, n.2, p.206-209. 1991.

DÍAZ, A. B.; CARO, I.; ORY, I.; BLANDINO, A. Evaluation of the conditions for the extraction of hydrolitic enzymes obtained by solid state fermentation from grape pomace. Enzyme Microb. Technol., v. 41, p. 302-306, 2007.

DILLON, A. J. P.; BETTIO, M.; POZZAN, F. G.; ANDRIGHETTI, T. CAMASSOLA, M. A new Penicillium echinulatum strain with faster cellulase secretion obtained using hydrogen peroxide mutagenesis and screening with 2-deoxyglucose. J. Appl. Microbiol., v. 111, p. 48-53, 2011.

DILlON, A. J. P.; ZORGI, C.; CAMASSOLA, M.; HENRIQUES, J. A. P. Use of 2deoxyglucose in liquid media for the selection of mutant strains of Penicillium echinulatum producing increased cellulase and $\beta$-glucosidase activities. Appl. Microbiol. Biotechnol., v. 70, p. 740-746, 2005.

DUFF, S. J. B.; COOPER, D. G.; FULLER, O. M. Effect of media composition and growth conditions on production of cellulase and $\beta$-glucosidase by a mixed fungal fermentation. Enzyme Microb. Technol, v. 9, n. 1, p. 47-52, 1987.

DUFF, S. J. B.; MURRAY, W. D. Bioconversion of forest products industry waste cellulosics to fuel ethanol: A review. Bioresour. Technol., v. 55, p. 1-33, 1996. 
DURAND, A. Bioreactor designs for solid state fermentation, Biochem. Eng. J., v. 13, p. 113-125, 2003.

DURAND, A.; CHEREAU, D. A New pilot reactor for solid-state fermentation: application to the protein enrichment of sugar beet pulp. Biotechnol. Bioeng., v. 31, p. 476486, 1988.

ERIKSSON, T., BORJERSSON, J., TJERNELD, F. Mechanism of surfactant effect in enzymatic hydrolysis of lignocelluloses. Enzyme Microb. Technol., v. 31, n. 3, p. 353-364, 2002.

ESTERBAUER, H.; STEINER, W.; LABUDOVA, I.; HERMANN, A.; HAYN, M. Production of Trichoderma Cellulase in Laboratory and Pilot Scale. Bioresour. Technol., v. 36, p. 51-65, 1991.

FAN, L. T.; LEE, H.Y.; BEARDMORE, D.H. Major Chemical and physical features of cellulosic materials as substrates for enzymatic hydrolysis. Adv. Biochem. Eng., v. 14, p. 101-117, 1980.

FAN, Z. L.; SOUTH, C.; LYFORD, K.; MUNSIE, J.; VAN WALSUM, P.; LYND, L. R. Conversion of paper sludge to ethanol in a semicontinuous solids-fed reactor. Bioprocess Biosyst. Eng., v. 26, p. 93-101, 2003.

FENGEL, D.; WEGENER, G. Wood Chemistry, Ultrastructure and Reactions, Berlin: Walter de Gruyter, 1989.

FERNÁNDEZ-FERNÁNDEZ, M.; PÉREZ-CORREA, J. R. Realistic model of a solid substrate fermentation packed-bed pilot bioreactor. Process Biochem., v. 42, p. 224-234, 2007.

GHILDYAL, N. P.; RAMAKRISHNA, M.; LONSANE, B. K.; KARANTH, N. G. Efficient and simple extraction of mouldy bran in the pulsed column extractor for recovery of amyloglucosidase in concentrated form. Process Biochem., v. 26, p. 235$241,1991$.

GHOSE, T. K. Measurement of cellulase activities. Pure Appl. Chem., v. 59, n. 2, p. 257-268, 1987. 
GOMES, E.; AGUIAR, A. P.; BOSCOLO, M.; CARVALHO, C. C.; SILVA, R.; BONFÁ, M. R. B. Ligninases production by basidiomicetes strains on lignocellulosic agricultural residues and decolorization of synthetic dyes. Braz. J. Microbiol., v. 40, n. 1, p. 31-39, 2009.

GONG, C. S.; LADISEH, M. R.; TSAO, T. G. Biosynthesis, purification and mode of action cellulases of Trichoderma reesei. Adv. Chem. Ser., v. 181, p. 261-287, 1979.

GRAJEK, W. Hyperproduction of thermostable beta-glucosidase by Sporotrichum (Chrysosporium) thermophile. Enzyme Microbiol. Technol., v. 9, p. 744-748, 1987.

GREGG, D. J.; SADDLER, J. N. Factors affecting cellulose hydrolysis and the potential of enzyme recycle to enhance the efficiency of an integrated wood to ethanol process. Biotechnol. Bioeng., v. 51, p. 375-383, 1996.

GUTIERREZ-CORREA, M; TENGERDY, R.P. Production of cellulase on sugar cane bagasse by fungal mixed culture solid substrate fermentation. Biotechnol. Lett., v. 19, p. 665-667, 1997.

HAAB, D.; HAGSPIEL, K.; SZAKMARY, K.; KUBICEK, C. P. Formation of the extracellular proteases from Trichoderma reesei QM 9414 involved in cellulase degradation. J. Biotechnol., v. 16, n. 3-4, p. 87-198, 1990.

HAMIDI-ESFAHANI, Z.; SHOJAOSADATI, S. A.; RINZEMA, A. Modelling of simultaneous effect of moisture and temperature on $A$. niger growth in solid-state fermentation. Biochem. Eng. J., v. 21, p. 265-272, 2004.

HARDIN, M. T.; HOWES, T.; MITCHELL, D. A. Mass transfer correlations for rotating drum bioreactors, J. Biotechnol., v. 97, p. 89-101, 2002.

HAYWARD, T. K.; HAMILTON, J.; TEMPLETON, D.; JENNINGS, E.; RUTH, M.; THOLUDUR, A.; MCMILLAN, J. D.; TUCKER, M.; MOHAGHEGHI, A. Enzyme production, growth, and adaptation of $T$. reesei strains QM9414, L-27, RL-P37, and Rut C-30 to conditioned yellow poplar sawdust hydrolysate. Appl. Biochem. Biotechnol., v. 77, n. 9, p. 293-309, 1999. 
HECK, J. X.; HERTZ, P. F.; AYUB, M. A. Z. Extraction optimization of xylanases obtained by solid-state cultivation of Bacillus circulans BL53. Process Biochem., v. 40, p. 2891-2895, 2005.

HIMMEL, M. E.; RUTH, M. F.; WYMAN, C. E. Cellulase for commodity products from cellulosic biomass. Curr. Opin. Biotechnol., v.10, p. 358-364, 1999.

HSU, T. A. Pretreatment of biomass. In: Handbook on Bioethanol - Production and Utilization. Editado por: Wyman, C.E. Washington, DC, EUA: Taylor \& Francis, 1996, p. 179-212.

IKASARI, L.; MITCHELL, D. A. Leaching and characterization of Rhizopus oligosporus acid protease from solid-state fermentation. Enzyme Microb. Technol., v. 19, p. 171-175, 1996.

JORGENSEN, H.; VIBE-PEDERSEN, J.; LARSEN, J.; FELBY, C. Liquefaction of lignocellulose at high-solids concentrations. Biotechnol. Bioeng., v. 96, n. 5, p. 862-870, 2006.

KATZEN, R.; MADSON, P. W.; MOON, G. D. Alcohol destillation-The fundamentals. In: The alcohol textbook. Nottingham: Nottingham University Press, 1999, p. 103-125.

KHAN, F.; AHMADA, S. R.; KRONFLI, E. Y Radiation induced changes in the physical and chemical properties of lignocellulose. Biomacromolecules, v.7, p. 23032309, 2006.

KHANDKE, K. M.; VITHAYATHIL, P. J.; MURTHY, K. S. Purification of xylanase, $\beta$ glucosidase, endocellulase and exocellulase from thermophilic fungus, Thermoascus aurantiacus. Arch. Biochem. Biophys., v. 274, p. 491-500, 1989.

KIRK, O.; BORCHERT, T. V.; FUGLSANG, C. C. Industrial enzyme applications. Curr. Opin. Biotechnol., v. 13, p. 345-351, 2002.

KOUTINAS, A.A.; WANG, R.; WEBB, C. Estimation of fungal growth in complex, heterogeneous culture. Biochem. Eng. J., v. 14, n. 2, p. 93-100, 2003. 
KOVACS, K.; MACRELLI, S.; SZAKACS, G.; ZACCHI, G. Enzymatic hydrolysis of steam-pretreated lignocellulosic materials. Biotechnol. Biofuels, v. 2, 14 p., 2009.

KRISHNA, C. Solid-State Fermentation Systems - An Overview. Crit. Rev. Biotechnol., v. 25, p. 1-30, 2005.

KUMAR, P. K. R.; LONSANE, B. K.. Extraction of gibberellic acid from dry mouldy bran produced under solid state fermentation. Process Biochem., v. 22, p. 139-143, 1987.

KUMAR, P.; BARRETT, D. M.; DELWICHE, M. J.; STROEVE, P. Methods for pretreatment of lignocellulosic biomass for efficient hydrolysis and biofuel Production. Ind. Eng. Chem. Res., v. 48, p. 3713-3729, 2009.

KUMAR, S.; NUSSINOV, R. How do thermophilic proteins deal with heat? A review. Cell. Mol. Life Sci., v. 58, p. 1216-1233, 2001.

LAMED, R.; BAYER, E. A. The cellulosome of Clostridium thermocellum. Adv. Appl. Microbiol., v. 33, p. 1-46, 1988.

LEE, J. Biological conversion of lignocellulosic biomass to ethanol. J. Biotechnol., v. 56, p. 1-24, 1997.

LEHNINGER, A. L. Biochemistry: the molecular basis of cell structure and function. New York: Worth Publishers, 1985, 833p.

LIU, J.; YANG, J. Cellulase production by Trichoderma koningii AS3.4262 in solid-state fermentation using lignocellulosic waste from the vinegar industry. Food Technol. Biotechnol., v. 45, n. 4, p. 420-425, 2007.

LONSANE, B. K.; GHILDYAL, N. P.; BUDIATMAN, S.; RAMAKRISHNA, S. V. Enginnering aspects of solid-state fermentation. Enzyme Microb. Technol., v. 7, p. 258-265, 1985.

LONSANE, B. K.; SAUCEDO-CASTANEDA, S.; RAIMBAULT, M.; ROUSSOS, S.; VINIEGRA-GONZALEZ, G.; GHILDYAL, N. P.; RAMAKRISHNA, M.; 
KRISHNAIAH, M. M. Scale-up strategies for solid state fermentation systems. Process Biochem., v. 27, p. 259-273, 1992.

LU, Z.; KUMAKURA, M. Effect of radiation pretreatment on enzymatic hydrolysis of rice straw with low concentrations of alkali solution. Bioresour. Technol., v. 43, p. 13-17, 1993.

MACEDO, I. A energia da cana-de-açúcar (Sugarcane's energy: twelve studies on Brazilian sugar cane agrobussiness and its sustentability). UNICA (Sao Paulo Sugarcane Agroindustry Union), São Paulo, Brasil, 2005.

MAIORANO. A. E. Produção de Pectinases por Fermentação em Estado Sólido. Tese (Doutorado em Engenharia Química) - Escola Politécnica, Universidade de São Paulo, São Paulo, 1990.

MANDELS, M.; REESE, E.T. Fungal cellulases and the microbial decomposition of cellulose fabri. Dev. Ind Microbiol., v. 5, p. 5-20, 1964.

MARQUES, F. O alvo é o bagaço: Subproduto abundante da indústria da cana dá vantagem competitiva ao Brasil na busca do etanol de segunda geração. Revista Pesquisa FAPESP, Edição Impressa 163, 2009.

MARTIN, C.; GALBE, M.; WAHLBOM, F.; HAHN-HAGERDAL, B.; JOHSSIM, L.J. Ethanol production from enzymatic hydrolysates of sugarcane bagasse using recombinant xylose-utilising Saccharomyces cerevisiae. Enzyme Microb. Technol., v. 31, p. 274-282, 2002.

MEKALA, N.K; SINGHANIA, R.R.; SUKUMARAN, R.K.; PANDEY, A. Cellulase production under solid-state fermentation by Trichoderma reesei RUT C30: Statistical optimization of process parameters. Appl. Biochem. Biotechnol., v. 151, p. 122-131, 2008.

MITCHELL, D. A.; KRIEGER, N.; BEROVIC, M. Solid-State Fermentation Bioreactors: Fundamentals of Design and Operation. Berlin: Springer, 2006, 447 p.

MITCHELL, D. A.; KRIEGER, N.; STUART, D. M.; PANDEY, A. New developments in solid-state fermentation II. Rational approaches to the design, operation and 
scale-up of bioreactors. Process Biochem., v. 35, p. 1211-1225, 2000.

MITCHELL, D. A.; PANDEY, A.; SANGSURASAK, P.; KRIEGER, N. Scale-up strategies for packed-bed bioreactors for solid-state fermentation. Process Biochem., v. 35, p.167-178, 1999.

MO, H.; ZHANG, X; LI, Z. Control of gas phase for enhanced cellulase production by Penicillium decumbens in solid-state culture. Process Biochem., v. 39, p. 12931297, 2004.

MOHAGHEGHI, A.; TUCKER, M.; GROHMANN, K.; WYMAN, C. High solids simultaneous saccharification and fermentation of pretreated wheat straw to ethanol. Appl. Biochem. Biotechnol., v. 33, p. 67-81, 1992.

MORETTI, M. M. S. Isolamento de fungos termofílicos produtores de celulases, xilanases e ferruloil esterase para bioconversão de bagaço de cana-deaçúcar em açúcares fermentescíveis. Dissertação (Mestrado em Microbiologia Aplicada) - Instituto de Biociências, UNESP, Rio Claro, 2010.

MOSIER, N. S.; WYMAN, C.; DALE, B.; ELANDER, R.; LEE, Y. Y.; HOLTZAPPLE, M.; LADISCH, M. R. Features of promising technologies for pretreatment of lignocellulosic biomass. Bioresour. Technol., v. 96, p. 673-686, 2005.

MUSSATTO, S. I.; FERNANDES, M.; MILAGRES, A. M. F. Enzimas, poderosa ferramenta na indústria. Ciência Hoje, v. 41, n. 242, p. 28-33, 2007.

OGAWA, K.; TOYAMA, N. Resolution of the Trichoderma viride cellulolytic complex. J. Ferment. Technol., v. 45, p. 671-680, 1972.

OLOFSSON, K.; BERTILSSON, M.; LIDEN, G. A short review on SSF - an interesting process option for ethanol. BioMed Central, v. 1, 7 p., 2008.

OLSSON, L.; HAHN-HAGERDAL, B. Fermentation of lignocellulosic hydrolysates for ethanol production. Enzyme Microb. Technol., v. 18, n. 5, p. 312-331, 1996.

OOIJKAAS, L. P.; TRAMPER, J.; BUITELAAR, R. Biomass estimation of Coniothyrium minitans in solid state fermentation. Enzyme Microb. Technol., v. 22, p. 480- 
486, 1998.

OOIJKAAS, L. P.; WEBER, F. J.; BUITELAAR, R.; TRAMPER, J.; RINZEMA, A. Defined media and inert supports: Their potential as solid-state fermentation production systems. Tibtech, v. 18, p. 356-360, 2000.

ORIOL, E.; RAIMBAULT, M.; ROUSSOS, S.; VINIEGRA-GONZALES, G. Water and water activity in the solid-state fermentation of cassava starch by Aspergillus niger. Appl. Microbiol. Biotechnol., v. 27, p. 498-503, 1988.

PANDEY, A. Solid-state fermentation. Biochem. Eng. J., v. 13, p. 81-84, 2003.

PANDEY, A.; SELVAKUMAR, P.; SOCCOL, C. R.; NIGAM, P. Solid-state fermentation for the production of industrial enzymes. Curr. Sci., v. 77, n. 1, p. 149-162, 1999.

PANDEY, A.; SOCCOL, C. R.; NIGAM, P.; SOCCOL, V. T. Biotechnological potential of agro-industrial residues. I: sugarcane bagasse. Bioresour. Technol., v. 74, n.1, p. 69-80, 2000.

PARSONS, C. M.; ZHANG, Y.; ARABA, M. Nutritional evaluation of soybean meals varying in oligosaccharide content. Poultry Sci., v. 79, p. 1127-1131, 2000.

PHILLIPPIDIS, G. P.; SMITH, T. K.; WYMAN, C.E. Study of the enzymatic hydrolysis of cellulose for production of fuel ethanol by the simultaneous saccharification and fermentation process. Biotechnol. Bioeng., v. 41, p. 846-853, 1992.

PIRT, J. S. Principles of Microbe and Cell Cultivation. Oxford: Blackwell Scientific Publications, 1975.

RAIMBAULT, M. General and microbiological aspects of solid substrate fermentation. Elect. J. Biotech., v. 1, p. 1-15, 1998.

RAMADAS, M.; HOLST, O.; MATTIASSON, B. Extraction and purification of amyloglucosidase produced by solid state fermentation with Aspergillis niger. Biotechnol. Tech., v. 9, p. 901-906, 1995. 
RAMAKRISHNA, S. V.; SUSEELA, T.; GHILDYAL, N. P.; JALEEL, S. A.; PREMA, P.; LONSANE, B. K.; AHMED, S. Y. Recovery of amyloglucosidase from moldy bran. Indian J. Technol., v. 20, p. 476-480, 1982.

REZAEI, F.; JOH, L. D.; KASHIMA, H.; REDDY, A. P.; VANDERGHEYNST, J. S. Selection of Conditions for Cellulase and Xylanase Extraction from Switchgrass Colonized by Acidothermus cellulolyticus. Appl. Biochem. Biotechnol., v. 164, p. 793-803, 2011.

RODRIGUEZ-LEON, J. A., SASTRE, L.; ECHEVARRIA, J.; DELGADO, G.; BECHSTEDT, W. A mathematical approach for the estimation of biomass production-rate in solid-state fermentation. Acta Biotechnol., v. 8, n. 4, p. 307310, 1988.

SAHIR, A. H.; KUMAR, S.; KUMAR, S. Modelling of a packed bed solid-state fermentation bioreactor using the $\mathrm{N}$-tanks in series approach, Biochem. Eng. J., v. 35, n. 1 , p. $20-28,2007$.

SANGSURASAK, P.; MITCHELL, D. A. Validation of a model describing two dimensional dynamic heat transfer during solid-state fermentation in packed bed bioreactors. Biotechnol. Bioeng., v. 60, n. 6, p. 739-749, 1998.

SAUCEDO-CASTENEDA, G.; GUTIERREZ-ROJAS, M.; BACQUET, G.; RAIMBAULT, M.; VINIEGRA-GONZALEZ, G. Heat transfer simulation in solid substrate fermentation. Biotechnol. Bioeng., v. 35, p. 802-808, 1990.

SINGHANIA, R. R.; PATEL, A.K.; SOCCOL, C.R.; PANDEY, A. Recent advances in solid-state fermentation. Biochem. Eng. J., v. 44, p. 13-18, 2009.

SINGHANIA, R. R.; SUKUMARAN, R.K.; PATEL, A.K.; LARROCHE, C.; PANDEY, A. Advancement and comparative profiles in the production technologies using solidstate and submerged fermentation for microbial cellulases. Enzyme Microb. Technol., v. 46, p. 541-549, 2010.

SMITS, J. P.; RINZEMA, A.; TRAMPER, J.; VANSONSBEEK, H. M.; HAGE, J.C.; KAYNAK, A.; KNOL, W. The influence of temperature on kinetics in solid-state fermentation. Enzyme Microb. Technol., v. 22, p. 50-57, 1998. 
SMITS, J. P.; RINZEMA, A.; TRAMPER, J.; VANSONSBEEK, H. M.; KNOL, W. Solidstate fermentation of wheat bran by Trichoderma reesei QM9414: substrate composition changes, $\mathrm{C}$ balance, enzyme production, growth and kinetics. Appl. Microb. Biotechnol., v. 46, n. 5-6, p. 489-496, 1996.

STENBERG, K.; TENGBORG, C.; GALBE, M.; ZACCHI, G. Optimization of steam pretreatment of $\mathrm{SO} 2$ impregnated mixed softwoods for ethanol production. $\mathbf{J}$. Chem. Technol. Biotechnol., v. 71, p. 299-308, 1998.

STERNBERG, D.; MANDELS, G. R. Induction of cellulolytic enzymes in Trichoderma reesei by sophorose. J. Bacteriol., v. 139, p. 761-769, 1979.

SUGDEN, C.; BHAT, K. M. Cereal straw and pure cellulose as carbon sources for growth and production of plant cell wall degrading enzymes by Sporotrichum thermophile. World J. Microbiol. Biotechnol., v. 10, p. 444-451, 1994.

SUKUMARAN, R. K.; SINGHANIA, R. R.; PANDEY, A. Microbial cellulases: production, applications and challenges. J. Sci. Ind. Res., v. 64, p. 832-844, 2005.

SUN, Y.; CHENG, J. Hydrolysis of lignocellulosic materials for ethanol production: a review. Bioresour. Technol., v. 83, p. 1-11, 2002.

TAHERZADEH, M. J.; KARIMI, K. Pretreatment of lignocellulosic wastes to improve ethanol and biogas production: A Review. Int. J. Mol. Sci., v. 9, p. 1621-1651, 2008.

TENGBORG, C.; GALBE, M.; ZACCHI, G. Influence of enzyme loading and physical parameters on the enzymatic hydrolysis of steam-pretreated softwood. Biotechnol. Prog., v. 17, n. 1, p. 110-117, 2001.

URBANSZKI, K.; SZAKACS, G.; TENGERDY, R. P. Standardization of the filter paper activity assay for solid substrate fermentation. Biotechnol. Lett., v. 22, n. 1, p. 65-69, 2000.

VINIEGRA-GONZALEZ, G.; FAVELA-TORRES, E.; AGUILAR, C. N.; ROMEROGOMEZ, S. D.; DIAZ-GODINEZ, G.; AUGUR, C. Advantages of fungal enzyme production in solid-state over liquid fermentation systems. Biochem. Eng. J., v. 13, p. 157-167, 2003. 
WEN, Z.; LIAO, W.; CHEN, S. Production of cellulase/ $\beta$-glucosidase by the mixed fungi culture Trichoderma reesei and Aspergillus phoenicis on dairy manure. Process Biochem., v. 40, p. 3087-3094, 2005.

WENZIG, E.; LINGG, S.; KERZEL, P.; ZEH, G.; MERSMANN, A. Comparison of selected methods for downstream processing in the production of bacterial lipase. Chem. Eng. Technol., v. 16, p. 405-412, 1993.

WINGREN, A.; GALBE, M.; ZACCHI, G. Techno-economic evaluation of producing ethanol from softwood: Comparison of SSF and SHF and identification of bottlenecks. Biotechnol. Prog., v. 19, p. 1109-1117, 2003.

WOOD, T. M. The cellulase of Fusarium solani. Resolution of the enzyme complex. Biochem. J., v. 115, p. 457-464, 1969.

WOOD, T. M.; MCCRAE, S. I. The cellulase of Penicillium pinophilum: Synergism between enzyme components in solubilizing cellulose with special reference to the involvement of two immunologically distinct cellobiohydrolases. Biochem. J., v. 234, p. 93-99, 1986.

WYMAN, C. E. Ethanol from lignocellulosic biomass: Technology, economics, and opportunities. Bioresour. Technol., v. 50, p. 3-16, 1994.

YADAV, J. S. SSF of wheat straw with alcaliphilic Coprinus. Biotechnol. Bioeng., v. 31, p. 414-417, 1988.

YANG, S. S.; CHIU, W. F. Protease production with starchy agricultural wastes by solid state fermentation. Microbe, p. 283-286 Int. Cong. Microbiology, 14 Meet, 1987.

ZHAO, X.; PENG, F.; CHENG, K.; LIU, D. Enhancement of the enzymatic digestibility of sugarcane bagasse by alkali-peracetic acid pretreatment. Enzyme Microb. Technol., v. 44, p. 17-23, 2009.

ZHENG, Y.; PAN, Z. L.; ZHANG, R. H.; WANG, D. H.; JENKINS, B. Non-ionic surfactants and non-catalytic protein treatment on enzymatic hydrolysis of pretreated creeping wild ryegrass. Appl. Biochem. Biotechnol., v. 146, n. (1-3), p. 231-248, 2008. 


\section{APÊNDICE A - ARTIGO SUBMETIDO PARA PUBLICAÇÂO \\ MICROORGANISMS AND MEDIA FOR CELLULASE PRODUCTION IN SOLID STATE CULTURES \\ B. V. Kilikian ${ }^{1, *}$, L. C. Afonso ${ }^{1}$, T. F. C. Souza ${ }^{1}$, R. G. Ferreira ${ }^{1}$, I. R. Pinheiro ${ }^{2}$}

${ }^{1}$ Chemical Engineering Department, University of São Paulo (USP), P.O. Box 61548, 05424970, SP, BRAZIL.

${ }^{2}$ Agricultural Engineering Department, Agricultural Science Center, Federal University of Espirito Santo (UFES), P.O. Box16, Guararema, 2950¹0-000, ES, BRAZIL.

\section{Abstract}

Cellulase production was evaluated in two reference strains ( $T$. reesei Rut-C30 and $T$. reesei QM9414), two strains isolated from a sugarcane cultivation area (Trichoderma sp. IPT778 and T. harzianum rifai IPT821) and one strain isolated in a program for biodiversity preservation in São Paulo state (Myceliophthora sp. M77). Solid state cultures were performed using sugarcane bagasse (C), wheat bran (W) and/or soybean bran (S). The highest FPA was $10.6 \mathrm{U} / \mathrm{gdm}$ for $\mathrm{M} 77$ in SC(10:90) at $80 \%$ moisture, which was 3.5 times higher than production in pure W. C was a strong inducer of cellulase production, given that the production level of $6.1 \mathrm{U} / \mathrm{gdm}$ in WC (40:60) was 2.5 times higher than in pure $\mathrm{W}$ for strain M77; T. reesei Rut-C30 did not respond as strongly with about 1.6 -fold surplus production. $S$ advantageously replaced $\mathrm{W}$, as the surplus production on SC (20:80) was 2.3 times relative to WC (20:80) for M77.

\section{Key Words}

Cellulases; productivity; solid media; sugarcane bagasse; Myceliophtora sp.

Abbreviations: SmC, Submerged Cultures; SSC, Solid State Cultures; C, sugarcane bagasse; W, wheat bran; $\mathrm{S}$, soybean bran; FPA, filter paper activity; $\mathrm{C}_{\mathrm{FPA}}$, cellulase concentration; $\mathrm{P}_{\mathrm{R}}$, cellulase productivity; $T$., Trichoderma; gdm, gram of dry matter.

*Corresponding author. Tel.: 5511 30912282; fax: 551130912284.

E-mail address: kilikian@usp.br 


\section{Introduction}

Cellulases are enzymes largely focused on by researchers and industries, as they are used in various economically relevant processes. The hydrolytic action of cellulases on cellulose, a linear polysaccharide polymer with many glucose monosaccharide units, renders free monosaccharides not only for liquid fuel production, but also for the production of other chemicals, some of them potential substitutes for petroleum derivatives (Bozell and Petersen, 2010).

The proposal to convert sugars from biomass into liquid fuels, mainly ethanol and petroleum derivatives, is not new. Since the first oil crisis in the 1970s, governments and scientists have invested in alternative sources of petroleum, which have relied mostly on biomass. Oil price regularization and its availability reduced the interest in biomass for more than 20 years, until geopolitical instabilities and environmental concerns renewed interest in biomass utilization.

Regarding the applications of cellulases in processes for which products must have low and competitive prices, their production process must be defined for each specific region and final use. There is a consensus among researchers that in order to make the market price of ethanol produced from biomass viable, cellulase production must be done "in situ", that is, at the ethanol production plant. In this case, is important to explore the application of sugarcane bagasse for cellulase synthesis in Brazil.

According to Galbe et al. (2007), culture medium costs can be a significant fraction of the enzyme cost if an expensive substrate is applied. Although cheap substrates, such as sugarcane bagasse, are less important to the enzyme cost, they must be carefully chosen as the substrate influences enzyme productivity, an important fraction of the enzyme cost. Productivity defines the size of the reactors, which, in turn, are a major part of the capital investment. As stated by Himmel et al. (1999), productivity of cellulase in submerged culture (SmC) must be as high as $200 \mathrm{U} / \mathrm{L} / \mathrm{h}$, which drives the fraction of the enzyme cost to no higher than US\$0.20 per gallon of ethanol.

Cellulases, as well as other enzymes, are excellent microbial products for solid state cultivation when produced by filamentous fungi, because hyphae have the natural ability to cover the solid nutritive surface of the substrate and even to enter its pores, and thus become strongly attached to the substrate (Raimbault, 1998). The easy growth 
of filamentous fungi on solid media relies on the high capacity of hydrolytic enzyme synthesis in the media along with a high content of polymerized sugars, which are the inducers of gene expression of these enzymes. The ordinary content of cellulose in abundant natural crop residues, such as sugarcane bagasse and rice straw, is about $40 \% \mathrm{w} / \mathrm{w}$ (Cen and Xia, 1999). When these residues are used as substrates for solid state cultures (SSC), the cellulose concentration in the medium is around 6-28\%, considering that moisture levels vary between 30 and $85 \%$ (Krishna, 2005), while for $\mathrm{SmC}$, the maximum cellulose concentration is about 0.5 to $6 \%$ (Chahal, 1984). Therefore, the induction of cellulase synthesis has reduced power in SmC relative to SSC.

Substrates of solid state cultures, besides being strong inducers of cellulase synthesis, also induce hemicellulases such as xylanases and ligninases, if the solid substrate is composed of hemicellulose and lignin. Therefore, SSC can result in a more diverse pool of hydrolytic enzymes than SmC. Finally, solid state media are interesting to make good use of the huge amounts of sugarcane bagasse available in Brazil. According to UNICA (Brazil's Union of Sugar Cane Industries), in 2010/2011, the southcentral region of Brazil alone processed about 557 million tons of sugar cane, producing around 157 million tons of bagasse.

The objective of this study was to evaluate microorganisms and substrates for cellulase production in SSC, in media consisting mainly of sugarcane bagasse, in addition to wheat bran and soybean bran; wheat bran was also applied solely in order to allow comparisons with published data. Besides investigating microorganisms evaluated in various publications, Trichoderma reesei Rut-C30 and Trichoderma reesei QM9414, novel microorganisms were evaluated, such as Trichoderma sp. IPT778, Trichoderma harzianum rifai IPT821, and the recently isolated Myceliophthora sp. M77. Data were analyzed regarding production $(\mathrm{U} / \mathrm{gdm})$, productivity $(\mathrm{U} / \mathrm{gdm} / \mathrm{h})$, and stability of cellulases.

\section{Materials and Methods}


Microorganisms and inoculum. Five microorganisms, Trichoderma reesei Rut-C30 (ATCC 56765), Trichoderma reesei QM9414 (ATCC 26921), Trichoderma sp. IPT778, Trichoderma harzianum rifai IPT821 - the latter two isolated in a sugar cane cultivation area, SP, Brazil - and Myceliophthora sp. M77, recently isolated through an environmental program for biodiversity preservation in the State of São Paulo (BIOTA FAPESP), were maintained in stock on a solid medium made of wheat bran and sugarcane bagasse $(20: 80 \mathrm{w} / \mathrm{w})$. One gram of the stock medium containing the spores of each microorganism was suspended in $100 \mathrm{~mL}$ of an $\mathrm{NaCl}$ solution $0.9 \%(\mathrm{w} / \mathrm{w})$ and this suspension was applied as the inoculum for the SSC.

Culture media. Culture media were made of combinations of sugarcane bagasse $(C)$, wheat bran (W) and soybean bran (S), the compositions of which on a dry mass basis (w:w) were as follows: W (100); WC (90:10); WC (80:20); WC (40:60); WC (60:40); SC (10:90) and SC (20:80).

Sugarcane bagasse in natura (Usina Iracema, Iracemápolis, São Paulo, Brazil) with $50 \%$ moisture on a wet basis was stored at $-20^{\circ} \mathrm{C}$ in order to prevent microbial proliferation (Roussos et al., 1991). Upon utilization, the sugar cane bagasse was dried at $50^{\circ} \mathrm{C}$ to $6 \%$ moisture, in order to allow the adjustment of initial moisture of the cultivation to $60 \%$, after the addition of the spore suspension and a salt solution. The granulometry of dry sugarcane bagasse to formulate the culture medium was obtained through sieving and selection of the fraction retained between 10 and 20 mesh.

Wheat bran at $13 \%$ moisture on a wet basis was supplied by "Anaconda Industrial e Agrícola de Cereais" (São Paulo, Brazil) and soybean bran at $11 \%$ moisture was supplied by "Coama Agroindustrial Cooperativa" (Paraná, Brazil). The two types of bran were stored at room temperature as low moisture protects them from microbial proliferation. Upon use, they were dried to allow further moisture adjustment with the addition of the spore suspension and a salt solution, to an initial value of 60 or $80 \%$ on a wet basis. Both types of bran were sieved between 8 and 20 mesh.

Cultures. Solid-state cultures were made in $500 \mathrm{~mL}$ Erlenmeyer flasks with $7 \mathrm{~g}$ of culture medium plus a salt solution, and sterilized by autoclaving at $121^{\circ} \mathrm{C}$ for 20 min before 
inoculation with a sufficient volume of the spore suspension to obtain $10^{7} \mathrm{spores} / \mathrm{gdm}$. Initial moisture was adjusted with a salt solution (Urbánszki, 2000): $5 \mathrm{~g} / \mathrm{L} \mathrm{KH}_{2} \mathrm{PO}_{4} ; 5 \mathrm{~g} / \mathrm{L}$ $\left(\mathrm{NH}_{4}\right) 2 \mathrm{SO}_{4} ; 1 \mathrm{~g} / \mathrm{L} \mathrm{MgSO} 4 \cdot 7 \mathrm{H}_{2} \mathrm{O} ; 1 \mathrm{~g} / \mathrm{L} \mathrm{NaCl} ; 5 \mathrm{mg} / \mathrm{L} \mathrm{FeSO}_{4} \cdot 7 \mathrm{H}_{2} \mathrm{O} ; 1.6 \mathrm{mg} / \mathrm{L} \mathrm{MnSO}$; $3.45 \mathrm{mg} / \mathrm{L} \mathrm{ZnSO}_{4} \cdot 7 \mathrm{H}_{2} \mathrm{O}$ and $2.0 \mathrm{mg} / \mathrm{L} \mathrm{CoCl}_{2} \cdot 6 \mathrm{H}_{2} \mathrm{O}$. The flasks were kept in an incubator at $30^{\circ} \mathrm{C}$ (all fungi except for Myceliophthora sp. M77) or at $45^{\circ} \mathrm{C}$ (Myceliophthora sp. M77) for 120 hours. Cultivations were entirely made in duplicate, from the spore suspension to the cultures, except for cultures with soybean bran which were made in triplicate. Samples were collected once a day from the first to the third day and after five days of cultivation.

\section{Analytical methods}

Moisture determination. The moisture level was determined by an OHAUS MB 35 Halogen Moisture Analyzer (USA) which operates on the thermogravimetric principle, in which the sample is quickly heated by a halogen drying unit for moisture evaporation. At the end of drying, the result is displayed as percent moisture content on a wet basis.

Enzyme extraction. Enzyme extraction was performed by shaking $\left(180 \mathrm{rpm}, 20^{\circ} \mathrm{C}, 60\right.$ $\min$ ) a mixture of $4 \mathrm{~g}$ of the cultivated medium with $40 \mathrm{~mL}$ of distilled water, $40 \mathrm{~mL}$ of citrate buffer $\mathrm{pH} 4.8$ (for all the fungi except for Myceliophthora sp. M77) or acetate buffer pH 5.0 (Myceliophthora sp. M77), and one drop of Tween 80. After shaking, the sample was filtered under vacuum through S\&S 5802 filter paper $(1.2 \mu \mathrm{m})$ and the enzyme activity of the filtrate was measured.

Enzyme Activity. Measurements of filter paper activity (FPA) were made according to Ghose (1987) and expressed relative to the mass of the culture medium; that is, as a concentration. $\mathrm{C}_{\mathrm{FPA}}$ is the activity concentration in the medium for filter paper activity and was calculated as described in equation 1.

$C_{F P A}(U / g d m)=C_{g} \times \frac{1}{M} \times \frac{1}{t} \times \frac{1}{1-u} \times D$ 
where $C_{g}$ is the measured glucose concentration $(\mathrm{g} / \mathrm{L}) ; M$ is the molecular weight of glucose $(0.18 \mathrm{~g} / \mu \mathrm{mol}) ; \mathrm{t}$ is time interval of reaction of $60 \mathrm{~min}$; $u$ is the moisture of the culture medium (\%) and $\mathrm{D}$ is the dilution of the liquid extract.

Enzyme productivity . Productivity, $P_{R}$, is the enzyme production rate, $(\mathrm{U} / \mathrm{gdm} / \mathrm{h})$, determined as described by equation 2 , where $t$ is the cultivation time for maximum enzyme activity.

$$
P_{R}=\frac{C_{F P A}}{t}
$$

\section{Results and Discussion}

Media and microorganisms for cellulase production

Microorganisms and media made mainly from sugarcane bagasse were evaluated in terms of cellulase production and productivity in solid state cultures. Five strains of filamentous fungi selected for this evaluation had either been investigated in previous publications or had been recently isolated with specific features of interest for cellulase production: (1) Trichoderma reesei Rut-C30 (ATCC 56765); (2) Trichoderma reesei QM9414 (ATCC 26921); (3) Trichoderma sp. IPT778; (4) Trichoderma harzianum rifai IPT82, and (5) Myceliophthora sp. M77.

Wheat bran was applied because it has been reported on in several publications, and was thus considered the reference medium. Also, its high protein content around $17 \%$ and high starch content around $19 \%$ on a dry basis make it an excellent culture medium to provide amino acids, nitrogen, and carbon sources for cellular growth, besides being an excellent support for growth owing to its cellulose and hemicellulose content as high as 39\% (Sun et al. 2008; Brijwani et al. 2010). Soybean bran was applied as it is more available than wheat bran in Brazil, and is also a good source of amino acids and organic nitrogen. According to the supplier, the soybean bran applied to the cultures herein contained $46.55 \%$ protein, $2.16 \%$ lipids, $4.95 \%$ fiber, and $12.6 \%$ moisture.

The mean values and standard deviations from two or three runs for maximum cellulase concentration, $\mathrm{C}_{\mathrm{FPA}}(\mathrm{U} / \mathrm{gdm})$, and maximum cellulase productivity, $\mathrm{P}_{\mathrm{R}}$ 
$(\mathrm{U} / \mathrm{gdm} / \mathrm{h})$, in each culture medium are depicted in Figures 1 to 5 , respectively, for each microorganism.

The data in Figure 1 for Trichoderma reesei Rut-C30 show that the inclusion of sugar cane bagasse (40\%) into a medium made from wheat bran resulted in a $60 \%$ increase in enzyme concentration, that is, from 2.5 to $4.0 \mathrm{U} / \mathrm{gdm}$, while productivity decreased by $40 \%$, from 0.05 to $0.03 \mathrm{U} / \mathrm{gdm} / \mathrm{h}$. The higher enzyme productivity in medium made of $100 \%$ wheat bran was probably due to faster cell growth in a medium enriched with organic nitrogen and amino acids, while cultures on media made with sugarcane bagasse resulted in a higher enzyme concentration. Media made with more than $40 \%(\mathrm{w} / \mathrm{w})$ sugarcane bagasse resulted in lower $\mathrm{C}_{\mathrm{FPA}}$.

The data in Figure 2 for Trichoderma reesei QM9414 show almost the same behavior in media with 40 or $60 \%$ sugarcane bagasse and wheat bran, resulting an $18 \%$ increase in $\mathrm{C}_{\mathrm{FPA}}$ relative to the medium made with pure wheat bran, while $\mathrm{P}_{\mathrm{R}}$ decreased by $25 \%$, from 0.08 to $0.06 \mathrm{U} / \mathrm{gdm} / \mathrm{h}$. It is worth noting that although the general behavior was the same as that of Trichoderma reesei Rut-C30, the significance of the variations was less pronounced, indicating that the strain Trichoderma reesei QM9414 was less sensitive to those media than Trichoderma reesei Rut-C30.

Almost the same results as for Trichoderma reesei Rut-C30 and Trichoderma reesei QM9414 were found for Trichoderma sp. IPT778 (Figure 3) and Trichoderma harzianum rifai IPT821 (Figure 4). However, the improvement in enzyme concentration for strain Trichoderma sp. IPT778 was remarkable, 117\%, from 1.7 to $3.7 \mathrm{U} / \mathrm{gdm}$ upon the inclusion of $40 \%$ sugarcane bagasse into the medium; this was an extremely inducible strain.

Myceliophtora sp. M77 (data in Figure 5) was cultivated in the same media applied for the four aforementioned microorganisms, plus SC (10:90) and SC (20:80) at $60 \%$ moisture, and SC (10:90) at 80\% moisture. Regarding the media made with wheat bran and wheat bran plus sugarcane bagasse, a similar behavior for Myceliophtora sp. M77 as for the other microorganisms was seen, with enzyme production in media with $\mathrm{C}$ $40 \%$ and $\mathrm{C} 60 \%$ higher than in medium with $\mathrm{W} 100 \%$. The highest $\mathrm{C}_{\mathrm{FPA}}$ in media with $\mathrm{C}$ $60 \%$ was $308 \%$ greater than in W $100 \%$, as it increased from 2.4 to $6.1 \mathrm{U} / \mathrm{gdm}$. In this case, the $P_{R}$ also improved, from 0.05 to $0.13 \mathrm{U} / \mathrm{gdm} / \mathrm{h}$, a $160 \%$ increase. 
Myceliophtora sp. M77 cultures made in SC (10:90) and SC (20:80) media resulted in higher cellulase production than in media with $\mathrm{W}$ and $\mathrm{C}$, in the same proportions, as clearly illustrated in Figure 5 . Therefore, $\mathrm{S}$ was better than $\mathrm{W}$ for enzyme production, a performance that could be due to the higher protein content in $\mathrm{S}$, which probably enhanced growth and protein synthesis. Besides, medium with $S$ as low as $10 \%$ was remarkably better for cellulase production compared to media made of $10 \% \mathrm{~W}$.

Increasing the moisture of the SC (10:90) medium from 60 to $80 \%$ resulted in a $\mathrm{C}_{\mathrm{FPA}}$ of $10.6 \mathrm{U} / \mathrm{gdm}$, the highest production among all the results presented, while $\mathrm{P}_{\mathrm{R}}$ also remained on the order of the highest values, $0.09 \mathrm{U} / \mathrm{gdm} / \mathrm{h}$. Comparing $\mathrm{C}_{\mathrm{FPA}}$ in medium made with SC (10:90) with 80\% moisture, with the concentration achieved using medium W (100) at $60 \%$ moisture, the increase was $341 \%$. Although the soybean bran price on the Brazilian market is higher than the wheat bran price - US\$412.00/ton and US\$119.00/ton (CORRETORA MERCADO), respectively - half of the mass of the former results in a significantly higher enzyme production.

On the basis of these results, it is possible to conclude that soybean bran is an excellent substrate for cellulase production under high productivities. Sugarcane bagasse is excellent as a cellulase synthesis inducer, besides having a high water retention capacity (Oriol et al., 1988), which is positive for microbial growth. Myceliophtora sp. M77 is an important microorganism for cellulase production as shown by its high sensitivity to induction imposed by cellulose, and, as a thermophilic fungi, it produces thermostable enzymes, as reported by Zanphorlin et al. (2010) when assaying the enzymes of this fungus.

\section{Cellulase concentration and productivity in SSC and SmC}

Published data on cellulase concentration, $\mathrm{C}_{\mathrm{FPA}}(\mathrm{U} / \mathrm{gdm})$, and productivity, $\mathrm{P}_{\mathrm{R}}$ $(\mathrm{U} / \mathrm{gdm} / \mathrm{h})$, in solid and liquid media cultures of some microorganisms, including the data from the present paper, are presented in Table 1. Cellulase concentration in the culture media and productivity are important features for calculating enzyme cost. In order to allow comparisons of $\mathrm{C}_{\mathrm{FPA}}$ and $\mathrm{P}_{\mathrm{R}}$ in solid and liquid media, both were presented as a volumetric concentration, $\mathrm{U} / \mathrm{mL}$, by means of equation 3 , where $u$ is the initial moisture (mass fraction) on a wet basis and $d_{B}$ is the bulk density of the culture medium: 
$C_{F P A}\left(U / m D=C_{F P A}(U / g d m) \cdot(1-u) \cdot d_{B}(g / m D)\right.$ (3)

The huge differences among the cellulase concentrations in SSC, from 4 to 247 $(\mathrm{U} / \mathrm{gdm})$, cannot be explained on the basis of different microorganisms and media if one considers the range of values presented in section 3.1 of this paper. These variations may be due to differences in the filter paper activity measurement, although many authors refer to Ghose et al. (1987) or Mandels et al. (1976). Following the method of Ghose et al. (1987) rigorously, at least two dilutions of the sample with cellulases must be made. Besides, some authors make modifications in the temperature or in the time interval of the reaction (Silva et al. 2005). The lack of a complete standardization of the method impairs free comparisons. Other aspects that deserve consideration are the high values of $\mathrm{C}_{\mathrm{FPA}}$ in SmC and SSC made in 1984 and 1985, $30 \mathrm{U} / \mathrm{mL}$ and $172 \mathrm{U} / \mathrm{gdm}$, respectively. Both results were obtained with $T$. reesei Rut-C30 and are far higher than current values; this makes it reasonable to suppose that there have been mutations in the capacity of this microorganism concerning cellulase production. The instability of filamentous fungi for enzyme production is probably associated with the time interval of 25 years and the different methods of strain preservation (Kilikian et al. 1992).

Medium composition of course influences $\mathrm{C}_{\mathrm{FPA}}$, but it is clear that for one specific microorganism cultivated in some media, over a restricted time interval of stock culture preservation such as a few months, enzyme concentrations will not show large variations as shown by the data presented in Figures 1 to 5 .

Despite the doubts on the accuracy of the reported cellulase concentration values measured using the FPA, it is possible to conclude, based on values reported in the last 10 years, that SSC results in cellulase productivities as high or even higher than in SmC. The data from Dillon et al. (2006), for instance, show productivity in SSC 4.6 times greater than in SmC, for the same microorganism cultivated in the same laboratory, and therefore using the same FPA measurement procedure.

However, these values are not high enough for the economic viability of cellulase production, taking into account that a significant drop in cost has been found with a productivity increase from 50 to $200 \mathrm{U} / \mathrm{L} / \mathrm{h}$ as stated by Himmel et al. (1999). Further 
increases in productivity have a minor impact on enzyme cost. Table 1 shows that a value of $200 \mathrm{U} / \mathrm{L} / \mathrm{h}$ was not reported by any reference; only Hendy et al. (1984) reached a $\mathrm{C}_{\mathrm{FPA}}$ close to this, $180.7 \mathrm{U} / \mathrm{L} / \mathrm{h}$.

Although the data for $\mathrm{C}_{\mathrm{FPA}}$ and $\mathrm{P}_{\mathrm{R}}$ in this paper are lower than in $\mathrm{SmC}$, it is important to note that enzyme activity was always based on measures made in liquid extracts, which probably does not contain the entirety of the enzymes produced using solid media (Rodriguez et al., 2006).

\section{Stability of cellulase activity as a function of culture medium}

In microbial production of enzymes, proteases are frequently synthesized, which can reduce the concentration of the target enzyme. According to Haab et al. (1990), high levels of protease in the extracellular culture environment are correlated with the appearance of products of proteolytic cellulase degradation. The data in Figure 6 illustrate the stability of cellulase as a function of the culture medium composition. The novel microorganism, Myceliophtora sp. M77 cultivated in media with soybean bran was included owing to its good results, while Trichoderma harzianum rifai IPT821 was included owing to the illustrative response to wheat bran. Cellulases of Myceliophtora sp. M77 were stable in both media with $10 \%$ soybean bran, while the increase in $S$ to $20 \%$ resulted in a decrease in $\mathrm{C}_{\mathrm{FPA}}$ from the second day of culture. On the other hand, a medium with $20 \%$ W supported a stable cellulase concentration produced by Trichoderma harzianum rifai IPT821. Owing to the instability of cellulase activity as a result of the action of proteases, the higher protein content in $\mathrm{S}$ relative to $\mathrm{W}$ probably means a higher induction in protease synthesis. Above $20 \% \mathrm{~W}$, which is to say 60,40 and $100 \%$, there was always a significant decrease in cellulase activity, from the second or third day up to the fifth day of culture.

The kinetics of cellulase production were also determined for all other cultures and showed different levels of instability for a given media and microorganism, which means that cellulase stability, depends on the specific strain in addition to medium composition. However, for the best case scenario among the cultures presented in this paper, Myceliophtora sp. M77 on a medium made of SC (10:90) at $80 \%$ moisture, $\mathrm{C}_{\mathrm{FPA}}$ was not only stable, but it continued to increase on the fifth day of culture. 


\section{Conclusions}

Highest FPA, $10.6 \mathrm{U} / \mathrm{gdm}$, was achieved with Myceliophthora sp. M77 on soybean bran (S) and sugarcane bagasse (C), (10:90), initial moisture $80 \%$. This activity was 3.5 times higher than production on pure wheat bran (W). C was a strong inducer of cellulase production, given that the maximum FPA in $\mathrm{W}$ and $C(40: 60), 6.1 \mathrm{U} / \mathrm{gdm}$, was 2.5 times higher than pure W. T. reesei Rut-C30 did not respond as strongly, with a 1.6fold surplus production. $S$ advantageously replaced $W$, as the surplus production on $S$ and $C(20: 80)$ was 2.3 times relative to $W$ and $C(20: 80)$ for M77.

\section{Acknowledgements}

The authors greatly acknowledge the financial grant for this research provided by the Brazilian National Council of Scientific and Technological Development (CNPq), the Coordination for the Improvement of Higher Education Personnel (CAPES) and the Studies and Projects Funder Agency (FINEP). We thank Dr. Eleni Gomes from UNESP (SP/BRAZIL) for providing the fungus Myceliophtora sp. and Dr. Maria Filomena de Andrade Rodrigues from IPT (SP/BRAZIL) for providing Trichoderma sp. IPT778 and Trichoderma harzianum rifai IPT821.

\section{References}

Awafo, V.A., Chahal, D.S., Simpson, B.K. (2000) Evaluation of combination treatments of sodium hydroxide and steam explosion for the production of cellulase-systems by two T. reesei mutants under solid-state fermentation conditions. Bioresour. Technol., 73, 235-245.

Bozell, J.J., Petersen, G.R. (2010) Technology development for the production of biobased products from biorefinery carbohydrates-the US Department of Energy's "Top 10" revised. Green Chem., 12, 539-554. 
Brijwani, K., Oberoi, H.S., Vadlani, P.V. (2010) Production of a cellulolytic enzyme system in mixed-culture solid-state fermentation of soybean hulls supplemented with wheat bran. Process Biochem., 45, 120-128.

Cen, P., Xia, L. (1999) Production of cellulase by solid-state fermentation. Adv. Biochem. Eng./ Biotechnol., 65, 69-92.

Chahal, D.S.(1985) Solid-State Fermentation with Trichoderma reesei for Cellulase production. Appl. Environ. Microbiol., 49 (1), 205-210.

Corretora Mercado. http://www.clicmercado.com.br/novo/website/index.asp. Last acessed: April, 2011.

Dillon, A.J.P., Zorgi, C., Camassola, M., Henriques, J.A.P. (2006) Use of 2deoxyglucose in liquid media for the selection of mutant strains of Penicillium echinulatum producing increased cellulose and $\beta$-glucosidase activities. Appl. Microbiol. Biotechnol., 70, 740-746.

Galbe, M., Sassner, P., Wingren, A., Zacchi, G., (2007) Process engineering economics of bioethanol production, in: Olssen, L., Biofuels. Springer Berlin/Heidelberg, 303-328.

Gamarra, N.N., Villena, G.K., Gutiérrez-Correa, M. (2010) Cellulase production by Aspergillus niger in biofilm, solid-state, and submerged fermentations. Appl. Microbiol. Biotechnol., 87, 545-551.

Ghose, T.K. (1987) Measurement of cellulase activities. Pure Appl. Chem., 59, 257-268.

Haab, D., Hagspiel, K., Szakmary, K., Kubicek, C.P. (1990) Formation of the extracellular proteases from Trichoderma reesei QM 9414 involved in cellulase degradation. J. Biotechnol., 16 (3-4), 187-198. 
Hendy, N.; Wilke, C.; Blanch, H. (1984) Enhanced cellulase production using solka floc in a fed-batch fermentation. Biotechnol. Lett., 6, 667-672.

Himmel, M.E., Ruth, M.F., Wymans, C.E. (1999) Cellulase for commodity products from cellulosic biomass. Curr. Opin. Biotechnol., 10, 358-364.

Kilikian, B.V., Facciotti, M.C.R., Schimidell Netto, W. (1992) Analysis of the kinetic pattern of glucoamylase production regarding the Aspergillus awamori preservation time. Rev. Microbiol., 23 (2),123-127.

Krishna, C. (2005) Solid-State Fermentation Systems - An Overview. Crit. Rev. Biotechnol., 25, 1-30.

Mandels, M., Andreotti, R., Roche, C. (1976) Measurement of saccharifying cellulase. Biotechnol. Bioeng. Symp., 6, 21-33.

Mekala, N. K., Singhania, R.R., Sukumaran, R. K., Pandey, A. (2008) Cellulase Production Under Solid-State Fermentation by Trichoderma reesei RUT C30: Statistical Optimization of Process Parameters. Appl. Biochem. Biotechnol., 151, 122-131.

Oriol, E., Raimbault, M., Roussos, S., Viniegra-Gonzales, G. (1988) Water and water activity in the solid state fermentation of cassava starch by Aspergillus niger. Appl. Microbiol. Biotechnol., 27, 498-503.

Raimbault, M. (1998). General and microbiological aspects of solid substrate fermentation. Elec. J. Biotechnol., 1, 174-188.

Rodriguez, J.A., Mateos, J.C., Nungaray, J., Gonzalez, V., Bhagnagar, T., Roussos, S., Cordova, J., Baratti, J. (2006) Improving lipase production by nutrient source modification using Rhizopus homothallicus cultured in solid state fermentation. Process Biochem., 4, 2264-2269. 
Roussos, S. Raimbault, M. Viniegra-González, G. Saucedo-Castañeda, G. Lonsane, B. K. (1991) Scale-up of cellulases production by Trichoderma harzianum on a mixture of sugar cane bagasse and wheat bran in solid state fermentation system. Micol. Neotrop. Appl., 4, 83-98.

Silva, R. Lago, E.S., Merheb, C. W. Macchione, M.M. Park, Y.K., Gomes, E. (2005) Production of xylanase and CMCase on solid state fermentation in different residues by Thermoascus Aurantiacus Miehe. Braz. J. Microbiol., 36, 235-241.

Sun, X., Liu, Z., Qu, Y.,Li, X. (2008) The Effects of Wheat Bran Composition on the Production of Biomass-Hydrolyzing Enzymes by Penicillium decumbens. Appl. Biochem. Biotechnol., 146 (1-3), 119-28.

Tangnu, S.K., Blanch, H.B., Wilke, C.R. (1981) Enhanced Production of Cellulase, Hemicellulase, and beta-Glucosidase by Trichoderma reesei (Rut C-30). Biotechnol. Bioeng., 23, 1837-1849.

Urbanszki, K., Szakacs, G., Tengerdy, R.P. (2000) Standardization of the filter paper activity assay for solid substrate fermentation. Biotechnol. Lett., 22 (1), 65-69.

Zanphorlin, L.M., Facchini, F.A., Vasconcelos, F., Bonugli-Santos, R.C., Rodrigues, A., Sette, L.D., Gomes, E., Bonilla-Rodriguez, G.O. (2010) Production, Partial Characterization, and Immobilization in Alginate Beads of an Alkaline Protease from a New Thermophilic Fungus Myceliophthora sp. J. Microbiol., 48(3), 331-336. 
Table 1: Concentration and productivity of cellulases in SSC and SmC for some fungi.

\begin{tabular}{|c|c|c|c|c|c|}
\hline Microorganism & $\begin{array}{c}\mathrm{C}_{\mathrm{FPA}} \\
(\mathrm{U} / \mathrm{gdm})\end{array}$ & $\begin{array}{l}\text { Bulk Density* } \\
\quad(\mathrm{g} / \mathrm{mL})\end{array}$ & $\begin{array}{c}\mathrm{C}_{\mathrm{FPA}} \\
(\mathrm{U} / \mathrm{mL})\end{array}$ & $\begin{array}{c}\mathrm{P}_{\mathrm{R}} \\
(\mathrm{U} / \mathrm{L} / \mathrm{h})\end{array}$ & Reference \\
\hline \multicolumn{6}{|c|}{ SOLID STATE CULTURES } \\
\hline T. reesei Rut-C30 & 4.0 & 0.6 & 1.0 & 8.6 & data from this article \\
\hline Myceliophthora sp. M77 & 10.6 & 0.9 & 1.9 & 15.8 & data from this article \\
\hline T. reesei QMY-1 & 247 & ---- & ---- & ---- & Awafo et al. (2000) \\
\hline T. reesei Rut-C30 & 24.15 & 0.7 & 4.9 & 74.1 & Mekala et al. (2008) \\
\hline Penicillium echinulatum 9A02D1 & 22.4 & 0.7 & 5.6 & 77.6 & Dillon et al. (2006) \\
\hline T. reesei Rut-C30 & 172 & 0.8 & 28 & 53.0 & Chahal (1985) \\
\hline \multicolumn{6}{|c|}{ SUBMERGED CULTURES } \\
\hline Aspergillus niger & $\begin{array}{ll}--- \\
\end{array}$ & $\begin{array}{ll}--- \\
\end{array}$ & 1.2 & 16.2 & Gamarra et al. (2010) \\
\hline Penicillium echinulatum 9A02S1 & ---- & ---- & 2.0 & 16.7 & Dillon et al. (2006) \\
\hline Thichoderma reesei (Rut-C30) & ---- & ---- & 14.4 & 80.0 & Tangnu et al. (1981) \\
\hline Thichoderma reesei (Rut-C30) & --- & ---- & 30 & 180.7 & Hendy et al. (1984) \\
\hline
\end{tabular}

* The bulk density of each medium reported in the articles was measured in our laboratory. As it was not possible to reproduce the exact medium used by other authors, the density may be considered as only an approximate value used to calculate the productivity in $\mathrm{U} / \mathrm{L} / \mathrm{h}$. 


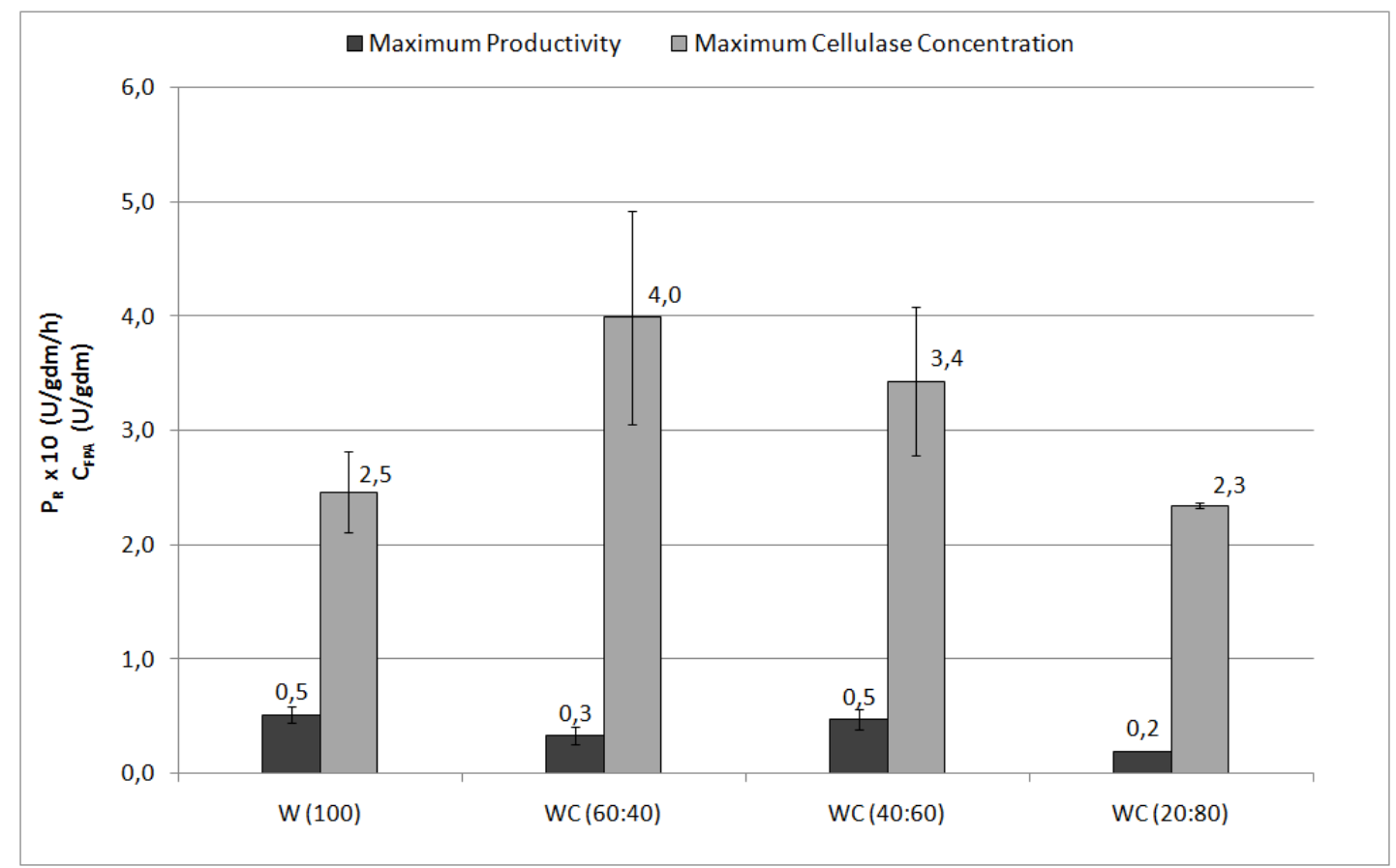

Fig. 1. Maximum Productivity $(x 10), P_{R}$, and Maximum Cellulase Concentration, $C_{F P A}$, for Trichoderma reesei Rut-C30 cultivated on solid state media made of wheat bran, $\mathrm{W}$, and sugarcane bagasse, $\mathrm{C}$, at $60 \%$ moisture on a wet basis. 


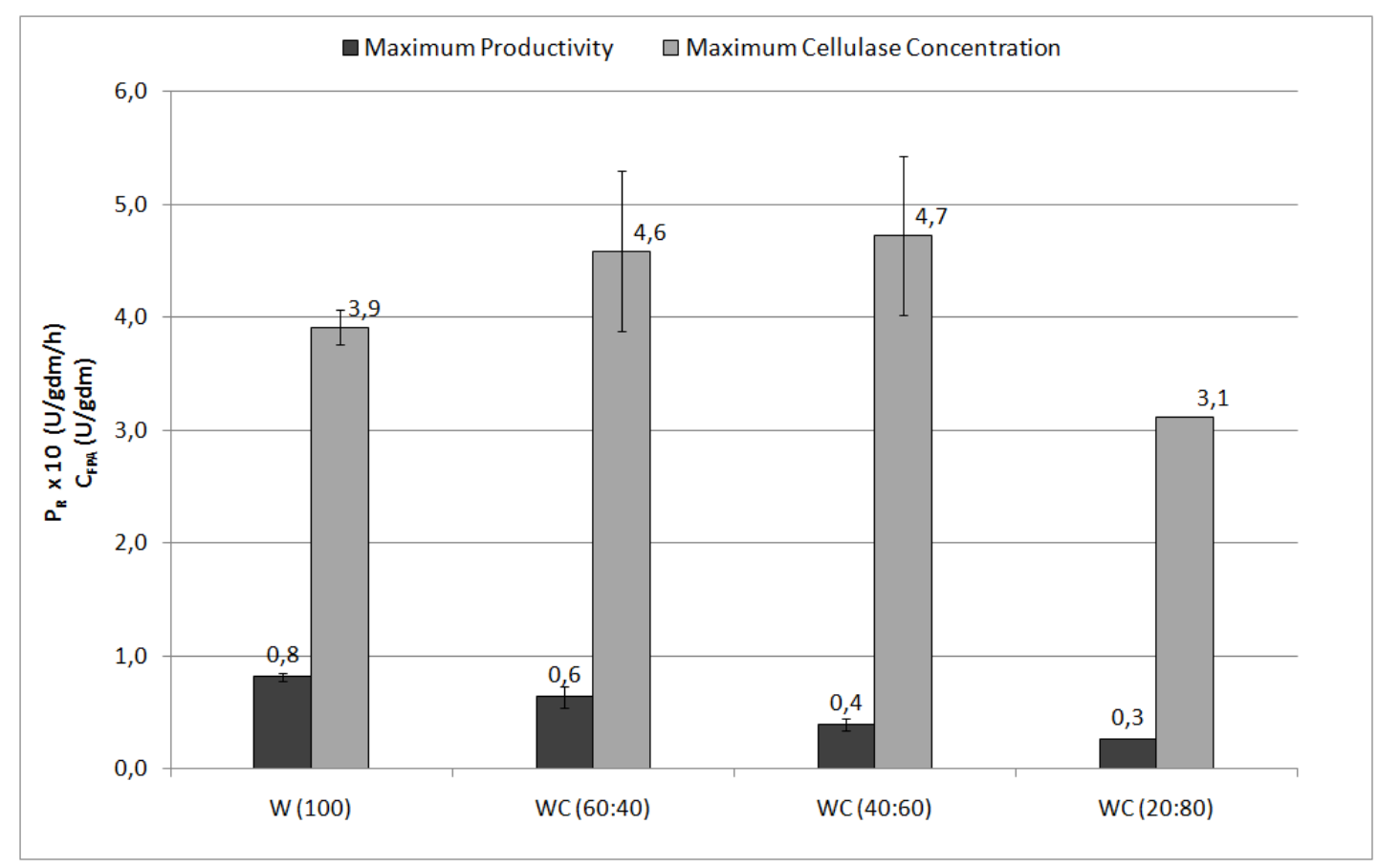

Fig. 2. Maximum Productivity $(x 10), P_{R}$, and Maximum Cellulase Concentration, $C_{F P A}$, for Trichoderma reesei QM9414 cultivated on solid state media made of wheat bran, W, and sugarcane bagasse, $\mathrm{C}$, at $60 \%$ moisture on a wet basis. 


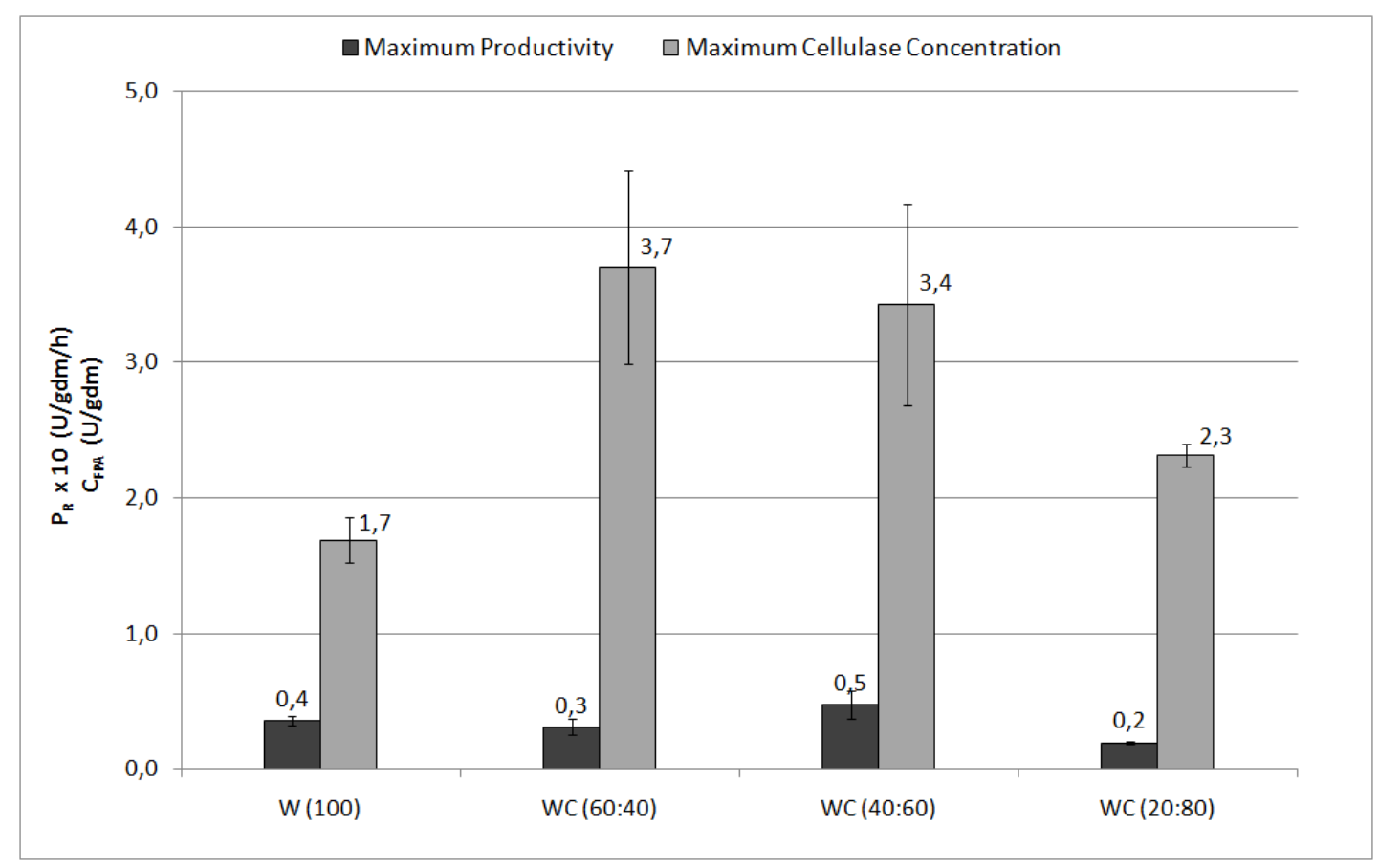

Fig. 3. Maximum Productivity $(x 10), P_{R}$, and Maximum Cellulase Concentration, $C_{F P A}$, for Trichoderma sp. IPT778 cultivated on solid state media made of wheat bran, W, and sugarcane bagasse, $\mathrm{C}$, at $60 \%$ moisture on a wet basis. 


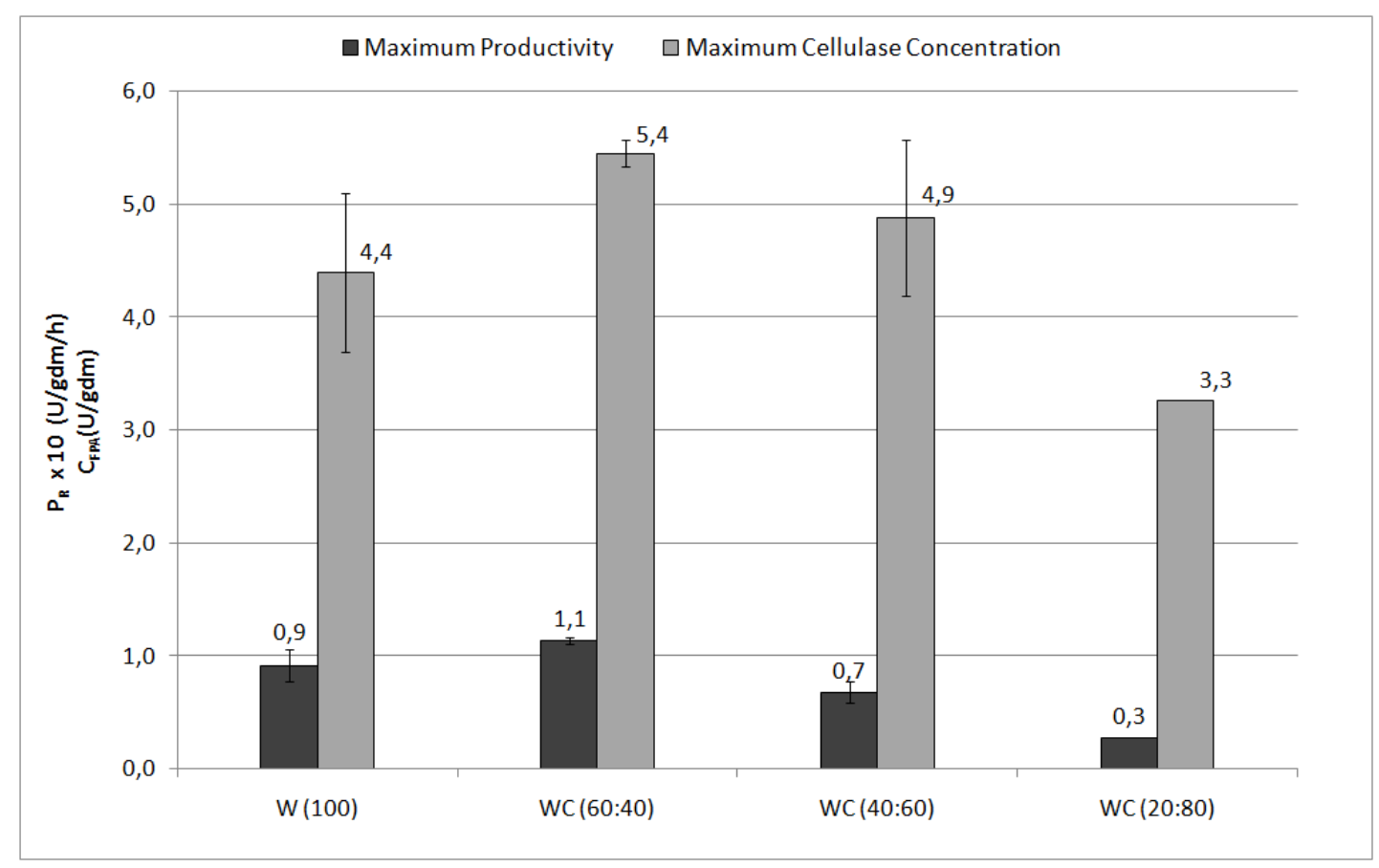

Fig. 4. Maximum Productivity $(x 10), P_{R}$, and Maximum Cellulase Concentration, $C_{F P A}$, for Trichoderma harzianum rifai IPT821 cultivated on solid state media made of wheat bran, $\mathrm{W}$, and sugarcane bagasse, $\mathrm{C}$, at $60 \%$ moisture on a wet basis. 


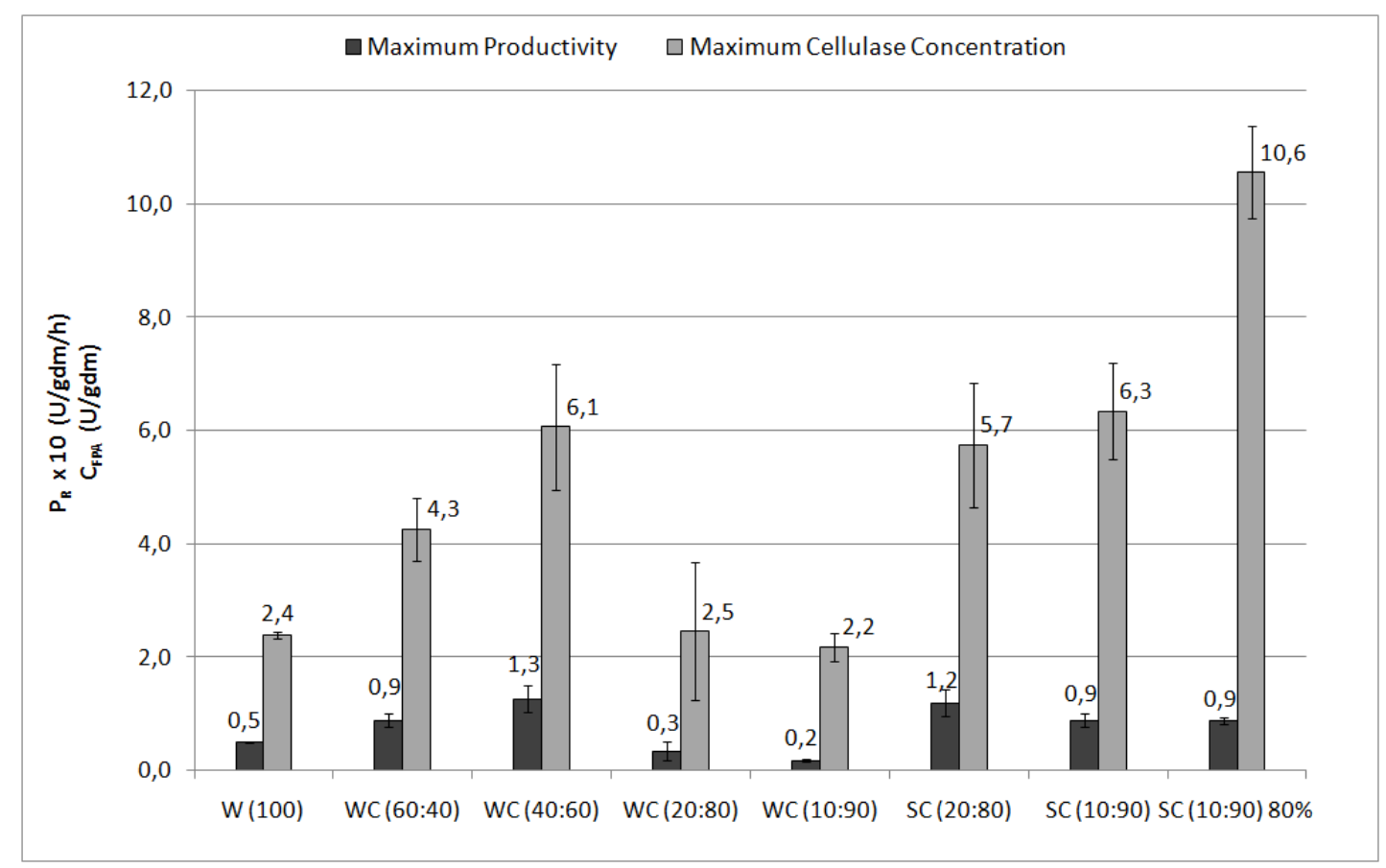

Fig. 5. Maximum Productivity (x10), $P_{R}$, and Maximum Cellulase Concentration, $C_{F P A}$, for Myceliophtora sp. M77 cultivated on solid state media made of wheat bran, W, sugarcane bagasse, C, and soybean bran, S, at 60\% moisture, except for the last assay which was done at $80 \%$ moisture on a wet basis, as indicated. 


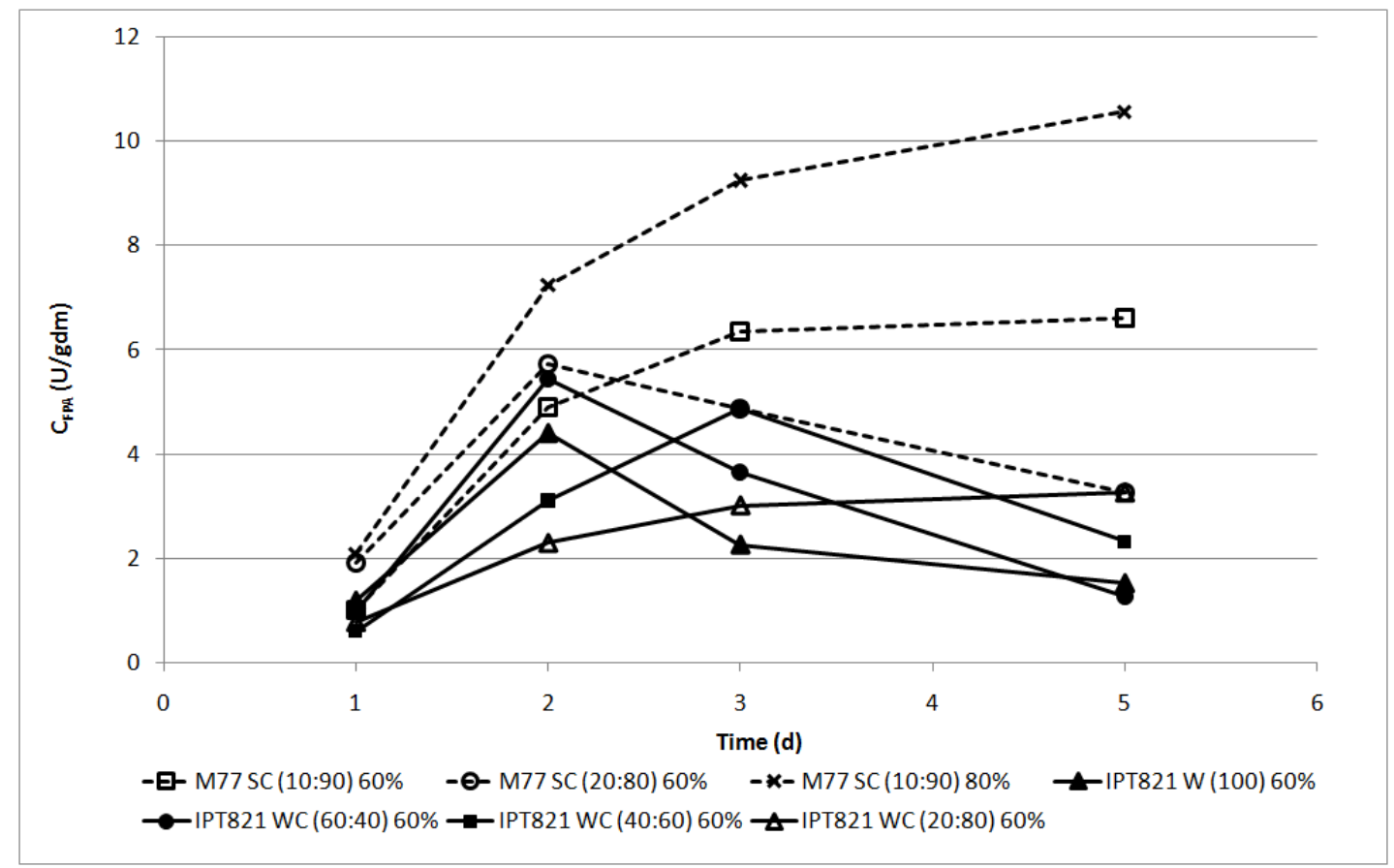

Fig. 6. Time course of cellulase concentration, $\mathrm{C}_{\mathrm{FPA}}$, for Myceliophtora sp. M77 and Trichoderma harzianum rifai IPT821 in SSC made of soybean bran and sugar cane bagasse or wheat bran and sugar cane bagasse, at 60 or $80 \%$ moisture on a wet basis. 